UNIVERSIDADE DE SÃO PAULO

FACULDADE DE ECONOMIA, ADMINISTRAÇÃO E CONTABILIDADE DEPARTAMENTO DE ADMINISTRAÇÃO PROGRAMA DE PÓS-GRADUAÇÃO EM ADMINISTRAÇÃO

O VALOR PERCEBIDO DE LOJA PELOS CLIENTES, NA PERSPECTIVA DOS BENEFÍCIOS, COMO ANTECEDENTE DE SUA LEALDADE À LOJA.

Francisco Claudio Melo dos Santos.

Orientador: Prof. Dr. Celso Cláudio de Hildebrand e Grisi.

SÃO PAULO 
Prof. Dr. Marco Antônio Zago

Reitor da Universidade de São Paulo

Prof. Dr. Adalberto Américo Fischmann

Diretor da Faculdade de Economia, Administração e Contabilidade

Prof. Dr. Roberto Sbragia

Chefe do Departamento de Administração

Prof. Dr. Moacir de Miranda Oliveira Júnior

Coordenador do Programa de Pós-Graduação em Administração 


\section{O VALOR PERCEBIDO DE LOJA PELOS CLIENTES, NA PERSPECTIVA DOS BENEFÍCIOS, COMO ANTECEDENTE DE SUA LEALDADE À LOJA.}

Tese de Doutorado apresentada ao Programa de Pós-Graduação em Administração do Departamento de Administração da Faculdade de Economia, Administração e Contabilidade da Universidade de São Paulo como parte dos requisitos para a obtenção do título de Doutor em Ciências.

Orientador: Prof. Dr. Celso Cláudio de Hildebrand e Grisi

\section{Versão Corrigida}

(versão original disponível na Biblioteca da Faculdade de Economia, Administração e Contabilidade)

\section{SÃO PAULO}



FICHA CATALOGRÁFICA

Elaborada pela Seção de Processamento Técnico do SBD/FEA/USP

Santos, Francisco Claudio Melo dos

O valor percebido de loja pelos clientes, na perspectiva dos benefícios, como antecedente de sua lealdade à loja / Francisco Claudio Melo dos Santos. - São Paulo, 2016.

$130 \mathrm{p}$.

Tese (Doutorado) - Universidade de São Paulo, 2016.

Orientador: Celso Cláudio de Hildbrand e Grisi.

1. Marketing 2. Varejo 3. Valor percebido I. Universidade de São Paulo. Faculdade de Economia, Administração e Contabilidade.

II. Título.

$\mathrm{CDD}-658.8$ 
A meus pais

Miguel Rodrigues e Maria Aparecida, e à minha esposa Maria Euni que me propiciaram o maior valor percebido em minha vida: a dignidade da educação. 
Agradeço ao professor e orientador Celso Cláudio de Hildebrand e Grisi, pelo apoio e encorajamento contínuos na pesquisa, aos demais mestres da casa, pelos conhecimentos transmitidos, e à FEA USP, pelo apoio institucional e pelas facilidades oferecidas.

À minha família e esposa pelo incansável apoio, mesmo nos momentos em que buscávamos forças, juntos, para superar obstáculos que nos pareciam instransponíveis.

A todos os entrevistados, tanto na fase de pré-teste quanto na etapa efetiva da coleta dos dados, que mostraram grande desprendimento ao cederem parte de seu tempo para ajudar na realização deste trabalho acadêmico.

Aos funcionários da seção de pós-graduação: Maria Aparecida de Jesus Sales, Ana Paula Rodrigues Alves, Adriana da Silva Munuera Molina, Francisco Oliveira Costa e Carlos Roberto de Assunção, por sua dedicação e empenho na resolução de nossos problemas acadêmicos, e por sua inigualável empatia conosco.

À Patrícia Maldonado, analista de educação da ABRASCE (Associação Brasileira de Shopping Centers) por fornecer os dados sobre a participação econômica das lojas em shoppings para que esta pesquisa pudesse ser ricamente ilustrada. 
"Money is a great servant but a bad master". "O dinheiro é um grande servo, mas um péssimo patrão" 


\section{RESUMO}

O shopping center ainda é, sem dúvida nenhuma, um local atraente para os clientes realizarem suas compras. O mix de lojas presentes neste modal varejista, responsável pela oferta de serviços como estacionamento, entretenimento, alimentação, além de uma gama interminável de todo tipo de mercadoria que se possa imaginar, é o responsável por atrair, todos os dias, milhares de clientes para seu interior. Não obstante todas essas facilidades, os lojistas de shopping centers estão enfrentando uma forte concorrência de outros modais varejistas como as vendas diretas (por meio de demonstradores), as compras eletrônicas; a venda automática (por meio das máquinas de venda) e os serviços de compras (varejo sem loja que atende a clientes específicos). Em função disso, este trabalho propôs-se a discutir como as lojas poderiam atrair uma maior atenção de seus clientes por intermédio do valor percebido por eles. Este valor, sob a perspectiva do benefício, deriva da avaliação global do cliente quanto às vantagens que ele ganha ao ponderar os benefícios e os sacrifícios percebidos quando adquire produtos. Tais sacrifícios podem ser de ordem não monetária (custos de transação, pesquisa, negociação, tempo incorrido na aquisição do produto etc.). Também se estudou o impacto deste valor na fidelização do cliente a certa loja. Após extensa consulta bibliográfica sobre os conceitos apresentados, adotou-se a metodologia do Discurso do Sujeito Coletivo (DSC) para se analisar os resultados obtidos na coleta dos dados por meio de entrevista com clientes fiéis de lojas situadas em shoppings. O DSC apoia-se na teoria da representação social, de Jodelet, segundo a qual grupos sociais específicos compartilham ideias e valores comuns em um dado momento. Ele busca, portanto, estabelecer um caminho sistemático para descobrir estas representações sociais destes grupos específicos no que tange aos temas propostos. Os resultados apresentados revelaram que o ambiente da loja e sua imagem influenciaram, muito positivamente, a percepção dos clientes como atributos importantes para se gerar valor percebido, enquanto o prestígio e o local onde a loja está situada dentro do shopping foram avaliados por eles como características medianamente influenciadoras neste sentido. Além disso, verificou-se que o valor percebido pelo cliente influencia, positivamente, em sua decisão de se tornar fiel a determinada loja. No final, foram lembradas ações de marketing que poderiam ser desenvolvidas pelos gestores de loja a fim de alavancarem o valor de loja percebido pelo cliente, na perspectiva dos benefícios, vital à sua fidelização. 


\begin{abstract}
The shopping mall is also, undoubtedly, an attractive location for customers to conduct their purchases. The mix of shops present in this retailer modal, responsible for the provision of services such as parking, entertainment, food, and an endless array of all kinds of unimaginable merchandises, is responsible for attracting, every day, thousands of customers to inside the mall. Despite all these easinesses, shopping center tenants are facing strong competition from other retailers modal as direct sales (through demonstrators), electronic shopping; automatic sale (through vending machines) and shopping services (retail without store that caters to specific customers). As a result, this study aimed to discuss how the stores could attract more attention of their customers through the non-monetary value perceived by them. This value, from the perspective of benefits, derives from the overall assessment of the client as to the advantages that he gets to weigh the benefits and perceived sacrifices when he purchase products. Such sacrifices may be non-monetary order (transaction costs, search, negotiation, time incurred in acquiring the product etc.). This Thesis also studied the impact of this value in the loyalty of the customer towards the certain store. After extensive bibliographical research on the concepts presented, we adopted the Collective Subject Discourse methodology (CSD) to analyze the results obtained in data collection through interviews with loyal customers of stores located in malls. The CSD is based on the theory of social representation, from Jodelet, according to which specific social groups share common ideas and values at a given time. It seeks therefore to establish a systematic way to discover these social representations of these specific groups regarding the proposed themes. The presented results show that the store environment and its image influenced very positively the perception of the customer as important attributes to generate non-monetary perceived value, while the prestige and the place where the store is located inside the mall were evaluated by them as moderately influential features in this regard. In addition, it was found that the nonmonetary perceived value by the customer influences positively in his decision to become loyal to a particular store. In the end, marketing actions were reminded that could be carried out by store managers to promote the non-monetary perceived value by the customers, vital to their loyalty.
\end{abstract}




\begin{tabular}{|c|c|c|}
\hline & & \\
\hline & & \\
\hline QUE & & DRÃO DE LISTA DE TABELAS. \\
\hline SQUE & V & DRÃO DE LISTA DE GRÁFICOS.................. \\
\hline ESQUEN & & ADRÃO DE LISTA DE FIGURAS..................... \\
\hline IN & & ODUÇÃO \\
\hline 1.1 & & lema de pesquisa \\
\hline 1.2 & & tivos da pesquisa ............................... \\
\hline 1.3 & & icativa para a realização do estudo.. \\
\hline 2 & & ÇÃO TEÓRICA. \\
\hline 2.1 & & hopping centers....................... \\
\hline 2.2 & & aldade à loja. \\
\hline 2.3 & & percebido de loja pelo cliente na perspectiva dos benefícios. \\
\hline 2.4 & & ................................... 23 \\
\hline 2.4.1 & & Fatores ambientais: \\
\hline 2.4.1. & & - \\
\hline 2.4.2 & & . \\
\hline 2.4.2. & & 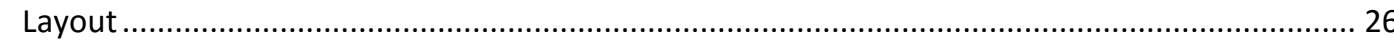 \\
\hline 2.4.2. & & Disponibilidade de mercadoria na loja.. \\
\hline 2.4 .3 & & Fatores sociais: ....... \\
\hline 2.4.3. & & dos vendedores na loja..................... \\
\hline 2.5 & & 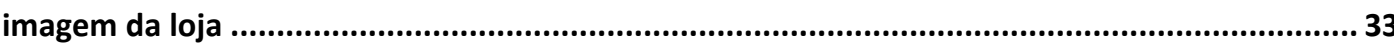 \\
\hline 2.6 & & gio da loja....................................... \\
\hline 2.7 & & 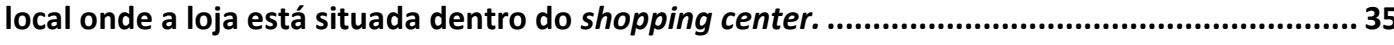 \\
\hline & & ODOLOGIA DA PESQUIS \\
\hline 3.1 & & 39 \\
\hline 3.2 & & vo \\
\hline 3.3 & & 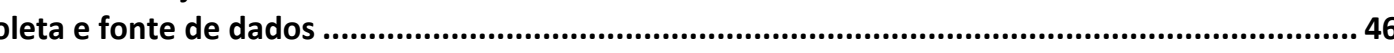 \\
\hline 3.3.1 & & descrição dos respondentes. \\
\hline 3.4 & & 51 \\
\hline 3.5 & & nálise dos dados \\
\hline 3.6 & & 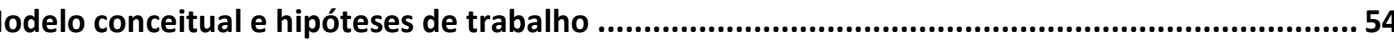 \\
\hline 3.6.1 & & evante para sua fidelização à loja. .......................... 54 \\
\hline 3.6.2 & & te. ........................... 55 \\
\hline 3.6.3 & & A ima \\
\hline 3.6.4 & & do pelo cliente. ............................. 58 \\
\hline $\begin{array}{l}3.6 .5 \\
\text { client }\end{array}$ & & $\begin{array}{l}\text { O local onde a loja está situada dentro do shopping como meio de agregação de valor para o } \\
59\end{array}$ \\
\hline Al & & E DOS RESULTADOS ......... \\
\hline $\mathrm{CC}$ & & USÕES. \\
\hline DI & & USSÕES E IMPLICAÇÕES GERENCIAIS... \\
\hline & ON & SIDERAÇÕES FINAIS .. \\
\hline 7.1 & & . \\
\hline 7.2 & & ugestões para pesquisas futuras. \\
\hline REFE & & .105 \\
\hline GLOSS & & $\ldots \ldots \ldots \ldots \ldots . . . . . . . .114$ \\
\hline APÊND & &. .115 \\
\hline ROTEIRC & & E ENTREVISTA .... \\
\hline TEXTO $\mathrm{P}$ & & RÃO DE E-MAIL ENVIADO PARA OS POTENCIAIS RESPONDENTES...... \\
\hline ANEXC & & $\ldots 118$ \\
\hline & & \\
\hline
\end{tabular}




\section{ESQUEMA PADRÃO DE LISTA DE QUADROS}

Quadro 1: Características dos paradigmas qualitativo e quantitativo. .................................. 40

Quadro 2: Contínuo da estrutura de formalidade da entrevista............................................... 46

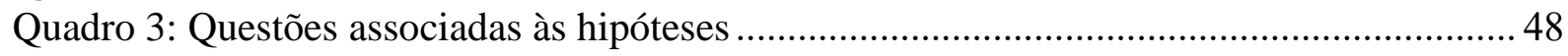

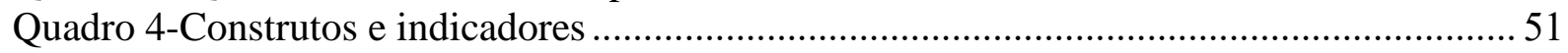




\section{ESQUEMA PADRÃO DE LISTA DE TABELAS}

Tabela 1- Índice do desempenho dos shoppings no Brasil- dezembro/2014 ........................... 7

Tabela 2- Número de lojas em shopping centers no Brasil ................................................... 9

Tabela 3: Participação das lojas por segmento nos shopping centers no Brasil (em unidades)

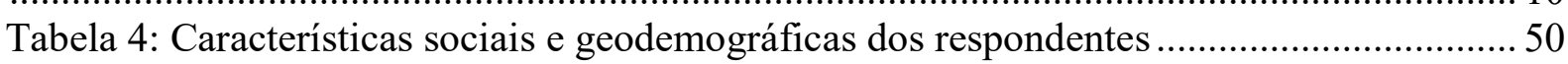

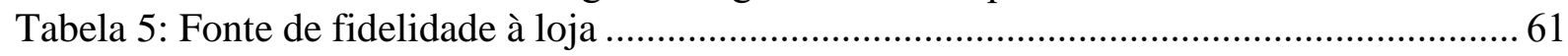

Tabela 6: A música ambiente como forma de agregar valor para o cliente. ............................ 64

Tabela 7: a música ambiente como forma de agregar valor para o cliente. ............................ 67

Tabela 8: o layout como forma de agregar valor para o cliente............................................ 70

Tabela 9: a disponibilidade de mercadoria como forma de agregar valor para o cliente......... 72

Tabela 10: a presença dos vendedores como forma de agregar valor para os clientes ............ 74

Tabela 11: a imagem da loja como forma de agregar valor para o cliente. ............................. 78

Tabela 12: o prestígio da loja como forma de agregar valor para o cliente ............................. 80

Tabela 13: o local onde a loja está situada dentro do shopping como forma de agregar valor

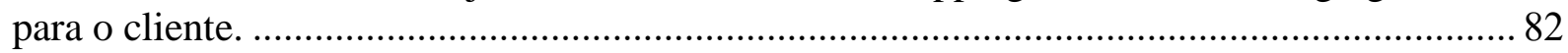

Tabela 14: o valor percebido pelo cliente como antecedente de sua fidelização à loja. .......... 85 


\section{ESQUEMA PADRÃO DE LISTA DE GRÁFICOS}

Gráfico 1- Evolução da ABL em shopping centers no Brasil (em milhões m²) 
Figura 1: Principais motivos para se ir ao shopping (2014) ...................................... 8

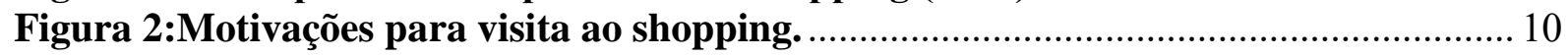

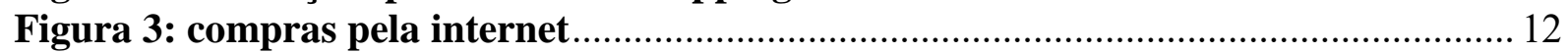

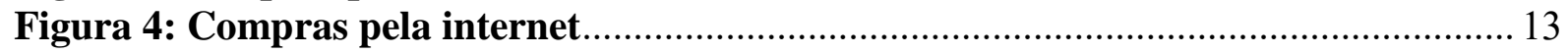

Figura 5- Um quadro integrativo dos efeitos do ambiente de loja................................ 25

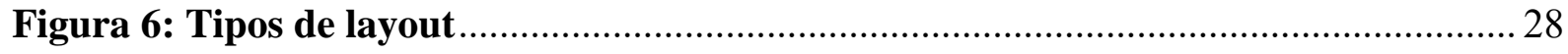

Figura 7: Dimensões da orientação para o cliente pelo vendedor em um encontro de

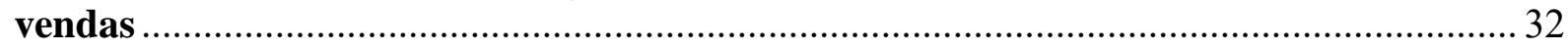

Figura 8: modelo conceitual e hipótese de trabalho ...................................................... 54 


\section{INTRODUÇÃO.}

Nas economias contemporâneas, os shopping centers, há muito, converteram-se em uma das principais modalidades de varejo no mundo. Um espaço planejado para que as pessoas possam encontrar, em um só local, ampla gama de bens e serviços, desde vestuários, eletroeletrônicos, commodities até serviços de alimentação, saúde etc. A indústria de shopping centers, no Brasil, vem crescendo significativamente: de acordo com a ABRASCE (Associação Brasileira de Shopping Centers): conforme se pode apurar na tabela 1, este setor, no Brasil, obteve um faturamento da ordem de R\$ 142,28 bilhões em 2014, cerca de 10,1\% acima do índice de 2013. A expectativa para 2015 é de um aumento de 8,5\% nas vendas em relação ao ano anterior. São, aproximadamente, 978.963 pessoas trabalhando em shoppings em nosso país.

Tabela 1- Índice do desempenho dos shoppings no Brasil- dezembro/2014

Faturamento Estimado 2014 (Em R\$ bilhões)

Vendas em Relação ao Varejo Nacional em 2014

Tráfego de Pessoas (milhões por mês)

Empregos diretos em shoppings (mil)

Fonte: Abrasce (2015).

\footnotetext{
${ }^{1}$ Exclui vendas de combustíveis e GLP. Critério: consideram-se aqui shoppings com lojas locadas, lojas âncoras e vagas de estacionamento, com área igual ou superior a $5.000 \mathrm{~m}^{2}$. A informação sobre faturamento é estimada e pode ser alterada.
} 
Dentro deste contexto, as lojas dentro dos shopping centers exercem um papel preponderante na medida em que são elas efetivamente que vão disponibilizar toda a gama de bens e serviços aos clientes potenciais que visitam o shopping. Aliás, conforme pode se observar na figura 1, fazer compras surge como o primeiro motivo para se ir ao shopping, de acordo com a ABRASCE (2015), após entrevistas com 3749 clientes de shoppings das cidades de Brasília, Salvador, Porto Alegre, Belo Horizonte, Rio de Janeiro, São Paulo, Belém, S. J. Campos Interior de São Paulo, realizadas no ano de 2014 e divulgadas em 2015.

Figura 1: Principais motivos para se ir ao shopping (2014)

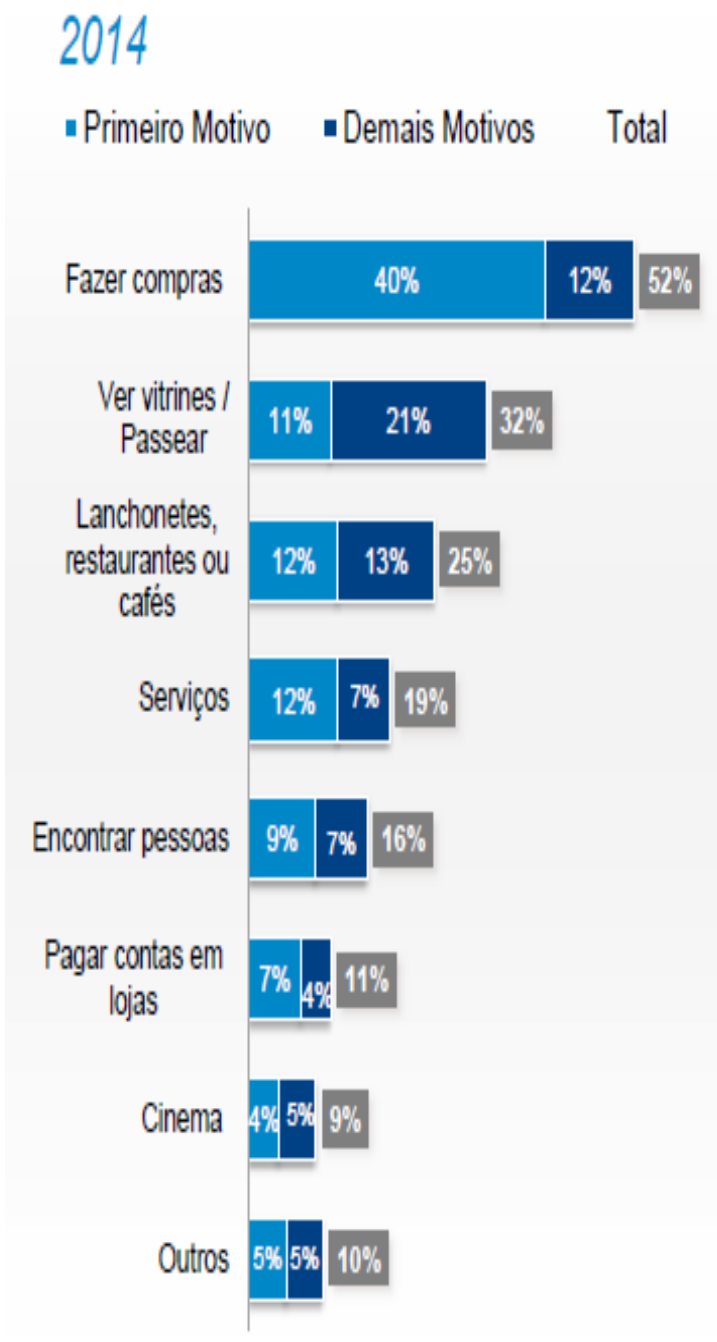

Fonte: Abrasce (2015). 
Nos estudos sobre o desempenho de lojas dentro de shopping centers, de acordo com a Associação Brasileira de Lojistas de Shopping (ALSHOP), vê-se um nítido aumento da participação destes varejistas na tabela 2 abaixo, referente ao período que vai de 2004 a 2014, ressaltando a importância dos lojistas de shoppings no segmento do varejo.

Tabela 2- Número de lojas em shopping centers no Brasil

\begin{tabular}{|c|c|c|c|}
\hline Anos & Quantidade lojas & \multicolumn{2}{|c|}{ Variação Anual } \\
\hline 2004 & 71.769 & 3.153 & \\
\hline 2005 & 74.922 & 2.000 & $4,39 \%$ \\
\hline 2006 & 76.922 & 3.497 & $2,67 \%$ \\
\hline 2007 & 80.419 & 4.647 & $4,55 \%$ \\
\hline 2008 & 85.066 & 9.252 & $5,78 \%$ \\
\hline 2009 & 94.318 & 4.930 & $10,88 \%$ \\
\hline 2010 & 99.248 & 7.900 & $5,23 \%$ \\
\hline 2011 & 107.148 & 6.200 & $7,96 \%$ \\
\hline 2012 & 113.348 & 16.552 & $5,79 \%$ \\
\hline 2013 & 129.900 & 8.796 & $14,60 \%$ \\
\hline 2014 & 138.696 & - & $6,77 \%$ \\
\hline
\end{tabular}

Fonte: Alshop (2015).

As lojas nos shopping centers são, na tipologia da ABRASCE, sobretudo, satélites, ou seja, pequenas, sem aspectos estruturais e mercadológicos especiais, localizadas, geralmente, próximas às âncoras e voltadas ao comércio em geral. São seguidas, muito depois, pelas lojas situadas nas praças de alimentação, e lojas de pequenos serviços, como chaveiros, reparos de roupas e calçados etc., conforme se pode ver na tabela 3 , abaixo. 
Tabela 3: Participação das lojas por segmento nos shopping centers no Brasil (em unidades)

\begin{tabular}{|c|c|c|}
\hline Total de Lojas & 100.707 & $100 \%$ \\
\hline Lojas Âncoras & 3.021 & $3 \%$ \\
\hline Megalojas & 2.014 & $2 \%$ \\
\hline Lojas Satélites & 74.523 & $74 \%$ \\
\hline Lazer & 1.007 & $1 \%$ \\
\hline Alimentação & 13.092 & $13 \%$ \\
\hline Lojas de Serviços & 7.050 & $7 \%$ \\
\hline
\end{tabular}

Fonte: Abrasce (2015).

As lojas Âncoras, apesar de representarem somente 3\% do total do mix de lojas presentes nos shopping centers, ainda têm um forte poder de atração dos clientes para esta modalidade de varejo, conforme pode se notar na figura 2, referente ao período de 2014.

Figura 2:Motivações para visita ao shopping.
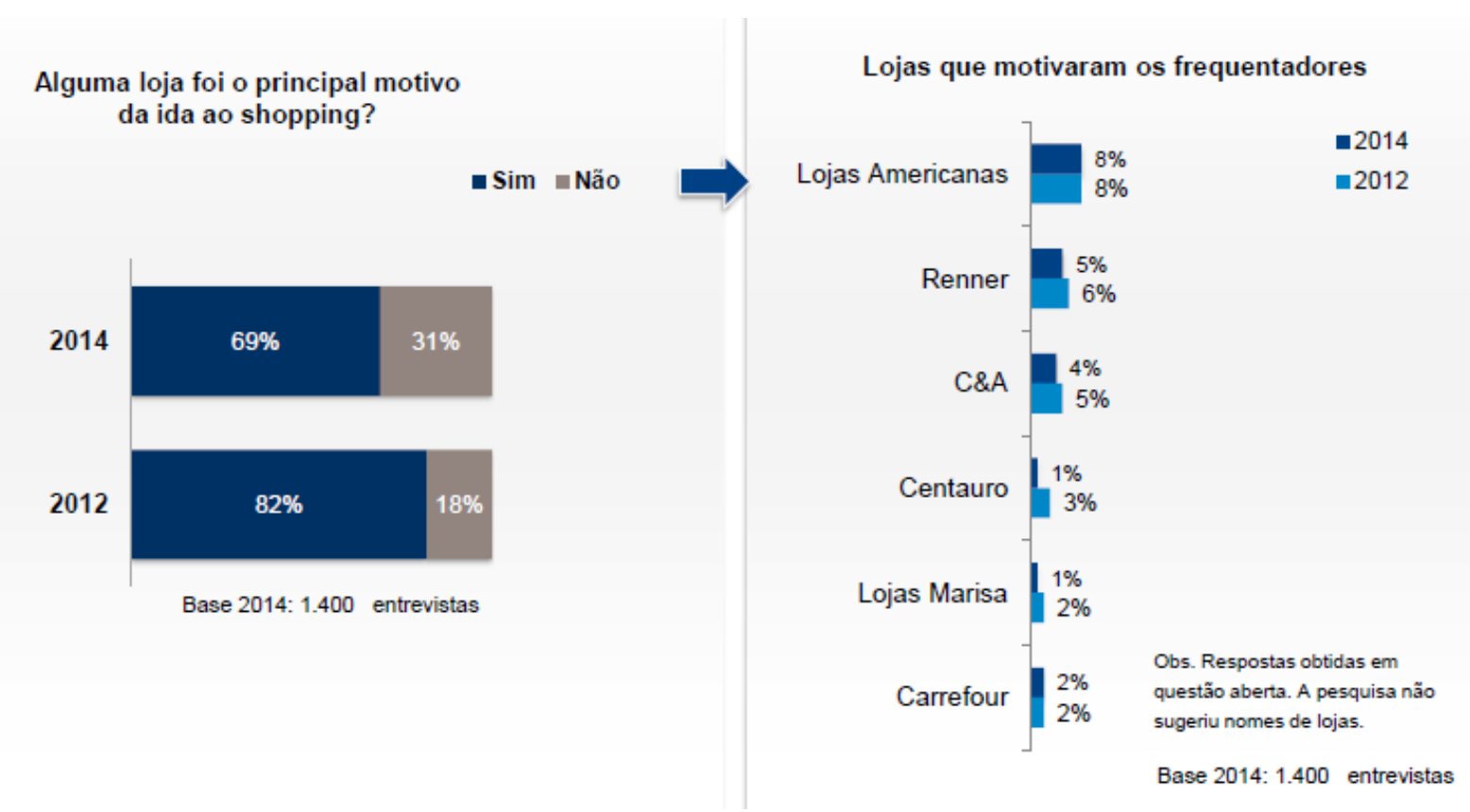

Fonte: Abrasce (2015). 
Ainda de acordo com a ABRASCE, grupos de investidores nacionais e internacionais, que procuram oportunidades atrativas para empregar seu capital, estão se voltando para a indústria de shopping centers no Brasil, o que amplia ainda mais as possibilidades de negócios rentáveis futuros neste setor. Os números são expressivos conforme podemos observar nos gráficos 2 e 3 em relação à área bruta locável (ABL) e ao faturamento, respectivamente.

Gráfico 1- Evolução da ABL em shopping centers no Brasil (em milhões m²)

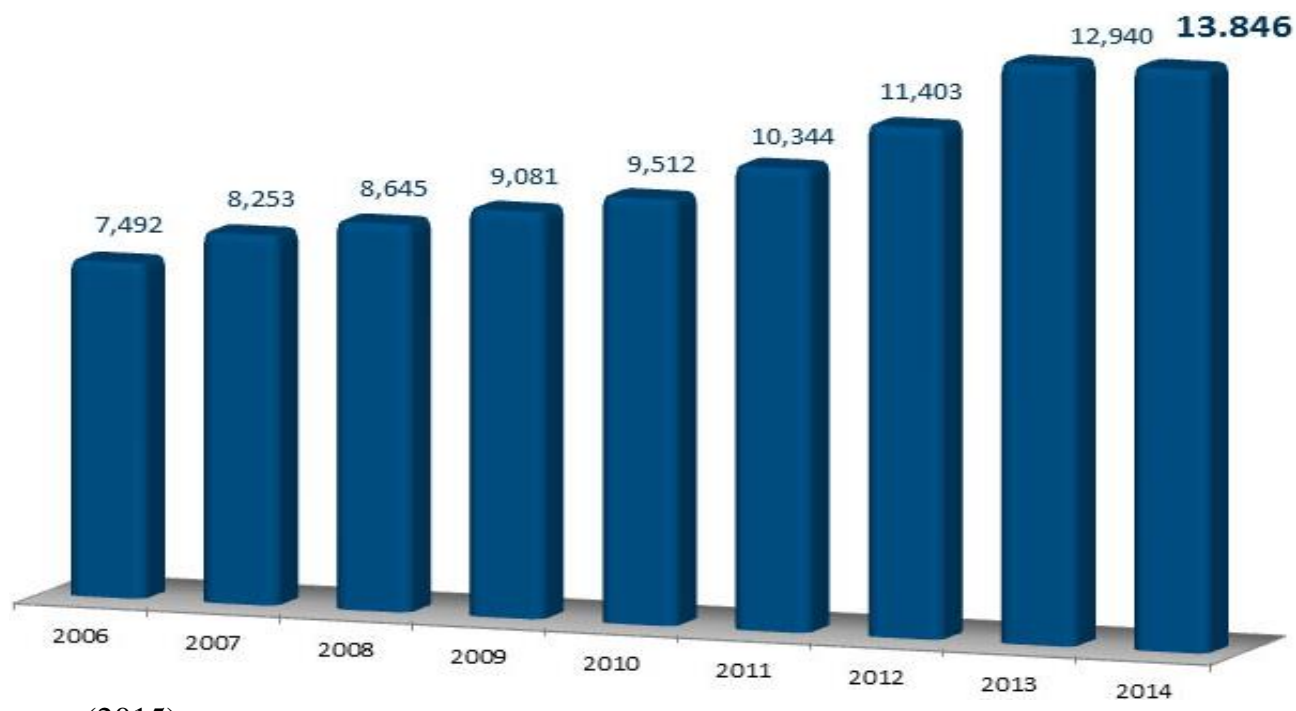

Fonte: Abrasce (2015)

Gráfico 2-Evolução do faturamento em shopping centers no Brasil (em bilhões de R\$)

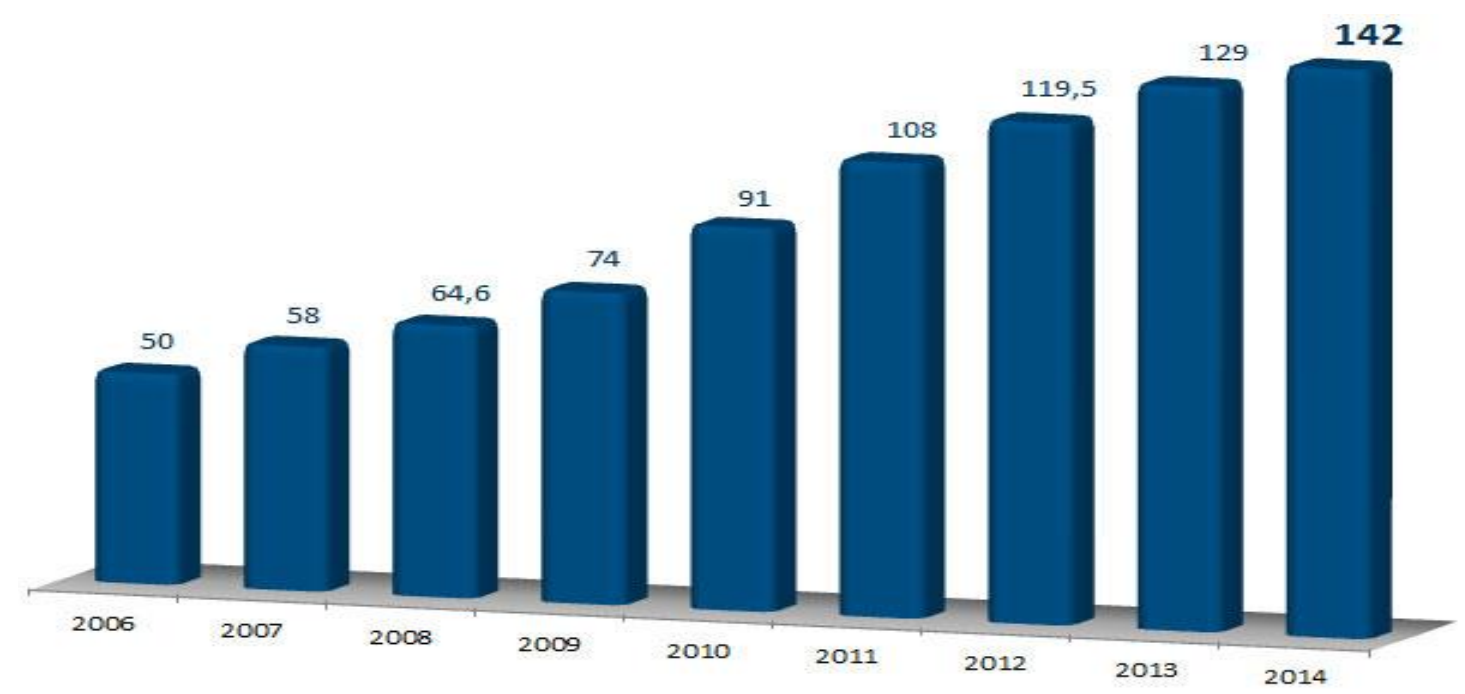

Fonte: Abrasce (2015) 
Mesmo com este crescimento, no entanto, as lojas dentro dos shoppings estão passando por uma competição que se acentua, não somente com outras lojas, situadas em shoppings ou não, mas também com outras modalidades de varejo, como as vendas diretas (em que demonstradores são responsáveis pela venda do bem/serviço); o marketing direto (por meio do telemarketing e compras eletrônicas); a venda automática (por meio das máquinas de venda), e os serviços de compras (um modelo de varejo sem loja que atende a grupos específicos de clientes como conselhos de classe, por exemplo (KOTLER; KELLER, 2006). As figuras 3 e 4 revelam como o comércio eletrônico tem atraído, cada vez mais, os clientes de lojas de shoppings em geral. Esta perspectiva exige, por parte dos gestores de lojas, ações de marketing que possam, não só cotejar os clientes potenciais, mas, sobretudo, fidelizá-los, adquirindo, assim, vantagem competitiva frente aos seus rivais.

Figura 3: compras pela internet

\section{$39 \%$ compraram pela internet} nos últimos 12 meses

Base 2014: 3.749 entrevistas

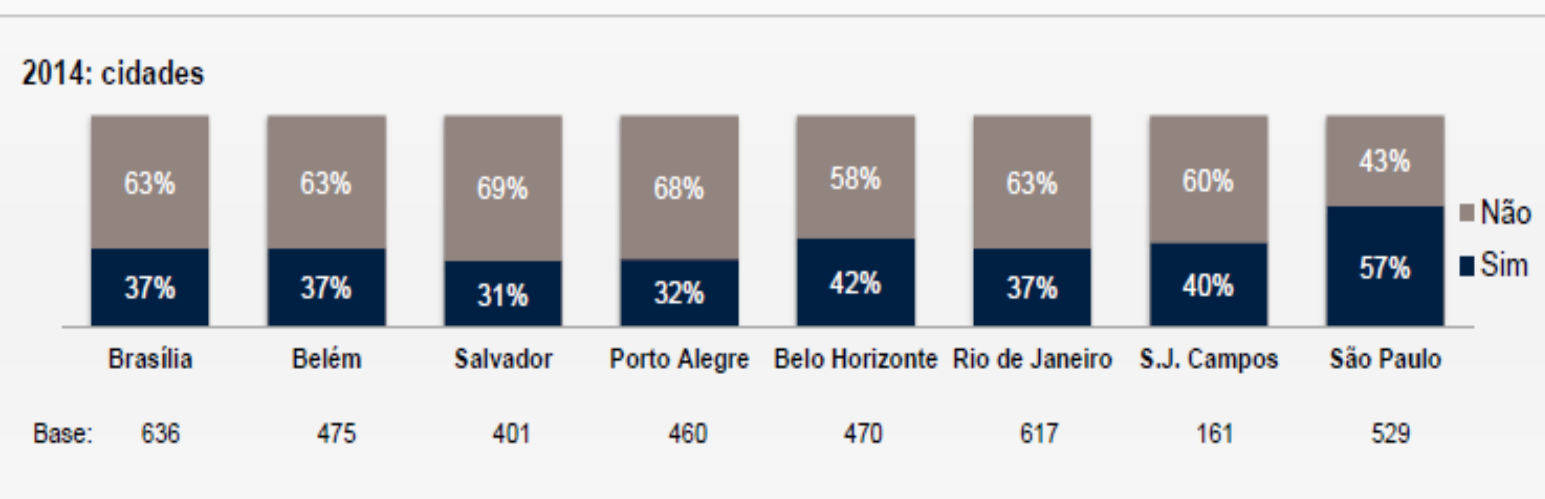

2014: Demográficos

\begin{tabular}{|l|c|c|}
\hline \multirow{2}{*}{$*$} & \multicolumn{2}{|c|}{ Gênero } \\
\hline & Masc & Fem \\
\hline Base & 1.634 & 2.115 \\
\hline Comprou nos últimos 12 meses & $43 \%$ & $36 \%$ \\
\hline
\end{tabular}

\begin{tabular}{|c|c|c|}
\hline \multicolumn{3}{|c|}{ Classe Social } \\
\hline A & B & CD \\
\hline 617 & 2.003 & 1.124 \\
\hline $55 \%$ & $44 \%$ & $22 \%$ \\
\hline
\end{tabular}

\begin{tabular}{|c|c|c|c|}
\hline \multicolumn{4}{|c|}{ Faixa Etária } \\
\hline 16 a 19 & 20 a 29 & 30 a 44 & 45 \\
ou mais \\
\hline 562 & 1.356 & 1.102 & 729 \\
\hline $36 \%$ & $44 \%$ & $40 \%$ & $33 \%$ \\
\hline
\end{tabular}

Fonte: Abrasce (2015). 
Figura 4: Compras pela internet

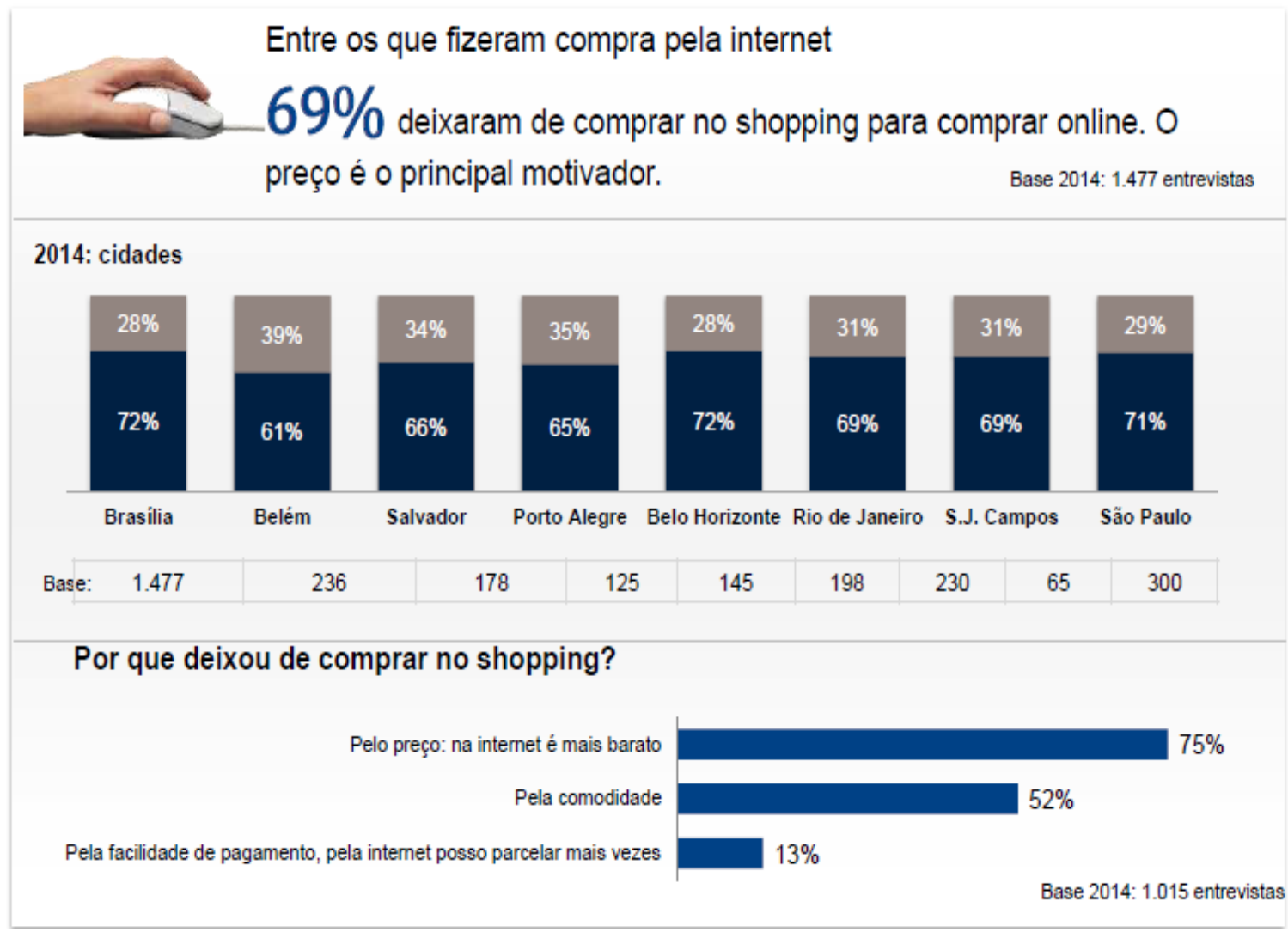

Fonte: ABRASCE (2015).

\subsection{Problema de pesquisa}

A literatura sobre a fidelidade no varejo de shoppings tem se focado na questão da fidelidade do consumidor ao shopping em si ou às lojas que ele abriga, ou ainda de sua lealdade ao shopping como antecedente da sua lealdade à loja dentro dos shoppings (MAJUMDAR, 2005). No entanto, pouco tem se analisado sobre o impacto da lealdade à loja como antecedente da lealdade aos shoppings. Neste sentido, os estudos de Rabbanee et al (2012) contribuíram, primariamente, para preencher esta lacuna ao afirmarem que os consumidores tendem a ser fiéis a uma loja em função do valor monetário percebido.

Em um estudo sobre os antecedentes da lealdade do consumidor aos bancos varejistas, Lewis e Soureli (2006) também encontraram que o valor monetário percebido pelos clientes exerceu algum tipo de influência sobre sua lealdade a determinado banco. No entanto, até onde se sabe, estes trabalhos revelaram uma preocupação, exclusivamente, com o valor percebido monetário, deixando de lado outros aspectos de valor associados, por exemplo, aos benefícios 
não monetários (conveniência, comodidade, economia de tempo, redução do estresse psicológico etc.). Ou seja, não foram examinadas as relações das variáveis como o prestígio da loja, sua imagem, seu ambiente, além de sua localização, como antecedentes do valor percebido pelos clientes. Com base nesta realidade, este trabalho propõe-se a responder à seguinte questão de pesquisa: $O$ valor percebido pelo cliente, na perspectiva dos benefícios, é um fator relevante para sua fidelização a uma loja situada dentro de um shopping?

\subsection{Objetivos da pesquisa}

O objetivo principal deste estudo é verificar se o valor percebido pelo cliente é importante para produzir sua lealdade à determinada loja localizada dentro de shopping centers. $\mathrm{O}$ valor percebido de loja, a partir da ótica dos benefícios, é a avaliação que os clientes fazem sobre os benefícios advindos de sua experiência de compra com a loja, com base em seus sacrifícios prévios (monetário e não monetário) para comprar lá.

E como objetivos específicos:

1. Analisar se o ambiente da loja localizada em shopping (no que se refere à música ambiente e à luz interna da loja, layout, à disponibilidade de mercadoria na loja, e ao desempenho dos vendedores) é percebido como um benefício pelos clientes, sendo fonte geradora de valor.

2. Verificar se a imagem corporativa da loja situada em um shopping é percebida como um benefício pelos clientes, sendo fonte geradora de valor.

3. Descobrir se o prestígio da loja situada em um shopping center é percebido como um benefício pelos clientes, sendo fonte geradora de valor. 
4. Descobrir se o local onde a loja está situada, no interior do shopping, é center é percebido como um benefício pelos clientes, sendo fonte geradora de valor.

\subsection{Justificativa para a realização do estudo}

Com uma grande importância para o estudo do comportamento do consumidor, o valor percebido tem recebido relativa atenção na literatura de marketing. Porém, muito em função da dificuldade na operacionalização de seus construtos, as abordagens empíricas sobre o tema são relativamente recentes. Como os estudos empíricos requerem definições operacionais, no caso do valor percebido, estas foram prejudicadas em função tanto do amplo espectro de outros construtos envolvido na formação do julgamento de valor quanto dos efeitos comuns resultantes de factores psicológicos individuais (AL-SABBAHY, 2004).

Os estudos sobre o valor percebido, de abordagem unidimensional, têm-se centrado no tradeoff entre os benefícios e os sacrifícios impostos aos clientes quando estes resolvem comprar algum bem/serviço. A grande maioria das pesquisas utiliza em suas abordagens comumente, embora não exclusivamente, os aspectos monetários destes sacrifícios, não capturando adequadamente as dimensões deste construto (CHEBAT et al, 2009; RABBANEE et al, 2012). Os benefícios não monetários como status, economia de tempo, facilidade de acesso etc. compõem um amplo espectro do valor percebido que não podem ser negligenciados (SÁNCHEZ-FERNÁNDEZ; INIESTA-BONILLO, 2007).

A abordagem multidimensional do valor percebido, ao considerar além dos aspectos racionais, os afetivos, ecoa os novos desenvolvimentos teóricos na área do comportamento do consumidor, ao se referir ao papel desempenhado pelos sentimentos nos hábitos de compra e consumo. Uma vez que o valor percebido é uma variável dinâmica que também é experienciada após o consumo, é necessário incluir reações subjetivas ou emocionais que são gerados no consumidor (MOLINER et al, 2007).

Portanto, a principal motivação para este estudo foi verificar a fidelização do consumidor à determinada loja a partir de sua percepção de valor percebido de loja, na perspectiva dos 
benefícios, ou seja, aquele derivado dos benefícios não apenas monetários, como economia de tempo (advinda com menos tempo para se pesquisar bens/serviços disponíveis nas lojas, conveniência (acessibilidade à loja em função de sua boa localização, qualidade de atendimento (bom relacionamento interpessoal com vendedores, tratamento personalizado por parte dos vendedores da loja), benefício psicológico (confiabilidade decorrente do prestígio da loja com tradição de mercado), comodidade (ambiente da loja aprazível para a experiência de compra do cliente (CALLARISA et al, 2011).

A localização de lojas dentro do shopping center é um tema discutido na literatura do marketing de varejo sob a perspectiva do proprietário de lojas ou do administrador do shopping. Pelo lado do proprietário de loja, a localização é vista como um instrumento de vantagem competitiva pelo poder que determinado local possui de atrair clientes para a loja. Do ponto de vista do administrador do shopping, este busca maximizar a cobrança dos valores de aluguel e da taxa de ocupação - esta última formada pelos fundos de promoção (valor para divulgação e publicidade do empreendimento) e condomínio (CRAIG et al, 1984; R. KUO et $a l$, 2002; TURHAN et al (2013). No entanto, até onde se sabe, não se tem analisado a possível influência que o local onde a loja está situada dentro do shopping exerça sobre os clientes. Esta é uma preocupação que também nos motivou na realização deste trabalho.

Outra questão relevante para este estudo diz respeito à possível influência que o prestígio, derivado da longa existência da loja no mercado, possa exercer em sua decisão compra. Não se tem conhecimento de trabalhos na área de marketing de varejo que tenham contemplado esta questão. 


\subsection{Shopping centers}

Várias definições estão presentes na literatura sobre shopping centers: conforme Dawson e Lord (2012), estão relacionados a um grupo de estabelecimentos comerciais concebido, desenvolvido, comercializado, gerenciado e legalmente estabelecido como uma unidade. Formados, geralmente, por um conjunto de lojas, administrados de forma centralizada, com uma área de estacionamento grande e convenientemente disponível (TUN-HSIANG YU et al, 2012). Nicholls et al (2002) afirmam que são estabelecimentos compostos de uma ampla gama de mix de lojas, com a presença de uma ou mais lojas âncoras, comumente as de departamento, que anunciam maciçamente e que tem como finalidade estimular o tráfego em seu interior. A essência do shopping center reside no conceito de um ambiente de varejo administrado e controlado. Tanto a sua organização interna, quanto a sua operação, é gerenciada pelo proprietário. Assim, o mix de lojas, a promoção, a segurança, a manutenção etc. são administrados e controlados, visando à maximização do poder do shopping como um todo. (DAWSON; LORD, 2012)

A visão funcional do shopping refere-se a sua capacidade de satisfazer as transações econômicas ao acomodar as conexões entre lojistas e clientes. Sua outra função diz respeito a criar um local interessante que traga uma impressão única e icônica a quem o visita através de sua arquitetura e design interior (KUSUMOWIDAGDO et al, 2015). Na mesma vertente, Kamarulzaman e Lih (2010), e Karim et al (2013), apregoam que, independentemente de seu tamanho, todos os shoppings são áreas onde as pessoas podem se socializar, desfrutar de atividades de lazer e comprar os produtos de que necessitam. Os shopping centers converteram-se não somente em locais potenciais para o hábito de comprar, mas em um ambiente repleto de marketing de experiências em si mesmo, conforme salientado por Patel e Sharma (2009). Os shoppings buscam atrair os consumidores, apelando para a conveniência de dispor de uma ampla variedade de lojas e mercadorias localizadas em um único local (one-stop). Ao longo do tempo, os shoppings têm crescido e sua conveniência de one-stop tem se ampliado para as áreas de serviço e entretenimento (praça de alimentação, 
exposição de artes, restaurantes, cinemas, teatros, clicas médicas e odontológicas etc.) (BLOCH et al,1994).

Embora os shoppings estejam sofrendo uma concorrência intensa, não apenas de outros modelos varejistas, mas também do comércio eletrônico, e já não exerçam mais um domínio absoluto no varejo, Nicholls et al (2002) atestam que eles ainda continuam a usufruir de uma certa vantagem competitiva em função de suas características mais distintivas como a incorporação do entretenimento, a seleção de mercadorias, a presença de lojas de departamento e de especialidades.

Os administradores de shoppings enfrentam desafios frente ao ambiente competitivo presente. Neste contexto, terão de se tornar mais orientados para o consumidor no sentido de que mais atenção terá de lhe ser assegurada no que tange às razões do "por que, quando, o quê, quem, onde, e como" o consumidor compra no shopping center. Como o ambiente de shopping center difere em características econômicas, sociais e psicológicas importantes, ele é capaz de exercer uma certa influência sobre o comportamento individual e coletivo do consumidor. $\mathrm{O}$ sucesso e o impacto invejáveis dos shoppings guardam relação com a capacidade que ele tem de melhorar a vida em comunidade (FEINBERG; MEOLI, 1991).

\section{$2.2 \quad$ Lealdade à loja.}

De acordo com Bloemer e Ruyter (1998), Neal (1999), Majumdar (2005), Swimberghe et al. (2009), Tripathi (2009) e Zhang et al (2011), a lealdade à loja pode ser concebida como uma ação comportamental intencional por parte do consumidor de revisitar e comprar em uma certa loja ao longo do tempo. Além disso, González-Benito e Martos-Partal (2012) empregam uma perspectiva comportamental e mensuram a fidelidade à loja como sendo o grau de concentração do orçamento de compras do cliente com determinado varejista. Ray e Chiagouris (2009) acrescentam a ideia de comprometimento com a loja como componente essencial da lealdade à loja. Bloemer e Ruyter (1998) afirmam que o comprometimento com a loja, que vem a ser o vínculo duradouro do indivíduo a uma loja tanto em seu processo de escolha quanto na sua recomendação aos outros, é condição sine qua non, para que ocorra a lealdade. 
Yang e Peterson (2004) expressam a fidelidade do cliente, pela intenção comportamental dos clientes de contínua ou incessantemente, realizar negócios com sua loja atual, e recomendá-la a outras pessoas. Omar et al (2010) afirmam que a lealdade à loja pode ser compreendida como atitudes altamente positivas, por parte do consumidor, em relação a certa loja e uma intenção comportamental de comprar nesta loja, o que acaba produzindo repetitivas compras na mesma loja, independentemente das influências situacionais ou das ações de marketing desenvolvidas pelos competidores para modificar o comportamento de compra deste consumidor.

Fullerton (2003) assinala que a lealdade à loja tem dois matizes, afetivo e de continuidade. No primeiro caso, o indivíduo tem um sentimento de pertencimento e, no segundo, ele acredita que incorrerá em perdas caso se desvincule deste relacionamento. A lealdade à loja, de acordo com Rabbanee et al (2012), e Tripathi (2009) traz uma série de benefícios tais como a propaganda boca a boca e a retenção dos clientes, o que se converte em redução das despesas de marketing. Ainda para este último, os clientes leais devem ser vistos como fatores-chave para a sobrevivência e o sucesso de muitas empresas, pois uma leve queda no número de clientes fiéis pode fazer com que tanto os lucros quanto o valor global da empresa decaiam. A lealdade do cliente à loja gera um relacionamento estável e de longo prazo, mutuamente lucrativo (RAVALD; GRÖNROOS, 1996).

Knox e Denison (2000) afirmam que, embora, as expressões lealdade à loja e retenção de clientes sejam frequentemente usadas como substitutas para os padrões de comportamento de compra, elas, raramente, são medidas e utilizadas de maneira precisa. Segundo eles, uma vez que os consumidores são muito improváveis de demonstrar lealdade exclusiva a um grupo de lojas, a fidelidade à loja é relativa na prática, daí a dificuldade de sua mensuração com exatidão. A repetição de visitas à loja acaba sendo, por muitos analistas, a medida conveniente da mensuração da fidelidade. A crítica que os autores colocam sobre esta forma de mensuração tem a ver com a ausência do volume gasto, pois, ainda de acordo com os mesmos, alguém pode visitar, várias vezes, certa loja e apresentar um volume de gastos inferior a quem, por exemplo, poderia ir à loja uma única vez.

Majumdar (2005) identificou três medidas para o construto de intenções da lealdade à loja: probabilidade de continuar comprando no futuro, probabilidade de comprar outras categorias de mercadorias no futuro, e a disposição de recomendar a loja a amigos e pessoas próximas. 
Em seu estudo, ele examina o impacto da impressão geral da loja, percepções de valor (preço versus qualidade e vice-versa) e as promoções na loja sobre a intenção do consumidor de se tornar leal à loja. De acordo com Neal (1999), a lealdade do consumidor a certa loja deve-se em função de sua experiência de valor nas suas trocas comerciais com a mesma. Existe um equívoco, para ele, de tentar utilizar a satisfação, que é uma atitude, para prever a lealdade do consumidor, que é um comportamento. Ainda para o autor, o valor prevê escolhas e, portanto, lealdade.

\subsection{Valor percebido de loja pelo cliente na perspectiva dos benefícios.}

A teoria do valor percebido gira em torno de duas vertentes: a primeira, de cunho unidimensional, apregoa que o valor é derivado de duas partes, quais sejam, os benefícios recebidos (econômico, social e de relacionamentos) e os sacrifícios impostos, quer sejam de ordem monetária ou não (o tempo dispendido na aquisição do produto/serviço, o esforço da busca por este produto/serviço, o risco pela utilização do produto/serviço e a conveniência deste uso) (VERMA, 2012; MOLINER et al, 2007). Esta perspectiva contempla o fato de que este construto unidimensional pode ser derivado dos efeitos de múltiplos antecedentes, mas não permite a visão de que o valor é um conceito agregado formado a partir de vários componentes (SÁNCHEZ et al, 2006).

Por outro lado, Molliner et al (2007), revelam que uma abordagem multidimensional do valor percebido tem ganhado força, superando o problema da concentração da primeira abordagem em torno da teoria da utilidade econômica, ampliando seus limites para a visão experimental, ou seja, revelando que além do aspecto cognitivo, o valor percebido é eivado de componentes afetivos. Ainda de acordo com estes autores, também urge frisar que na equação do valor percebido, na relação entre benefícios e os sacrifícios incorridos, as variáveis afetivas devem estar presentes, uma vez que os benefícios emocionais podem afetar as escolhas do consumidor em relação aos competidores que se equivalem em outros atributos. Porque o valor percebido é um construto dinâmico que se estende até o pós-consumo, existe a necessidade de inclusão das reações emocionais (medo, raiva, inveja etc.) geradas no consumidor. 
Snoj et al (2004) também defendem que o valor percebido pelo consumidor é um conceito multidimensional, que está relacionado à sua expertise ou conhecimento sobre a compra e o uso de um produto. Sweeney e Soutar (2001), ao definirem o construto valor percebido, inseriram outras dimensões, além do preço e da qualidade, com o objetivo de desenvolver uma escala que fosse, ao mesmo tempo, útil, parcimoniosa e prática, e de fácil aplicação em várias situações de compra. Seus estudos comprovaram que múltiplas dimensões de valor explicam melhor as escolhas do consumidor, tanto estatística quanto qualitativamente, do que simplesmente o valor monetário, tais como o emocional (fruição ou prazer com o produto), ou o social (o que o uso do produto transmite aos outros). Por exemplo, o estudo mostrou que o valor emocional exerceu uma influência relevante na disposição dos consumidores quando da aquisição de bens duráveis, normalmente associados à orientação funcional.

Ravald e Grönroos (1996) vêm afirmando, há tempos, que ao fornecer valor superior para seus consumidores, as empresas conseguirão obter uma das mais importantes estratégias competitivas de sucesso, pois conseguirão se diferenciar da concorrência e, deste modo, assegurar uma vantagem competitiva sustentável. Na mesma linha, Erragcha e Gharbi (2012) afirmam que ao produzir valor para os clientes, gerando-lhes benefícios, as empresas conseguem estabelecer um relacionamento constante e sustentável com os mesmos, diferenciando-se, assim, de seus concorrentes e, obtendo, por conseguinte, vantagem competitiva sustentável frente aos seus rivais, pois como demonstrado por Yyun Yu (2014), Gallarza e Saura (2006), McDougall e Levesque (2000), o valor percebido exerce um efeito direto tanto na satisfação quanto na intenção de recompra do consumidor.

O valor percebido pelo consumidor deriva em larga escala, segundo Sirdeshmukh et al (2002), de sua confiança no relacionamento com a empresa fornecedora, a qual busca sempre ser competente operacionalmente, benevolente com seus clientes e disposta a resolver seus problemas. Ainda segundo os autores, a confiança também reduz as incertezas desta relação comercial entre ambos, ajudando os consumidores a criarem expectativas confiáveis com relação à empresa na busca de uma parceria contínua. 
Zeithaml (1988), Wang et al (2004), e Y. Kuo et al (2009) assinalam que o valor percebido pelo consumidor pode ser aferido a partir de quatro perspectivas: monetária, da qualidade, do benefício, e da psicologia social.

1. Sob a ótica do preço, o valor percebido é gerado quando menos montante de dinheiro é dispendido na aquisição de bens/serviços, tal como ocorre quando o consumidor lança mão de cupons de desconto ou promoções. Esta perspectiva está centrada na teoria econômica do excedente do consumidor, ou seja, o valor percebido é a diferença entre o maior preço que os consumidores estão dispostos a pagarem por um bem/serviço e o preço efetivamente pago.

2. $\quad \mathrm{Na}$ visão da qualidade, o valor percebido deriva da diferença entre o montante pago pelos bens/serviços e a qualidade percebida dos mesmos. De acordo com esta perspectiva, quanto menos se paga por um produto de alta qualidade, um valor percebido positivo será criado. De acordo com Zeithaml (1988), a qualidade percebida pelo consumidor refere-se ao seu julgamento sobre a excelência ou superioridade global de um produto quando o compara aos seus concorrentes em termos de atributos.

3. Na perspectiva dos benefícios, o valor é decorrente da avaliação global do cliente sobre a utility dos benefícios percebidos e dos esforços percebidos associados à aquisição dos bens/serviços. Os consumidores podem integrar suas percepções, de forma cognitiva, sobre o que eles recebem e o que têm de dar em troca quando da obtenção de bens/serviços. Contudo, tais esforços significam mais do que o dinheiro pago pelos produtos. Devem ser incluídos também os custos de ordem não monetária como, por exemplo: os de transação, os de pesquisa, os de negociação, os do tempo incorrido durante a compra. 
4. Por último, de acordo com a perspectiva da psicologia social, a criação de valor percebido pelo cliente reside no significado de comprar bens/serviços para demonstração junto ao seu núcleo social. Ou seja, os bens/serviços eivados de significados particulares (status econômico social e cultural social) são capazes de aumentar o autoconceito social.

O valor de loja percebido, na perspectiva dos benefícios, decorre da avaliação, por parte do cliente, entre os benefícios obtidos na sua compra e os esforços prévios (monetários e não monetários) que ele tem para comprar lá. O valor de loja percebido pelo cliente, sob esta ótica, portanto, é o foco deste estudo.

\subsection{Ambiente de loja}

Para Ry et al (2002) o ambiente de loja refere-se, basicamente, a três fatores: a) ambientaisluz, aroma, música; b) fatores de design- layout e disponibilidade de mercadoria, e c) fatores sociais- como, por exemplo, o desempenho dos vendedores para propiciar um ambiente de compras prazeroso. O layout refere-se à forma como os produtos estão expostos, como os corredores estão projetados etc. O sortimento, por usa vez, diz respeito ao conjunto total de itens ofertados pelo varejista. Seguindo a mesma linha de raciocínio de Baker et al (2002), Bharadhwaj e Sharma (2013), este trabalho é amplo na conceituação de ambiente de loja, contemplando os aspectos ambientais (iluminação, música, cor e aroma), os de design (disponibilidade e diversidade de mercadorias na loja), e os sociais (marketing experiencial na loja e a eficiência dos vendedores).

O ambiente de loja tem uma importância significativa no comportamento de compra, uma vez que ele pode atrair consumidores potenciais para visitar a loja, fazê-los gastar mais tempo dentro dela e incentivá-los a comprar mais mercadorias. No longo-prazo, o ambiente de loja pode atrair a lealdade do consumidor, na medida em que provê experiências de compra que estimulam a sua frequência de visitas e aumenta a imagem da marca. Um ambiente excitante deveria ser imprescindível para que os consumidores almejassem voltar à loja, como o caso de uma decoração interna atraente. Os clientes são mais estimulados pelos apelos visuais, 
conforto, recreação e estética dos cenários. Os estímulos visuais (arquitetura, cor, estilo, forma etc.) e funcionais (decoração, conforto, sinalização) são os vetores mais importantes no ambiente de serviços capazes de produzir impressões positivas no cliente e de atraí-lo (LEVY; WEITZ, 2012).

O ambiente de loja pode ser compreendido a partir de diferentes níveis de agregação: no nível elementar, pode se examinar os elementos ambientais individuais tais como a música, o ruído, a cor, o odor e a decoração, por exemplo. Em um nível mais agregado- o nível de fator - pode se estudar estes elementos como grupos (fatores), como, por exemplo, o ambiente, o design e os fatores sociais. O fator ambiental refere-se às características de fundo como temperatura, iluminação, ruído, música e odor do ambiente. O fator de design engloba estímulos presentes na vanguarda da consciência dos clientes, tais como a arquitetura, materiais, mercadorias etc. Os fatores sociais dizem respeito às condições sociais representadas pelo número, tipo e comportamento de clientes e funcionários da loja. Ao nível de fator de análise, busca-se manipular vários elementos pertencentes ao mesmo fator para se projetar uma imagem particular de loja. Isto também pode ser conduzido no nível agregado. Seu principal objetivo é analisar o relacionamento entre as emoções induzidas por um ambiente particular e os comportamentos neste ambiente, em vez de procurar saber como as emoções ou comportamentos estão relacionados às características do ambiente. O ambiente de loja pode afetar o comportamento dos clientes de várias formas, como se pode notar na figura 5 abaixo (LAM, 2001). 
Figura 5- Um quadro integrativo dos efeitos do ambiente de loja

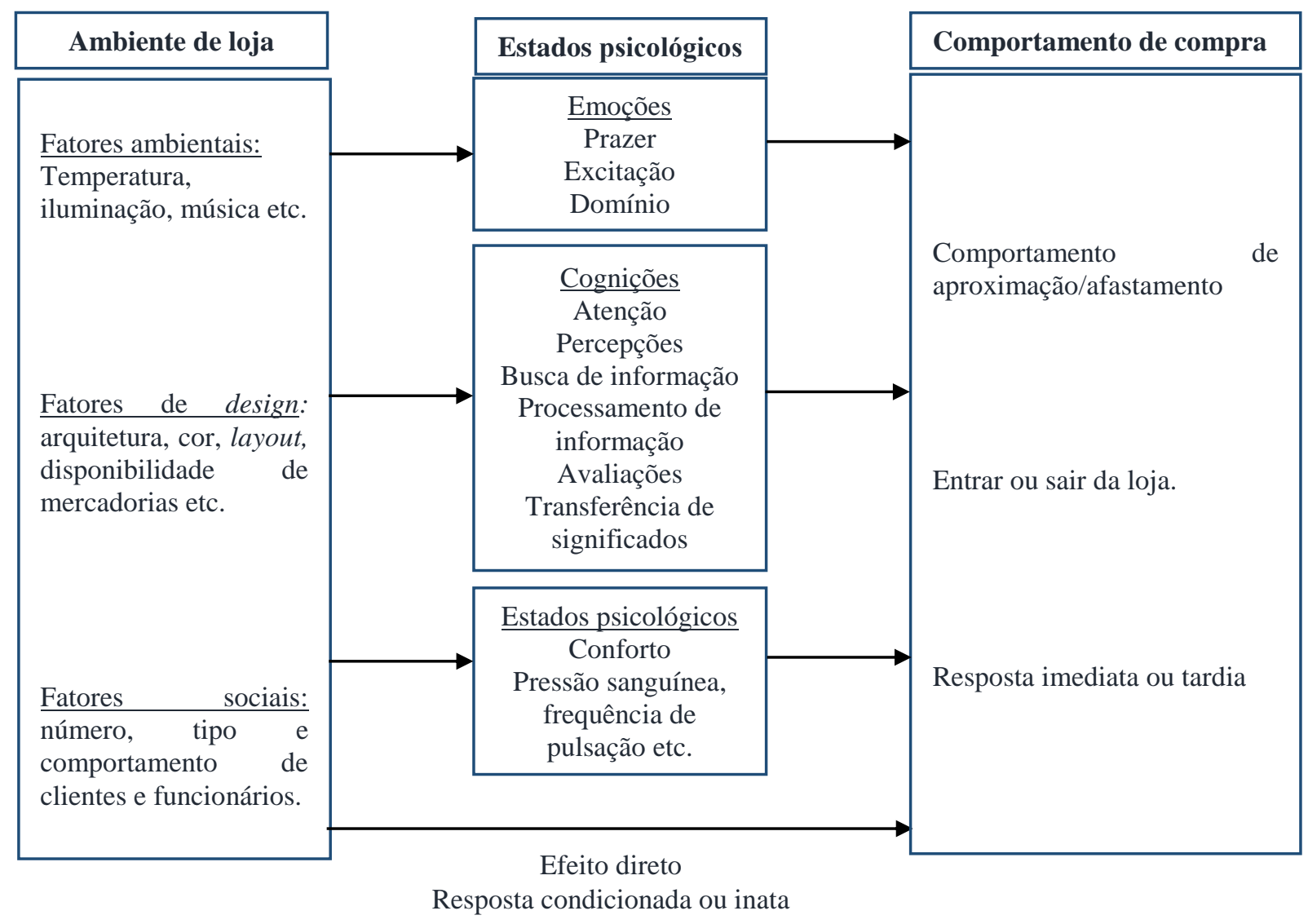

Fonte: Lam (2001, p. 191, tradução e adaptação nossa).

\subsubsection{Fatores ambientais:}

\subsubsection{Música e iluminação.}

A atmosfera da loja é construída, no que se refere ao seu aspecto ambiental, de características relacionadas, por exemplo, à iluminação, aroma e música. (MOHAN et al, 2013). A atmosfera da loja em um shopping é eivada de significação holística, no sentido de que os consumidores, cada vez mais, baseiam suas experiências de compra em apelos emocionais em detrimento do aspecto funcional da compra. Assim, torna-se essencial que as lojas presentes em shoppings possam criar ambientes aprazíveis que permitam seus clientes vincular estes ambientes a experiências de compras positivas que o tornarão, no futuro, um consumidor fiel.

Singh e Prashar (2013) confirmam que os fatores ambientais das lojas em um shopping associados à iluminação, aroma interno, música e cor exercem um poder de atração dos 
consumidores potenciais, como também já notado por Areni e Kim (1994) ao afirmarem que os restaurantes tipicamente empregam iluminação suave a fim de criar um ambiente romântico, mesmo podendo comprometer sua funcionalidade para os clientes, ao lhes dificultar a leitura do cardápio, demonstrando com isso, que o ambiente se fez mais importante que a função. Mohan et al (2013) mostraram que o ambiente de loja associado aos fatores ambientais tem uma forte influência nas compras por impulso.

Em uma pesquisa sobre lojas revendedoras de vinho, de Areni e Kim (1994), ficou evidenciado que uma iluminação mais intensa exerceu um papel relevante ao influenciar os clientes a examinarem e a manusearem as mercadorias expostas naquelas áreas em relação a outras menos iluminadas. Este efeito se mostrou mais acentuado para as garrafas de vinho que se encontravam em prateleiras ao nível dos olhos. Tais resultados também foram analogamente verificados nos estudos de Summers e Hebert (2001) sobre lojas de cintos, demonstrando o impacto da iluminação na disposição dos clientes em experimentarem mais itens.

Outro fator ambiental imprescindível para as lojas estimularem seus clientes pôde ser visto nas pesquisas de Morrin e Chebat (2005), em que se observou que os clientes mais envolvidos com a decisão de compra, ou seja, os que buscam mais informação e comparam mais os bens/serviços, tenderam a valorizar muito especialmente aqueles ambientes com aroma agradável e característico, obviamente pela necessidade de permanecer mais tempo na loja.

\subsubsection{Fatores de design:}

\subsubsection{Layout}

Para Van Rompay et al (2012), o layout de loja refere-se ao posicionamento de elementos físicos tais como prateleiras e displays de produtos em todo o ambiente de loja. De maneira mais abrangente, Mohan et al (2012), afirmam que o layout diz respeito à forma como os produtos, carrinhos de compras, e corredores são organizados, o tamanho e a forma dos itens, e as relações espaciais entre eles. Também inclui a concepção do espaço e a alocação, o agrupamento e a colocação da mercadoria. 
Layouts bem desenhados são extremamente importantes em função de seu poder de impactar o ambiente de loja: por exemplo, as decisões relativas ao layout da loja podem minimizar a percepção de lotação dentro da loja, pelos clientes, por meio de um layout espaçoso, atenuanando efeitos negativos resultantes de muitos compradores que visitam a loja ao mesmo tempo (IJAZ ET AL, 2014.). Da mesma forma, um bom layout facilita enormemente uma boa pesquisa no interior da loja, permitindo aos clientes ver a disponibilidade de diferentes categorias de produtos e também o sortimento dentro de cada uma delas (MOHAN et al, 2012).

Baseados na literatura de varejo sobre layout, Vrechopoulos et al (2004), Ijaz et al (2014) afirmam que existem três grandes tipos de layout de loja, conforme demonstrado na figura 6 , a saber:

a) GRID: é um arranjo retangular de displays e corredores longos que geralmente correm paralelamente um ao outro, e levam os clientes até os caixas localizados em frente da loja, por onde os clientes entram e saem. Tem sido demonstrado que este tipo de layout facilita o comportamento de compras rotineiro e planejado dos clientes, oferecendo-lhes flexibilidade e velocidade na identificação de produtos pré-selecionados que aparecem em sua lista de compras. É amplamente favorecido pelo setor de mercearia porque a maioria dos clientes que visitam estes departamentos já tem planejado suas compras.

b) FREEFORM: é um arranjo de fluxo livre e assimétrico de displays e corredores, empregando uma variedade de diferentes tamanhos, formas e estilos de exibição. Neste padrão, o cliente desfruta de grande liberdade para se locomover em qualquer direção dentro da loja. É usado principalmente por grandes lojas de departamento. Este tipo de layout foi concebido para aumentar o tempo que os consumidores estão dispostos a gastar na loja, pois facilita enormente a navegabilidade dentro dela. 
c) RACETRACK (Boutique): Neste tnpo de layout, a área de vendas está organizada em áreas individuais, semi-separadas, cada uma construída em torno de um tema de compras particular. Este tipo de layout leva o cliente ao longo de caminhos específicos para fazê-lo visitar muitas seções ou departamentos da loja quanto possível, porque o principal corredor facilita o movimento de clientes através da loja. O varejista que adota esta disposição cria uma experiência de compra incomum, interressante e divertida.

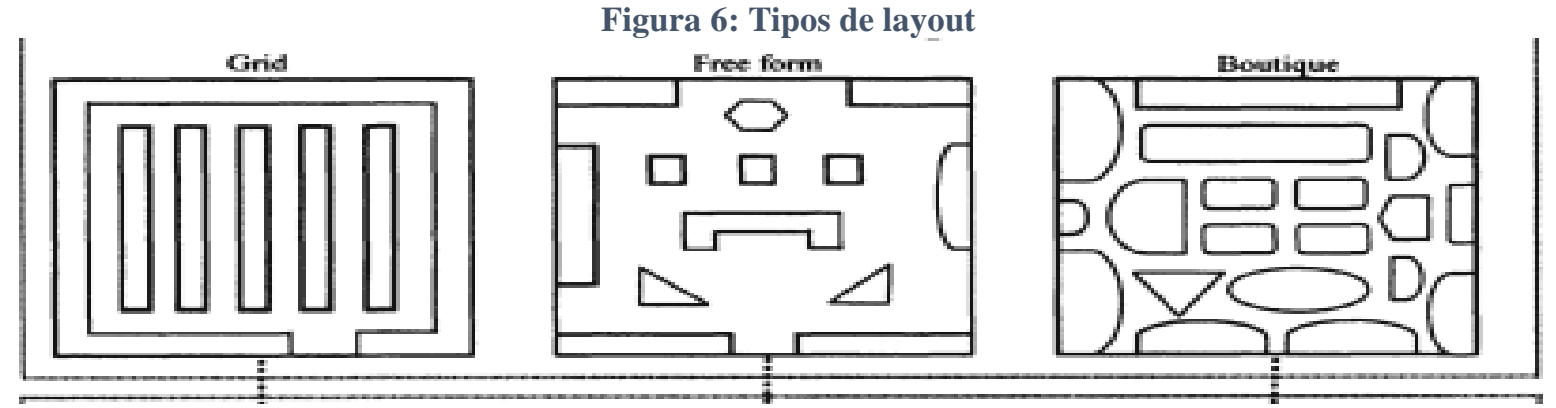

Fonte: Ijaz et al (2014, p. 313, tradução nossa).

\subsubsection{Disponibilidade de mercadoria na loja}

Segundo Levy e Weitz (2012), enquanto a variedade de mercadorias refere-se às categorias que são comercializadas por um varejista (amplitude da mercadoria), o sortimento diz respeito ao número de itens ofertados nesta categoria (profundidade da mercadoria). Porém, segundo os autores, o mais importante para um lojista, do que possuir alta amplitude e profundidade de mercadorias, é a disponibilização destas mercadorias para os seus clientes. Eles devem ter a certeza de que encontrarão facilmente, sempre que necessitem, os produtos comercializados na loja.

Westbrook (1981) afirma que todas as experiências incorridas por um cliente ao comprar em um varejista são amplamente diversas, uma vez que estes estabelecimentos são organizações complexas que envolvem produtos, pessoas, ambiente físico, políticas e procedimentos etc. com os quais os clientes tem frequentes contatos ao longo do tempo. Estas experiências foram por ele categorizadas em dois tipos: aquelas relacionadas a estar na própria loja e lidar com a organização, e as relacionadas a consumir os produtos e serviços adquiridos do varejista. A disponibilidade e a diversidade de mercadorias inserem-se no primeiro caso. 
Baker et al (2002) afirmam que a disponibilidade e a diversidade de mercadorias favorecem a conveniência do consumidor, minimizando sua percepção de custos psíquicos associados à sua experiência de compra (como os associados ao tempo de procura), favorecendo sua experiência e seu comportamento de compra. A maior incerteza que um consumidor se depara quando procura um produto é em relação a sua disponibilidade na loja. Quando as pessoas estão empenhadas em comprar um item fora de estoque, elas tendem a reagir negativamente a esta situação, ficando menos satisfeitas em seu processo de decisão e com uma maior probabilidade de trocar de loja. Quando o consumidor sabe que existe a disponibilidade de mercadorias na loja, ele considera seu tempo de deslocamento até a loja, possivelmente, como um investimento ao invés de um gasto inútil, minimizando, então, o impacto negativo do tempo de deslocamento. Por outro lado, se os consumidores não têm esta certeza quanto à disponibilidade das mercadorias na loja, eles encararão o tempo de deslocamento até a loja como gastos supérfluos potenciais.

Em seus estudos, Grewal et al (2012) buscaram comprovar que os clientes esperavam pagar menos quando havia a incerteza da disponibilidade da mercadoria na loja e seu tempo de deslocamento até a loja era grande. Por outro lado, se havia a certeza da disponibilidade da mercadoria na loja, o tempo de deslocamento não exercia nenhuma influência na disposição do cliente em pagar o preço cobrado pela loja. Ao proporem uma escala para medir a qualidade do serviço em lojas de varejo, Dabholkar et al (1996), descobriram que os clientes enxergavam a disponibilidade de mercadorias como um reflexo da confiabilidade de seus serviços, o que, por sua vez, contribuía, significativamente para o aumento do valor percebido por eles.

\subsubsection{Fatores sociais:}

\subsubsection{Nível do atendimento dos vendedores na loja.}

Desenvolver e manter uma política de harmonia com os consumidores facilita os relacionamentos e reduz atritos entre as lojas e seus clientes. Isto inclui solucionar os problemas e as reclamações dos clientes e ser proativo em relação aos mesmos, pois se um vendedor puder, constantemente, perceber, antecipar e reagir às demandas dos clientes em 
diferentes situações, estes ficarão satisfeitos com os serviços personalizados, confiarão no vendedor e, eventualmente, serão leais à loja no longo prazo. Saber apresentar os produtos de maneira eficiente e saber lidar com clientes reflete o papel desempenhado pelos vendedores como uma representação externa da loja, tendo em vista que eles também representam os programas de comunicação da loja e, assim, têm uma influência direta sobre como a imagem da loja e de suas marcas são anunciadas para os clientes. Para isto, é necessário que os vendedores saibam entender as necessidades dos clientes, busquem esclarecer suas dúvidas, façam demonstrações bem elaboradas etc. (BEHRMAN; PERREAULT JR, 1982; BATEMAN; VALENTINE, 2015; CHEN; JARAMILLO, 2014; GAMMOH et al, 2014).

Bateman e Valentine (2015) têm afirmado que a orientação dos vendedores para as necessidades dos clientes pode impactar a eficácia e os resultados das interações entre vendedores e clientes, pois quando os vendedores são mais atenciosos com as necessidades individuais dos clientes, ao invés de simplesmente fornecer informações sobre o produto/serviço, eles provavelmente geram uma obrigação recíproca dos clientes a responder da mesma forma, como resultado do cuidado responsável que foi demonstrado durante a interação de vendas.

O conceito de "vendedores orientados para o cliente em encontros de vendas" foi originalmente proposto por Saxe e Weitz (1982) que afirmavam que as vendas orientadas para os clientes podiam ser vistas como uma prática de marketing por parte do vendedor individual de maneira a atender as necessidades dos seus clientes. Ainda segundo os autores, vendedores altamente orientados para os clientes, engajam-se em comportamentos que visam ao aumento da satisfação dos clientes no longo prazo, e buscam evitar aqueles que possam resultar em insatisfação dos clientes. Homburg et al (2011) modernamente reformularam o conceito originalmente proposto pelos autores anteriores, ao afirmarem que este ocorre quando um vendedor identifica e satisfaz as necessidades e interesses do cliente em diferentes estágios do encontro de vendas. Segundo estes autores, esta definição exige uma maior especificação com relação aos diferentes estágios de um encontro de vendas. Cinco grandes estágios são então considerados por Jobber e Lancaster (2006) apud Homburg et al (2011): a) identificação de necessidades, b) apresentação, c) objeções, d) negociação e e) fechamento. Como representado na figura 3, a orientação para o cliente em encontros de vendas pode ser concebida como um construto a partir de cinco dimensões, cada uma correspondendo a um estágio específico no encontro. 
Figura 7: Dimensões da orientação para o cliente pelo vendedor em um encontro de vendas

Estágios de um encontro de vendas Jabber e Lancaster (2006, p. 250) apud Homburg et al (2011)
Dimensões da orientação para o cliente em encontros de venda
Definição

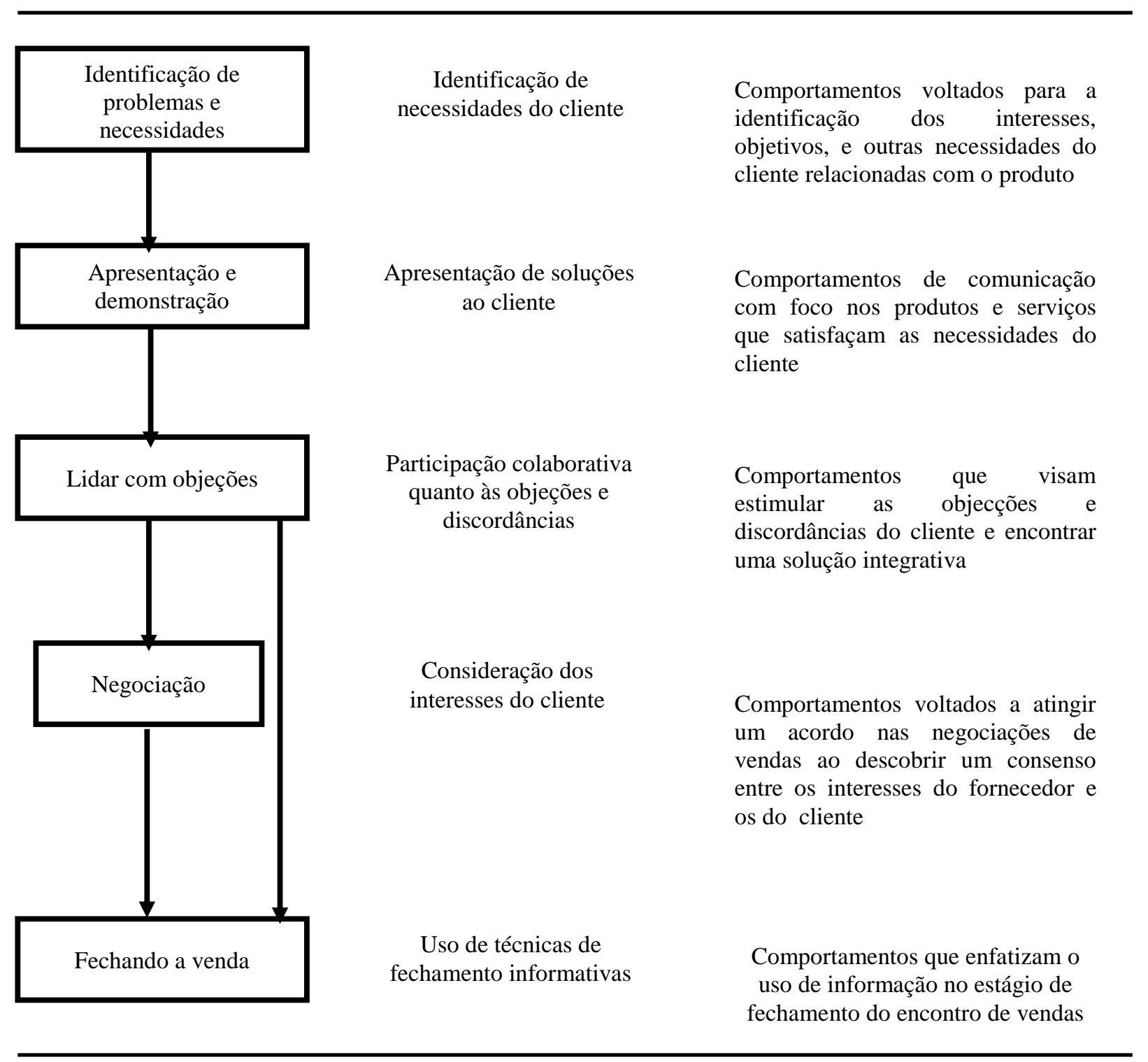

Fonte: Homburg et al (2011, p. 56, tradução nossa).

No primeiro estágio, da identificação das necessidades, um desafio-chave para o vendedor é entender precisamente as demandas do cliente, ou seja, busca-se identificar os interesses, metas e outras necessidades relacionadas ao produto. No segundo estágio, da apresentação, a orientação para o cliente manifesta-se a partir da oferta de produtos que correspondam às necessidades específicas do cliente ao mesmo tempo em que the são explicitados os benefícios. No terceiro estágio, da objeção, o conflito inerente na relação cliente-vendedor 
tende a se tornar visível. Aqui, os vendedores voltados para o cliente, adotam uma abordagem colaborativa, ao trocar informações proativamente e, de maneira criativa, identificar benefícios recíprocos. No quarto estágio, em função da abordagem colaborativa não poder ser aplicada a todos os conflitos de interesses, urge um engajamento no comprometimento com o estágio de negociação, isto é, deve se buscar um consenso negociações de vendas ao se buscar um equilíbrio entre os interesses do lojista e os do cliente. Por fim, no estágio do fechamento de vendas, ao invés de se usar técnicas de vendas persuasivas, percebidas como manipulativas pelos clientes, os vendedores devem se valer das informações.

\subsection{A imagem da loja}

A imagem da loja é conceituada por Verma (2012) como a maneira que os clientes veem a loja, isto é, suas impressões e percepções acerca da loja. Os clientes podem conceber várias associações em sua memória sobre um negócio. No contexto de lojas de varejo, tais associações referem-se à imagem da loja codificada em um quadro mental dos compradores. Esta abordagem salienta que os clientes têm suas opiniões sobre uma loja baseados em fatos, e também se sentem confiantes sobre essas opiniões. As pesquisas existentes identificam a atmosfera da loja, a conveniência, o preço/valor, a qualidade da mercadoria, a seleção e o serviço, além dos programas de incentivos de vendas como elementos centrais da imagem da loja (ORTH; GREEN, 2009; GUPTA; PIRSCH, 2008).

De acordo com Burt e Carralero-Encinas (2000), a maioria das pesquisas explora a questão da imagem concebida como a percepção do consumidor sobre a imagem global da loja, relativa a contextos específicos de comportamento de compras ou a atributos específicos da loja e serviços. Ainda segundo os autores, já existem correntes de pensamento que apontam para as questões associadas à implementação da imagem e a dissonância que pode existir entre as percepções da gerência e dos clientes quanto à imagem da loja.

A imagem corporativa da loja é definida por Verma (2012) como uma combinação da loja como marca, e a seleção das marcas próprias e dos fabricantes vendidas pelo lojista. A imagem da loja, no sentido desta como uma marca, é geralmente mensurada como as percepções dos clientes quanto ao desempenho da loja (MARTENSON (2007). A imagem corporativa relaciona-se intimamente aos fatores institucionais, entendidos como o estilo da 
loja (conservadora ou moderna), os atributos de reputação e confiabilidade. Um alto nível destes fatores sinaliza que o lojista possui mercadorias/serviços de boa qualidade porque uma boa reputação é um indicador extrínseco vital para a qualidade percebida do varejista pelos clientes. Lojas com boa reputação, alta popularidade e credibilidade atraem mais atenção, contatos e visitas de clientes potenciais. Consequentemente, o lojista com alto nível de fatores institucionais pode ser reconhecido e lembrado pelos compradores prontamente. Além disso, tal lojista criará associações varejistas mais positivas em função de proporcionar maior satisfação ao cliente (JINFENG; ZHILONG, 2009).

A imagem corporativa é baseada no que as pessoas associam à loja ou em todas as informações (percepções, inferências e crenças) acerca da loja que os compradores possuem. A imagem da loja está intimamente ligada à sua reputação. Esta, por sua vez, pode representar um sinal que resume seu comportamento pretérito e que pode ser usado para se prever ações futuras. Uma imagem favorável terá um impacto no comportamento de consumo dos clientes da loja com relação às marcas, fazendo-a cobrar preços superiores, manter clientes leais e mais engajados com a propaganda boca-a-boca. Em outras palavras, é provável que uma imagem favorável de loja aumente a satisfação dos clientes com a loja que, por sua vez, aumenta a fidelidade dos mesmos (MARTENSON, 2007.

\subsection{Prestígio da loja.}

O prestígio está relacionado ao julgamento de avaliação subjetivo sobre o elevado status social de pessoas ou objetos inanimados como marcas, por exemplo. Em relação às categorias de produtos da loja, o critério-chave para uma marca ser julgada de prestigio é seu know-how inerente e exclusivo que pode estar ligado ou a um atributo específico ou à qualidade e desempenho globais do produto. Em resumo, o prestígio é um julgamento avaliativo positivo que os consumidores formam em relação às marcas. Este julgamento pode ser influenciado por um desempenho singular inerente à marca ou por símbolos de prestígio associados à marca. (DUBOIS; CZELLAR, 2002). 
Dubois e Czellar (2002) advogam que os julgamentos sobre o prestígio feitos pelo consumidor podem emergir do sucesso tecnológico, do alto desempenho ou da natureza exclusiva de atributos específicos da marca do produto. Portanto, para eles, o marketing-mix das marcas de prestígio deve se apoiar em uma oferta extremamente diferenciada, sobretudo no que se refere à comunicação, devendo enfatizar o sucesso notável da marca.

$\mathrm{Na}$ literatura do varejo, pouco se tem trabalhado a questão da influência do prestígio da marca como um componente do valor percebido da loja pelo cliente. Este prestígio gera confiança nos clientes potenciais para comprar nestas lojas, pois eles percebem riscos menores associados à aquisição dos bens e serviços através dos sinais que estas marcas de prestígio lhes enviam. (DAWSON, 1988; BAEK et al, 2010).

Teas e Agarwal (2001) assinalaram que o valor percebido pode ser conseguido quando uma empresa tem um nome de marca forte ou goza de um prestígio superior, o que aumenta a qualidade percebida e minimiza os riscos de desempenho, ou seja, o risco de que o produto não cumpra, efetivamente, o que se propôs a fazê-lo. Na mesma linha de raciocínio, Sweeney e Soutar (2001) afirmam que o prestígio superior da marca aumenta tanto o benefício emocional quanto o social, ou seja, os consumidores acreditam que estão comprando um produto que apresenta um excelente desempenho e que é sinônimo de status.

\subsection{O local onde a loja está situada dentro do shopping center.}

Uma seleção conveniente para a localização de determinada loja ocupa o topo de prioridades das decisões gerenciais, tendo em vista que uma boa localização permite um pronto acesso e é capaz de atrair uma grande quantidade de clientes. Uma boa localização, portanto, é vital para o sucesso de uma loja. Em uma época em que as características dos bens/serviços ofertados pelas lojas tendem a ser tão próximas, mesmo sutis diferenças na localização podem impactar significativamente a lucratividade e o market share. (CRAIG et al, 1984; R. KUO et al, 2002)

Enquanto uma boa localização pode minimizar os problemas associados a certas deficiências de comercialização dos bens/serviços da loja, uma pobre localização, por outro lado, pode comprometer os resultados financeiros, tornando difícil, mesmo para um varejista experiente, 
superar este problema. Uma vez que a localização da loja tenha sido selecionada, a gerência não poderá mais rever sua decisão sem consequências financeiras significantes. Além do mais, por meio de uma localização estratégica, a loja obtém vantagens que são singulares, pois, no desenvolvimento de estratégias competitivas, os preços podem ser igualados, os serviços podem ser estendidos e melhorados, a promoção pode ser imitada, mas as vantagens decorrentes da localização da loja são difíceis de serem combatidas ou neutralizadas (ACHABAL et al, 1982).

De acordo com R. Kuo et al (2002), Mousavi e Niaki (2013), os métodos de seleção de localização de lojas mais usados são: a lista de verificação, as abordagens análogas, os modelos de regressão e os modelos de atribuição de localização:

a) O modelo de lista de verificação, a partir de vários fatores de localização que podem influenciar os lucros e os custos da loja, avalia, sistematicamente, cada uma das potenciais localizações de uma área específica, compara seus respectivos índices de adequação obtidos da avaliação e finalmente identifica a localização mais propícia ao investimento.

b) A abordagem análoga objetiva determinar a fronteira da área de negócio visada e a receita de vendas da nova localização possível de maneira a avaliar a adequação desta localização. Através deste método, o varejista tem de descobrir uma ou várias lojas similares numa primeira fase e, depois, investigar o poder de consumo destas lojas a partir de diferentes localizações e áreas.

c) O modelo de regressão tem sido aplicado em uma gama de campos. Ele, geralmente, é usado para análise de localização de varejo de maneira a determinar os principais fatores que afetam extensivamente o desempenho de uma determinada loja em termos de negócios, e também calcular o grau de influência sobre a performance para cada um destes fatores. 
d) Para equacionar o problema da localização, o modelo de atribuição de localização apregoa que um número de novas instalações devem ser colocados entre um número de clientes específicos em um área viável de tal forma que o custo total de transporte a partir das instalações até os clientes seja minimizado.

Existem vários parâmetros para se analisar a localização de lojas: competição, nível de saturação, características da loja e magnetismo, de acordo com Turhan et al (2013):

1. As lojas concorrentes devem ser levadas em conta na escolha da localização de determinada loja, tendo em vista que a competição explica a maior parte da variação na elasticidade preço entre as lojas. Seja por meio de uma concorrência direta ou indireta, a loja estará competindo pelos recursos financeiros dos possíveis compradores. Uma série de variáveis devem ser levadas em consideração quando se busca o sucesso na localização de uma loja em termos concorrenciais: a distância entre as lojas, o tamanho e o número de lojas, as alternativas de compra, atividades promocionais em comparação aos rivais, força competitiva relativa, faturamento dos concorrentes etc.

2. O nível de saturação, que pode ser definido como a razão entre a demanda de um determinado bem/serviço da loja pela oferta disponível entre os concorrentes, explica em que medida a demanda para os bens/serviços em uma área está sendo atendida pelas lojas ali presentes. Desta forma, ele deve ser levado em conta na localização de lojas, pois é um critério imperativo na atração dos clientes à loja.

3. Os varejistas devem se preocupar em verificar uma grande variedade de características de loja para ganhar competitividade ou melhor desempenho contra os seus concorrentes em determinada localidade. Com efeito, a competitividade das lojas está altamente associada às suas características específicas: facilidade de acesso, imagem de loja e custos. A facilidade de acesso, que se refere à habilidade dos clientes em descobrir a loja fácil e rapidamente, é dos fatores mais importante 
na discussão sobre localização de lojas. A imagem da loja é outro fator preponderante na localização das lojas, tendo em vista como os concorrentes são percebidos naquela área. E por fim, os custos devem ser analisados na decisão de localização por razões óbvias, incluindose aí os de construção, aluguel, compra, reforma da loja etc.

4. Entre outras variáveis, os varejistas percebem a aglomeração como um fator preponderante na decisão de localização de suas lojas. As lojas âncoras possuem o poder de aglutinar um grande número de pessoas e, por isto, são percebidas como ímãs pelos varejistas. Elas são capazes de gerar mais negócios por sua facilidade em atrair compradores potenciais mesmo de lugares mais distantes da área em que estão situadas. 
Este capítulo apresenta os procedimentos metodológicos utilizados neste estudo. Portanto, serão discutidos o método de pesquisa escolhida, a seleção dos respondentes analisados, os instrumentos de coleta de dados, o protocolo de pesquisa, as variáveis e indicadores, os instrumentos de análise de dados, e também os modelos conceitual e da validação da mesma, além de suas limitações.

\subsection{Método de pesquisa}

Andrade (1999, p. 103) define a pesquisa como "o conjunto de procedimentos sistemáticos, baseado no raciocínio lógico, que tem por objetivo encontrar soluções para problemas propostos mediante a utilização de métodos científicos".

A pesquisa qualitativa, afirma Berg (2009), procura de forma adequada responder as questões ao examinar vários ambientes sociais e os indivíduos que neles habitam. Os pesquisadores, na abordagem qualitativa, desta forma, estão mais interessados em saber como os humanos se auto organizam e como organizam seus ambientes, e como os habitantes destes ambientes extraem sentido de seus entornos através dos símbolos, rituais, estruturas sociais, papéis sociais e assim por diante. A pesquisa qualitativa, expressam Hesse-Biber e Leavy (2004), é um campo distinto de investigação que engloba ambas análises (micro e macro) sobre as formas históricas, comparativas, estruturais, observacionais e interacionais do conhecimento.

A abordagem qualitativa está calcada no que se entende por epistemologia, uma teoria do conhecimento. A epistemologia formula questões sobre como se pode saber sobre algo que conhecemos. Isto implica em perguntas que procuram descobrir quem pode ser um conhecedor, que coisas podem ser conhecidas e como o conhecimento é gerado. O processo de pesquisa tem início com perguntas e suposições, consciente ou inconscientemente formuladas, que servem como um fundamento para uma posição epistemológica. 
A pesquisa qualitativa tem como objetivo primário gerar ou construir teoria, sendo esta definida, de maneira geral, como uma descrição de um aspecto do mundo social que vai além do que é empiricamente conhecido. Gerar teoria, auxilia os pesquisadores a explicarem e a generalizarem os dados empíricos coletados durante determinado estudo a fenômenos sociais mais amplos. Neste aspecto, vale frisar que a teoria e os métodos estão intimamente ligados na pesquisa qualitativa (HESSE-BIBER; LEAVY, 2004).

Quando se usar uma abordagem qualitativa ou quantitativa? O quadro 1 mostra as principais características associadas aos dois tipos de pesquisas.

Quadro 1: Características dos paradigmas qualitativo e quantitativo.

\begin{tabular}{|c|c|}
\hline PARADIGMA QUALITATIVO & PARADIGMA QUANTITATIVO \\
\hline Preferências por avaliações qualitativas. & Preferências por avaliações quantitativas. \\
\hline $\begin{array}{l}\text { Preocupado em entender, compreender e descrever os } \\
\text { comportamentos humanos através de um quadro de } \\
\text { referência. }\end{array}$ & $\begin{array}{l}\text { Procura dos fatos e causa do fenômeno social através } \\
\text { de medições de variáveis. }\end{array}$ \\
\hline Enfoque fenomenológico e enfoque dialético. & Enfoque lógico-positivista. \\
\hline $\begin{array}{l}\text { Sistemas de descrições não controladas, observação } \\
\text { natural. }\end{array}$ & Sistemas de medições controladas. \\
\hline Subjetivo: perspectiva interior perto dos dados. & $\begin{array}{l}\text { Objetivo: perspectiva externa, distanciamento dos } \\
\text { dados. }\end{array}$ \\
\hline $\begin{array}{l}\text { Profundo: orientado para a descoberta, exploratório, } \\
\text { descritivo, indutivo. }\end{array}$ & $\begin{array}{l}\text { Superficial: } \\
\text { reducionista, baseado na inferência } \\
\text { dedutiva. }\end{array}$ \\
\hline Orientado para o processo. & Orientado para o resultado. \\
\hline Holístico: visa à síntese. & Particularizado: visa à análise. \\
\hline
\end{tabular}

Fonte: Martins e Theóphilo (2009).

O que se pretende pesquisar neste estudo é se o valor de loja percebido pelo cliente, na perspectiva dos benefícios, é uma variável importante para influenciar sua lealdade à loja. Além disso, pretende-se investigar se as variáveis imagem de loja, ambiente de loja, prestígio da loja, além de sua localização, têm influência sobre o valor de loja percebido pelo cliente. Portanto, existe uma preocupação com a compreensão e a descrição do comportamento de compras dos clientes de lojas a partir de uma perspectiva de marketing. Assim, optou-se, para este estudo, pela pesquisa qualitativa. 
As pesquisas podem ser classificadas, quanto aos objetivos, em exploratória, descritiva e causal (ANDRADE, 1999; GIL, 2002; HAIR JR. et al, 2005). Um projeto de pesquisa exploratório é indicado quando as questões de pesquisas são imprecisas ou quando a teoria disponível é incipiente. A pesquisa exploratória mostra-se útil para se conhecer melhor o problema de pesquisa (GIL, 2002; HAIR JR. et al, 2005). Segundo Andrade (1999) e Gil (2002), este tipo de pesquisa presta-se a definir os objetivos ou formular as hipóteses para serem testadas em estudos posteriores. Este estudo pretende construir hipóteses que possam, futuramente, serem confirmadas ou não, através de pesquisas quantitativas, o que o caracteriza como exploratório. Nos estudos de caráter exploratório, como o que se segue, a hipótese de trabalho, embora não necessite de explicitação formal, torna-se factível para que a pesquisa apresente resultados satisfatórios, isto é, atinja um nível de interpretação mais acurado (MARCONI; LAKATOS, 2010)

Os métodos de pesquisa referem-se às técnicas ou ferramentas utilizadas pelos pesquisadores para se coletar e se interpretar os dados (BERG, 2009). Sempre que a abordagem metodológica ou o tipo de estudo envolver análises de informações, dados e evidências empíricas, o pesquisador deverá valer-se de técnicas de coleta necessárias ao desenvolvimento e conclusões de sua pesquisa. Dependendo das características e do tema investigado, o pesquisador acaba ou por enfatizar a avaliação quantitativa (mensurando ou medindo variáveis) ou a qualitativa (buscando descrever, compreender e explicar comportamentos, discursos e conjunturas). As principais técnicas de pesquisa exploratória são, além da revisão da literatura, a observação, a observação participante, a pesquisa documental, o painel, laddering, os questionários, os grupos de foco, as entrevistas, a técnica Delphi e as técnicas projetivas, de acordo com Hair Jr. et al (2005), Martins e Theóhilo (2009). Neste estudo, optou-se pelas entrevistas semiestruturadas.

\subsection{Discurso do sujeito coletivo}

A discussão sobre os aspectos técnicos da pesquisa baseia-se, segundo Martins e Theóphilo (2009), na concepção de delineamento, ou seja, nos meios técnicos de investigação. Corresponde, portanto, ao planejamento e estruturação da pesquisa em seu aspecto mais amplo, envolvendo desde a diagramação, passando pela previsão de coleta, até a análise de 
informações, dados e evidências. Os autores advogam que, pelo delineamento estar muito fortemente associado às pesquisas com planejamento rígido, típico das ciências naturais, o termo estratégias de pesquisa seria mais plausível para se referir às diferentes maneiras de investigar e analisar dados empíricos oriundos das ciências sociais aplicadas.

Dentre as estratégias de pesquisa (delineamentos), encontramos o Discurso do Sujeito Coletivo (DSC), desenvolvida pelos professores Fernando Lefevre, Ana Maria Cavalcanti Lefevre e Jorge Juarez Vieira Teixeira, todos da Faculdade de Saúde Pública da Universidade de São Paulo (FSP/USP). A premissa, aqui, é que seja construída uma síntese dos pensamentos encadeados discursivamente sobre o tema investigado a partir do leque de respostas dos entrevistados. O somatório destes discursos traduz-se nas representações sociais - entidades sociais multifacetadas que respondem por uma série de funções com a finalidade de guiar, orientar e justificar ações cotidianas sobre o tema estudado (MARTINS; THEÓPHILO, 2009).

Segundo Lefevre e Lefevre (2012), no DSC passa a não existir mais a falsa dicotomia entre o qualitativo e o quantitativo, pois se trata de um método essencialmente qualiquantitativo, tendo em vista que, em todos os momentos da pesquisa, do princípio ao fim, permanece intacta a natureza essencialmente discursiva e qualitativa da opinião ou representação e, inseparável dela, o aspecto quantitativo, associado à representatividade e generalização dos resultados. Ainda segundo os autores, isto ocorre porque o DSC é o desdobramento natural do raciocínio lógico de que, como em qualquer sociedade os indivíduos trocam ideias, opiniões, crenças ou representações, a expressão dessas opiniões compartilhadas poderia absorver "a reunião em discursos-síntese dos conteúdos e argumentos que conformam essas opiniões semelhantes (LEFEVRE; LEFEVRE, 2012, p. 17).

O total destas representações, por sua vez, pode ser definido como o imaginário existente sobre o tema investigado. As representações sociais podem ser compreendidas como a expressão do pensamento de determinada população acerca do tema estudado. A manifestação deste pensamento pode se dar, por exemplo, através do conjunto dos discursos verbais proferidos por pessoas oriundas dessa população. Desta forma, os indivíduos pertencentes a diversos grupos sociais são inquiridos, de forma individual, para se conhecer, sistematicamente, as representações sociais acerca do assunto investigado (MARTINS; THEÓPHILO, 2009). 
Para os mesmos autores, o significado e intencionalidade surgem mais clara e naturalmente a partir dos discursos de pessoas situadas em certa posição em determinado campo social, pois elas podem ser identificáveis enquanto categoria por terem habitus ${ }^{2}$ e representações análogas, traduzidas em certas ações sociais e modalidades de discursos que as representam. Observa-se que a abordagem qualitativista do DSC permite uma compreensão mais profunda em relação aos campos sociais e aos sentidos neles existentes, permitindo interpretações e explicações quanto ao fenômeno analisado.

O DSC consiste, segundo Lefevre e Lefevre (2012), em uma série de operações a partir da matéria-prima que são os depoimentos individuais ou outro tipo de material verbal (artigos de jornais, por exemplo). Operações estas que culminam, ao fim do processo, em depoimentos coletivos, isto é, construtos gerados com estratos literais do conteúdo mais representativo dos diferentes depoimentos que apresentam sentidos parecidos. Cada um desses depoimentos coletivos ou DSCs permite veicular uma determinada e distinta opinião ou posicionamento; assim, o resultado final de uma certa pesquisa de opinião será combinado pelo número de diferentes opiniões sob a forma de DSC que existirem entre determinada população investigada.

Lefevre e Lefevre afirmam que no DSC, os depoimentos são redigidos na primeira pessoa do singular, buscando, com isso, gerar no receptor o efeito de uma opinião coletiva expressandose diretamente, como fato empírico, pela voz de um único sujeito de discurso. Sociologicamente isto é possível, advertem os autores, pois se entendem as formações sociais, de acordo com a teoria das representações de Jodelet, como entidades formadas por representações sociais na forma de discursos coletivos que os indivíduos internalizam e se apropriam. Como o DSC é formado por um número certo de depoimentos oriundos de distintos indivíduos pesquisados, cada DSC possui determinado peso, equivalente à razão de indivíduos que aderem a certa opinião, sobre o total de pesquisados. Portanto, advogam, ainda os autores, a opinião que emerge do DSC apresenta uma pertinência: qualitativa.

\footnotetext{
2 “O habitus é, portanto, um sistema de disposições, tendências incorporadas pelos atores decorrentes da especificidade do processo de socialização por eles percorrido, particularmente da sua inserção social mais objetiva em determinados campos (religioso, intelectual, científico etc.) que presidem às suas práticas sociais" (LANDINI, 2007).
} 
"Qualitativa porque no DSC, cada distinta opinião coletiva é apresentada sob a forma de um discurso (e não, por exemplo, sob a forma de escolhas de alternativas pré-fixadas de resposta, nem sob a forma de meras categorias) que recupera os distintos conteúdos e argumentos que se conformam a dada opinião na escala social ou coletiva” (LEFEVRE; LEFEVRE, 2012, p. 18).

Lefevre e Lefevre (2012), Martins e Theóphilo (2009) afirmam que a metodologia do DSC, para fazer com que, empiricamente, um conjunto de questões abertas possa gerar opiniões coletivas, precisa valer-se de alguns operadores ou figuras metodológicas como as expressões-chave, as ideias centrais, a ancoragem e o DSC, indispensáveis para se analisar e interpretar os depoimentos. Os conceitos emitidos pelos respectivos autores são apresentados abaixo:

a) Expressões-chave $(\mathrm{ECH})$ : são trechos, segmentos, contínuos ou descontínuos, do discurso a serem selecionados pelo pesquisador e que revelam a essência do conteúdo do depoimento ou discurso, ou ainda da teoria subjacente. Correspondem à literalidade das transcrições de partes dos depoimentos, correspondendo a uma espécie de análise discursivo-empírica sobre o entendimento das ideias centrais e das ancoragens identificadas nos discursos.

b) Ideias centrais (IC): nome ou expressão linguística que revela ou descreve, da maneira mais abreviada e precisa possível, o sentido ou os sentidos das ECH de cada um dos discursos analisados e de cada conjunto homogêneo de ECHs, que originará, a posteriori, o DSC. Neste último caso, a IC é denominada de categoria. A IC corresponde às afirmações evidenciadoras sobre o essencial do conteúdo do discurso. 
c) Ancoragens (AC) são expressão de uma dada teoria ou ideologia que o autor do discurso defende e que está presente em sua fala como se fosse uma afirmação qualquer. $\mathrm{Na} \mathrm{AC}$, o enunciador do discurso apropria-se de uma afirmação genérica para enquadrar uma situação particular, como por exemplo, a afirmação de que "médico que é médico".... As AC referem-se aos traços linguísticos que explicam as teorias, hipóteses, conceitos, ideologias e significações etc. presentes na sociedade e na cultura que estão internalizados nas pessoas que discursam.

d) O discurso do sujeito coletivo (DSC) é uma reunião em um só discurso-síntese, redigido na primeira pessoa do singular, de $\mathrm{ECH}$ que possui a mesma IC ou AC. Revela-se uma alternativa para superar os limites de análise das questões fechadas bem como das categorias construídas para o entendimento das respostas às perguntas abertas. O DSC busca se isolar da lógica quantitativa-classificatória, recorrendo ao resgate do discurso como signo de conhecimentos dos próprios conteúdos discursivos. As falas e manifestações dos respondentes não são reduzidas a um número ou categoria. Em vez disso, baseado nos fragmentos dos discursos individuais, pretende-se construir um dado pensar ou representação social. O que se busca é a construção de um imaginário a partir das representações sociais oriundas do DSC, isto é, o discurso de todos como se fosse um discurso unitário.

A forma como os depoimentos são organizados é orientada pela análise e compreensão do conteúdo do texto originado a partir das entrevistas individuais, buscando identificar as diferentes ideias centrais e suas respectivas expressões-chave. Os DSCs são, na verdade, o cômputo total das ideias centrais e/ou suas respectivas expressões-chave expressas pelos entrevistados. Entende-se que o pensamento comunitário se revela mais claramente por meio do conjunto dos discursos presentes nessa comunidade sobre uma dada representação social. O conteúdo do DSC é formado pelo discurso individual de um certo depoente e também pelo que poderia ter reportado e não o fez, mas que seu companheiro de coletividade atualizou por ele, pois o pressuposto sociológico básico é que o DSC é a representação simbólica do campo 
social a que ambos estão inseridos, e da posição que ocupam nesse campo ou nessa cultura organizacional. Em outras palavras, o DSC equivale a uma coletividade do discurso, ou seja, os depoentes que pertencem à coletividade geradora da representação social acabam por se incorporar em um dos vários fragmentos que fazem parte do discurso do sujeito coletivo (MARTINS; THEÓPHILO, 2009).

\subsection{Coleta e fonte de dados}

As entrevistas tendem a valorizar a presença do pesquisador, facilitando ao depoente alcançar a liberdade e a espontaneidade vitais à captação das dimensões almejadas na investigação. Há que se frisar, devido ao aspecto peculiar do discurso de cada depoente, a imprescindível seleção de diversas e variadas entrevistas, buscando se compor um horizonte global, o discurso coletivo, a fim de que sejam atingidas a compreensão e interpretação do objeto sob inquirição (MARTINS; THEÓPHILO, 2009).

Em relação às suas estruturas, as entrevistas podem ser classificadas como padronizadas (formal ou estruturada), não padronizada (informal ou não diretiva), e a semipadronizada (guiada por semiestruturação ou focada). A grande diferença entre estas estruturas de entrevistas reside no grau de rigidez com relação à estrutura de apresentação, dentro de um contínuo de formalidade, conforme quadro 2 abaixo:

Quadro 2: Contínuo da estrutura de formalidade da entrevista

\begin{tabular}{|c|c|c|}
\hline Entrevistas padronizadas & Entrevistas semipadronizadas & Entrevistas não padronizadas. \\
\hline Mais formalmente estruturada. & Mais ou menos estruturada. & Completamente desestruturada. \\
\hline $\begin{array}{l}\text { Nenhum desvio na ordem das } \\
\text { perguntas. }\end{array}$ & $\begin{array}{l}\text { As questões podem reordenadas } \\
\text { durante a entrevista. }\end{array}$ & $\begin{array}{l}\text { Nenhuma definição de ordem } \\
\text { para as perguntas. }\end{array}$ \\
\hline $\begin{array}{l}\text { A redação de cada pergunta deve } \\
\text { ser feita exatamente como ela está } \\
\text { escrita. }\end{array}$ & A redação das questões é flexível. & $\begin{array}{l}\text { Nenhuma definição de redação } \\
\text { para as perguntas. }\end{array}$ \\
\hline $\begin{array}{l}\text { Nenhum ajuste no nível de } \\
\text { linguagem. }\end{array}$ & $\begin{array}{l}\text { O nível da linguagem pode ser } \\
\text { ajustado. }\end{array}$ & $\begin{array}{l}\text { O nível de linguagem pode ser } \\
\text { ajustado. }\end{array}$ \\
\hline $\begin{array}{l}\text { Nenhum esclarecimento ou } \\
\text { resposta às perguntas sobre a } \\
\text { entrevista. }\end{array}$ & $\begin{array}{l}\text { O entrevistador pode responder } \\
\text { perguntas e fazer esclarecimentos. }\end{array}$ & $\begin{array}{l}\text { O entrevistador pode responder as } \\
\text { perguntas e fazer esclarecimentos. }\end{array}$ \\
\hline $\begin{array}{l}\text { Nenhuma questão adicional pode } \\
\text { ser adicionada. }\end{array}$ & $\begin{array}{l}\text { O entrevistador pode adicionar ou } \\
\text { deletar questões entre temas } \\
\text { subsequentes. }\end{array}$ & $\begin{array}{l}\text { O entrevistador pode adicionar ou } \\
\text { deletar questões entre as } \\
\text { entrevistas. }\end{array}$ \\
\hline $\begin{array}{l}\text { Similar, em formato, a um } \\
\text { questionário escrito. }\end{array}$ & & \\
\hline
\end{tabular}

Fonte: Berg (2009, p. 105, tradução nossa). 
Entre os vários métodos de coleta de dados, no DSC, de abordagem qualitativa, a aplicação de entrevistas semiestruturadas geralmente é a que permite, por meio dos discursos dos depoentes, acessar dados da realidade de matiz subjetivo, quais sejam: ideias, crenças, opiniões, sentimentos, comportamentos etc. A entrevista, para Berg (2009), pode ser conceituada, simplesmente, como uma conversação, com uma finalidade; qual seja, a de coletar informações.

As entrevistas semiestruturadas caracterizam-se, segundo Flick (2004), por questões mais ou menos abertas que devem ser levadas à inquirição na forma de um guia de entrevista, esperando-se que estas questões possam ser respondidas livremente pelo depoente. Ainda segundo o autor, a fim de se evitar problemas quanto aos aspectos subjetivos dos tópicos relevantes (como o de mediação entre os inputs do guia da entrevista e os objetivos da questão de pesquisa, por um lado, e modo de apresentação do depoente, por outro), o entrevistador pode e deve, durante a entrevista, optar por quando e em que sequência fazer as perguntas. $\mathrm{O}$ termo semiestruturado refere-se ao modo de conduta efetiva da entrevista, em que se busca conciliar a menção a certos tópicos presentes no roteiro de entrevistas e aqueles sugeridos pelos entrevistados por acreditarem ser relevantes. Se os enunciados concretos são o que se buscam na coleta de dados, então, possivelmente, a pesquisa semiestruturada será a opção mais viável economicamente.

Os dados coletados são primários, extraídos diretamente das fontes pesquisadas. Como técnicas de coleta de dados foram usadas as entrevistas semiestruturadas, a partir de um roteiro de perguntas previamente definidas e igualmente aplicados a todos os entrevistados, quais sejam, consumidores de lojas situadas em shopping centers. As perguntas foram do tipo abertas de maneira a permitir a livre manifestação sobre o comportamento de compras dos entrevistados. Os entrevistados responderam as questões solicitadas de maneira livre, sem a intervenção do entrevistador, a fim de se evitar viés na pesquisa. Vale destacar que foram realizadas entrevistas pré-testes para dez (10) clientes fiéis a lojas situadas em shopping centers como forma de se verificar se efetivamente as perguntas presentes no roteiro de entrevistas estavam sendo compreendidas pelos respondentes. Isto é fundamental para que as respostas realmente se adequem aos objetivos propostos, de acordo com Lefevre e Lefevre (2012). 
Os potenciais respondentes foram contatados via $e$-mail ou telefone para saberem do interesse em participar da pesquisa. A condição sine qua non para que eles fossem qualificados para participar da pesquisa é que fossem fiéis à determinada loja, ou seja, que considerassem sempre algumas lojas em seu conjunto de escolha quando de suas atividades de compra. $\mathrm{O}$ roteiro de entrevista e o convite por e-mail estão nos apêndices. Os depoimentos foram gravados de forma individual, obedecendo ao ordenamento das perguntas elencadas no roteiro de entrevistas. Além disso, o entrevistador, sempre que necessário, buscou estimular o entrevistado a falar um pouco mais sobre determinada questão a fim de extrair, ao máximo, as percepções e pontos-de-vista dos respondentes. A questão de número 1 foi utilizada como forma de garantir que o respondente realmente fosse fiel a uma determinada loja. O local das entrevistas variou de acordo com a disponibilidade dos entrevistados, sendo realizado no lar do entrevistador ou do entrevistado.

$\mathrm{O}$ roteiro de entrevista está ilustrado no quadro 3 abaixo, relacionando cada pergunta às hipóteses de trabalho traçadas nesta pesquisa. Para não comprometer a qualidades das respostas, e para facilitar entendimento dos temas cobertos pelos dos respondentes, os conceitos foram inseridos em uma linguagem acessível para os entrevistados, embutidos em situações corriqueiras de experiências de compra em lojas.

Quadro 3: Questões associadas às hipóteses de trabalho

\begin{tabular}{|c|c|c|}
\hline Ordem & Questão & Hipóteses de trabalho \\
\hline 1 & $\begin{array}{l}\text { Mariana compra regularmente e preferencialmente na mesma loja, } \\
\text { além de recomendá-la para outras pessoas. Você se vê como a } \\
\text { Mariana? Por quê? }\end{array}$ & \\
\hline 2 & $\begin{array}{l}\text { Em sua opinião, a música-ambiente da loja é um benefício para o } \\
\text { cliente? }\end{array}$ & \multirow{2}{*}{$\begin{array}{l}\text { Os fatores ambientais agregam } \\
\text { valor percebido pelo cliente, } \\
\text { sendo muito importante para sua } \\
\text { fidelização à loja. }\end{array}$} \\
\hline 3 & $\begin{array}{l}\text { Em sua opinião, a iluminação dentro da loja é um benefício para o } \\
\text { cliente? }\end{array}$ & \\
\hline 4 & $\begin{array}{l}\text { O layout de loja diz respeito à forma como os produtos, gôndolas } \\
\text { e corredores são organizados. Também inclui a concepção do } \\
\text { espaço e a alocação, o agrupamento e a colocação da mercadoria. } \\
\text { Você acredita que o layout da loja é um benefício para seus } \\
\text { clientes? Por quê? }\end{array}$ & \multirow[t]{2}{*}{$\begin{array}{l}\text { Os fatores de design da loja } \\
\text { agregam valor percebido pelo } \\
\text { cliente, sendo muito importantes } \\
\text { para sua fidelização à loja. }\end{array}$} \\
\hline 5 & $\begin{array}{l}\text { Você acredita que a disponibilidade de mercadorias é um } \\
\text { benefício relevante para o cliente optar por uma loja? Por quê? }\end{array}$ & \\
\hline 6 & $\begin{array}{l}\text { Você acredita que a presença dos vendedores na loja é um fator } \\
\text { relevante para sua decisão em comprar lá? }\end{array}$ & $\begin{array}{l}\text { Os fatores sociais da loja } \\
\text { agregam valor percebido pelo } \\
\text { cliente, sendo muito importantes }\end{array}$ \\
\hline
\end{tabular}




\begin{tabular}{|c|c|c|}
\hline & & para sua fidelização à loja. \\
\hline 7 & $\begin{array}{l}\text { A imagem corporativa está relacionada à impressão que os } \\
\text { clientes têm sobre a qualidade das mercadorias e do nível dos } \\
\text { serviços da loja (assistência técnica, garantia oferecida, política de } \\
\text { trocas etc.). Você acredita que a imagem exerce alguma influência } \\
\text { sobre a decisão de compra destes clientes? }\end{array}$ & $\begin{array}{l}\text { A imagem corporativa da loja } \\
\text { agrega valor percebido pelo } \\
\text { cliente, sendo relativamente } \\
\text { importante para sua fidelização à } \\
\text { loja. }\end{array}$ \\
\hline 8 & $\begin{array}{l}\text { Renato afirma que a loja } \mathrm{ABC} \text { possui certo prestígio em função de } \\
\text { seu tempo de existência no mercado. Você acredita que este } \\
\text { prestígio é um elemento importante para se comprar nesta loja? } \\
\text { Por quê? }\end{array}$ & $\begin{array}{l}\text { O prestígio da loja agrega valor } \\
\text { percebido pelo cliente, sendo } \\
\text { relativamente importante para } \\
\text { sua fidelização à loja. }\end{array}$ \\
\hline 9 & $\begin{array}{l}\text { O local dentro do shopping center onde a loja está situada tem } \\
\text { alguma influência sobre sua decisão em comprar em determinada } \\
\text { loja? }\end{array}$ & $\begin{array}{l}\text { O local onde a loja está situada } \\
\text { no shopping agrega valor } \\
\text { percebido pelo cliente, sendo } \\
\text { relativamente importante para } \\
\text { sua fidelização à loja. }\end{array}$ \\
\hline 10 & $\begin{array}{l}\text { Paulo compra na loja “ABC" porque, na sua avaliação, os } \\
\text { benefícios de loja obtidos (ambiente, imagem, prestígio e } \\
\text { localização) são maiores do que os esforços prévios (monetários e } \\
\text { não monetários) que ele tem para comprar lá. Você acredita que } \\
\text { esta situação é capaz de tornar Paulo fiel à loja? }\end{array}$ & $\begin{array}{l}\text { O valor percebido pelo cliente, a } \\
\text { partir da ótica dos benefícios, } \\
\text { leva-o à fidelização em relação à } \\
\text { loja. }\end{array}$ \\
\hline
\end{tabular}

Fonte: elaborado pelo autor (2015)

\subsubsection{Seleção e descrição dos respondentes}

Com a proposta de reconstruir os multifacetados discursos presentes no campo social analisado, a seleção dos indivíduos, de acordo com Lefevre e Lefevre (2012), deve considerar a quantidade, a variabilidade e a qualidade dos sujeitos a serem inquiridos no que se refere à possibilidade de fornecerem informações ricas, interessantes e suficientes para compor e reconstruir o DSC. Optamos por estudar o problema de pesquisa a partir de diferentes visões de clientes com distintos perfis sociais, geodemográficos, tornando essa amostra representativa não em função das quantidades dos entrevistados, mas por sua variabilidade na composição da sociedade, conforme tabela 4 abaixo. 
Tabela 4: Características sociais e geodemográficas dos respondentes

\begin{tabular}{|c|c|c|c|c|c|}
\hline Nome & Sexo & Idade (anos) & $\begin{array}{l}\text { Renda Mensal } \\
\qquad(\mathrm{R} \$)\end{array}$ & Profissão & Bairro \\
\hline Aldo Brunhara & Masculino & 35 & 5000 & Engenheiro & Perdizes \\
\hline Bárbara Semensato & Feminino & 30 & 4000 & Administradora & Pinheiros \\
\hline Davi Pelegrini & Masculino & 28 & 3500 & Administrador & Interlagos \\
\hline Flávia Simonatti & Feminino & 30 & 5000 & Psicóloga & Morumbi \\
\hline Hana Rafaele & Feminino & 30 & 3000 & Administradora & $\begin{array}{l}\text { Praça } \\
\text { Árvores }\end{array}$ \\
\hline Helga Weiss & Feminino & 50 & 4000 & Secretária Bilíngue & Morumbi \\
\hline Hudson Bessa & Masculino & 45 & 6000 & Economista & Brooklin \\
\hline Ivan Ferraz & Masculino & 35 & 3500 & Economista & Pinheiros \\
\hline Ivan Ferreira & Masculino & 29 & 3000 & Administrador & Santo Amaro \\
\hline Ivete Rolim & Feminino & 60 & 5000 & Contadora & Santa Cecília \\
\hline Jackeline Ferreira & Feminino & 34 & 3500 & Biblioteconomista & Belém \\
\hline João Luís & Masculino & 40 & 4000 & Administrador & Pinheiros \\
\hline José Santos & Masculino & 48 & 3000 & Historiador & Santo Amaro \\
\hline Juliana Maciel & Feminino & 32 & 5000 & Arquiteta & $\begin{array}{l}\text { Praça da } \\
\text { Árvore }\end{array}$ \\
\hline Kátia Santos & Feminino & 43 & 3000 & Enfermeira & Santo Amaro \\
\hline Luiz Augusto & Masculino & 39 & 5000 & $\begin{array}{c}\text { Professor } \\
\text { Universitário }\end{array}$ & $\begin{array}{c}\text { Chácara } \\
\text { Santo } \\
\text { Antônio }\end{array}$ \\
\hline Marcos Pereira & Masculino & 40 & 4000 & $\begin{array}{c}\text { Funcionário } \\
\text { Público }\end{array}$ & Pinheiros \\
\hline Maria das Neves & Feminino & 30 & 3000 & Pedagoga & Butantã \\
\hline Maria Euni & Feminino & 45 & 5000 & Advogada & Morumbi \\
\hline Nanci Prieto & Feminino & 50 & 4000 & Pedagoga & Butantã \\
\hline Natália Petrícia & Feminino & 29 & 3000 & Designer & $\begin{array}{l}\text { Praça da } \\
\text { Árvore }\end{array}$ \\
\hline Natália Servo & Feminino & 32 & 3500 & $\begin{array}{c}\text { Assessora de } \\
\text { eventos }\end{array}$ & Pinheiros \\
\hline Neiver Gonçalves & Masculino & 36 & 3000 & Bancário & Interlagos \\
\hline Omar Pontes & Masculino & 45 & 6000 & Economista & Vila Mascote \\
\hline Roberto Falcão & Masculino & 35 & 4000 & Administrador & Pinheiros \\
\hline
\end{tabular}




\begin{tabular}{|l|l|l|l|l|l|}
\hline Sérgio Salazar & Masculino & 50 & 4500 & $\begin{array}{c}\text { Professor } \\
\text { Universitário }\end{array}$ & Vila Mascote \\
\hline
\end{tabular}

Fonte: elaborado pelo autor

Optamos por trabalhar com grupos distintos de respondentes entre homens e mulheres das classes B e C, obedecendo ao critério BRASIL, da Associação Brasileira de Empresas de Pesquisa (ABEP, 2015), cujo modelo encontra-se no anexo. Os respondentes são clientes frequentes de lojas situadas dentro de shopping centers, que apresentam graus elevados de preferência por determinada loja e que a indicam para outras pessoas. Os respondentes foram escolhidos das diversas áreas geográficas da cidade de São Paulo.

\subsection{Variáveis e indicadores}

O quadro 4 apresenta os construtos utilizados para a definição do problema de pesquisa e para a geração das hipóteses de trabalho, bem como os autores consultados para a sua operacionalização, a partir dos quais foram gerados os roteiros de entrevista.

\section{Quadro 4-Construtos e indicadores}

\begin{tabular}{|c|c|c|c|}
\hline Problema de pesquisa. & Hipóteses de trabalho. & $\begin{array}{c}\text { Construtos e } \\
\text { variáveis. }\end{array}$ & $\begin{array}{c}\text { Operacionalização } \\
\text { (referências) }\end{array}$ \\
\hline \multirow{6}{*}{$\begin{array}{l}\text { O valor percebido pelo } \\
\text { consumidor, } \\
\text { perspectiva } \\
\text { benefícios, é elemento } \\
\text { relevante para sua } \\
\text { fidelização a uma loja } \\
\text { situada dentro de um } \\
\text { shopping? }\end{array}$} & \multirow[t]{2}{*}{$\begin{array}{l}\text { H1: O valor percebido de loja, na } \\
\text { perspectiva dos benefícios é uma } \\
\text { variável determinante para a } \\
\text { fidelização do consumidor à loja. }\end{array}$} & $\begin{array}{l}\text { Valor percebido de } \\
\text { loja na perspectiva } \\
\text { dos benefícios }\end{array}$ & $\begin{array}{l}\text { Zeithaml (1988), Wang } \\
\text { et al (2004), e Y. Kuo et } \\
\text { al (2009) Y. Kuo et al } \\
\text { (2009) }\end{array}$ \\
\hline & & Lealdade à loja & $\begin{array}{l}\text { Majumdar (2005); Omar } \\
\text { et al (2010). }\end{array}$ \\
\hline & \multirow{4}{*}{$\begin{array}{l}\text { H2: o ambiente de loja situada em } \\
\text { um shopping é uma variável } \\
\text { determinante na geração de valor } \\
\text { de loja percebido pelo cliente, } \\
\text { sendo muito importante para sua } \\
\text { fidelização à loja. }\end{array}$} & Música & $\begin{array}{l}\text { Mohan et al (2013. } \\
\text { Singh e Prashar (2013) }\end{array}$ \\
\hline & & Iluminação & $\begin{array}{l}\text { Mohan et al, 2013). } \\
\text { Singh e Prashar (2013) }\end{array}$ \\
\hline & & Layout & $\begin{array}{l}\text { Van Rompay et al } \\
\text { (2012); Mohan et al } \\
\text { (2012). }\end{array}$ \\
\hline & & $\begin{array}{l}\text { Disponibilidade de } \\
\text { mercadoria na loja }\end{array}$ & Levy e Weitz (2012). \\
\hline
\end{tabular}




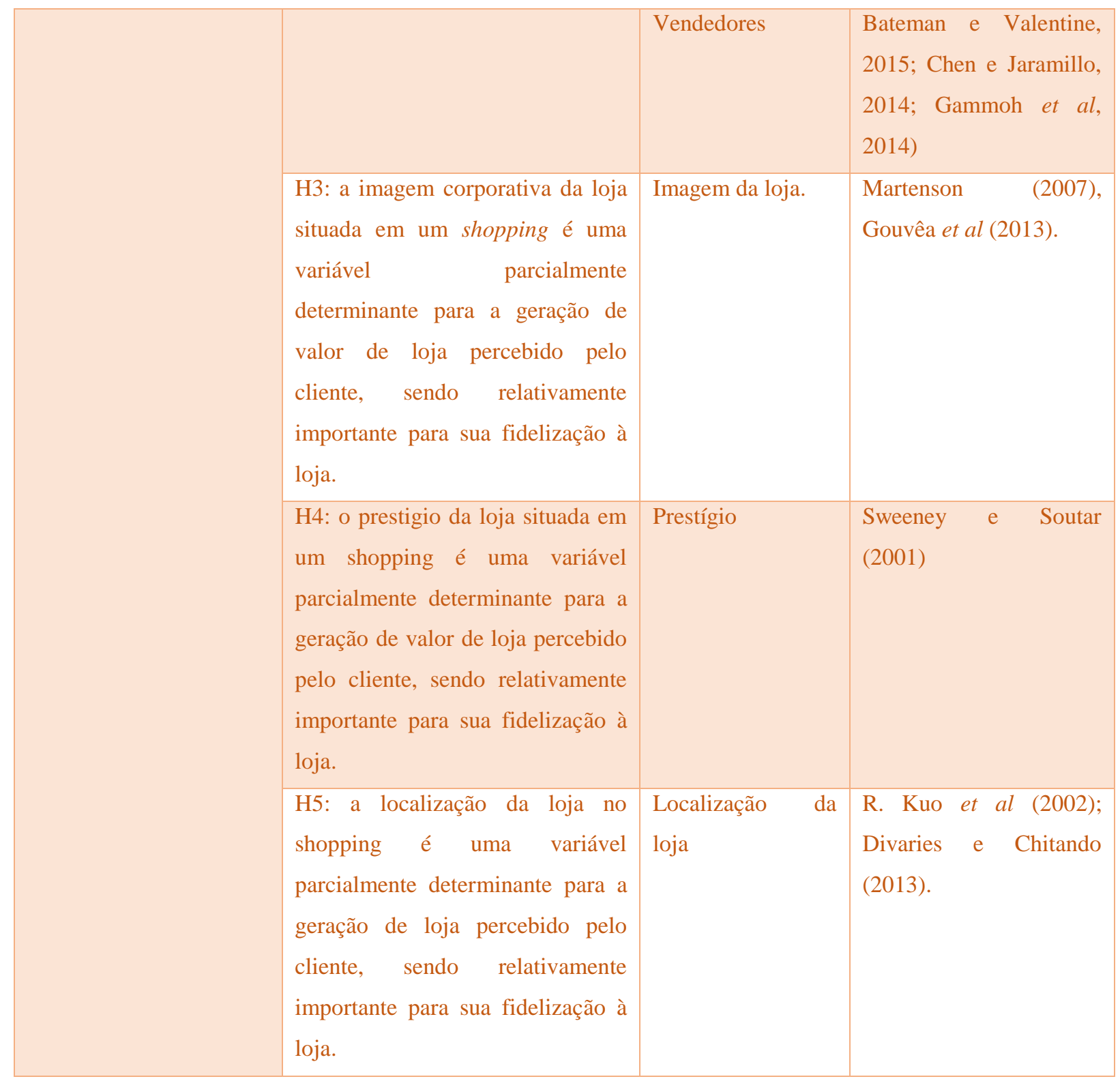

Fonte: elaborado pelo autor (2015).

\subsection{Análise dos dados}

A organização e a análise das respostas dadas ao tema central desta pesquisa, bem como aos objetivos secundários, ou seja, se o valor percebido pelo cliente, na ótica dos benefícios, é capaz de torná-lo fiel à loja localizada em shopping centers, seguiu os procedimentos de análise qualitativa conhecida como Análise do Discurso do Sujeito Coletivo (DSC). O DSC é uma metodologia que traça uma maneira sistemática para se identificar as representações sociais de grupos específicos em relação aos temas apresentados. O que se busca, através do DSC, é a construção de discursos-síntese, a partir dos discursos individuais, necessários para ilustrar um determinado tema (LEFEVRE; LEFEVRE, 2012). 
O procedimento metodológico do DSC consiste na identificação das ideias centrais e expressões-chave análogas vistas nos depoimentos dos entrevistados e, a partir daí, na composição de um discurso-síntese para cada ideia central diversa, escrito na primeira pessoa do singular. Ao final, espera-se produzir no leitor a percepção de um discurso real de alguém concreto, visando configurar "um sujeito coletivo de um discurso que revela uma determinada opinião ou representação coletiva a respeito de um tema". Quando o sujeito coletivo se expressa na primeira pessoa, recurso metodológico desenvolvido pelo DSC, busca-se revelar, de maneira concreta que os pensamentos individuais são também o resultado do pensamento coletivo que se manifesta em cada um destes indivíduos (FALCÃO; FARIA, 2007, p. 341).

A análise dos discursos centrou-se nos aspectos metodológicos da ideia central, das expressões-chave e do Discurso do Sujeito Coletivo. As trinta entrevistas selecionadas para a amostra foram transcritas em meio digital a partir do software Word 2016 e analisadas, a seguir, com o auxílio do software QualiQuantiSoft ${ }^{\circledR}$, concebido para oferecer suporte ao DSC. A análise obedeceu, então, aos seguintes passos: no primeiro, logo que as entrevistas foram transcritas fielmente no Word 2016, fez-se uso do Instrumento de Análise de Discurso (IAD1). Por meio deste instrumento, foram coletadas todas as representações socais de cada cliente fiel à loja situada em um shopping, detalhando as ideias centrais e as respectivas expressões-chave geradas de cada um destes clientes. Posteriormente, foram assinaladas todas as ideias centrais de cada evento, juntas às suas expressões-chave no Instrumento de Análise de Discurso (IAD2). Este instrumento fornece uma visão preliminar do DSC. Finalmente, o IAD2 é convertido em um discurso concatenado como se existisse somente um indivíduo que fala, representando um discurso-síntese de todos os indivíduos que presentes no sujeito coletivo. Cada DSC teve uma denominação para poder espelhar mais precisamente os pensamentos equivalentes presentes nestes discursos (LEFEVRE; LEFEVRE (2012). 


\subsection{Modelo conceitual e hipóteses de trabalho}

Este trabalho buscar verificar qual a percepção dos clientes de lojas situadas em shopping centers em relação ao valor percebido por eles, sob a visão de benefícios, como um antecedente de sua lealdade à loja situada dentro de um shopping. Também se procura saber a opinião destes clientes sobre se o ambiente de loja, sua imagem, seu prestígio e o local onde ela está situada no shopping center contribuem para a formação do valor percebido por estes compradores. A figura 8 apresenta o modelo conceitual e as hipóteses de trabalho.

Figura 8: modelo conceitual e hipótese de trabalho

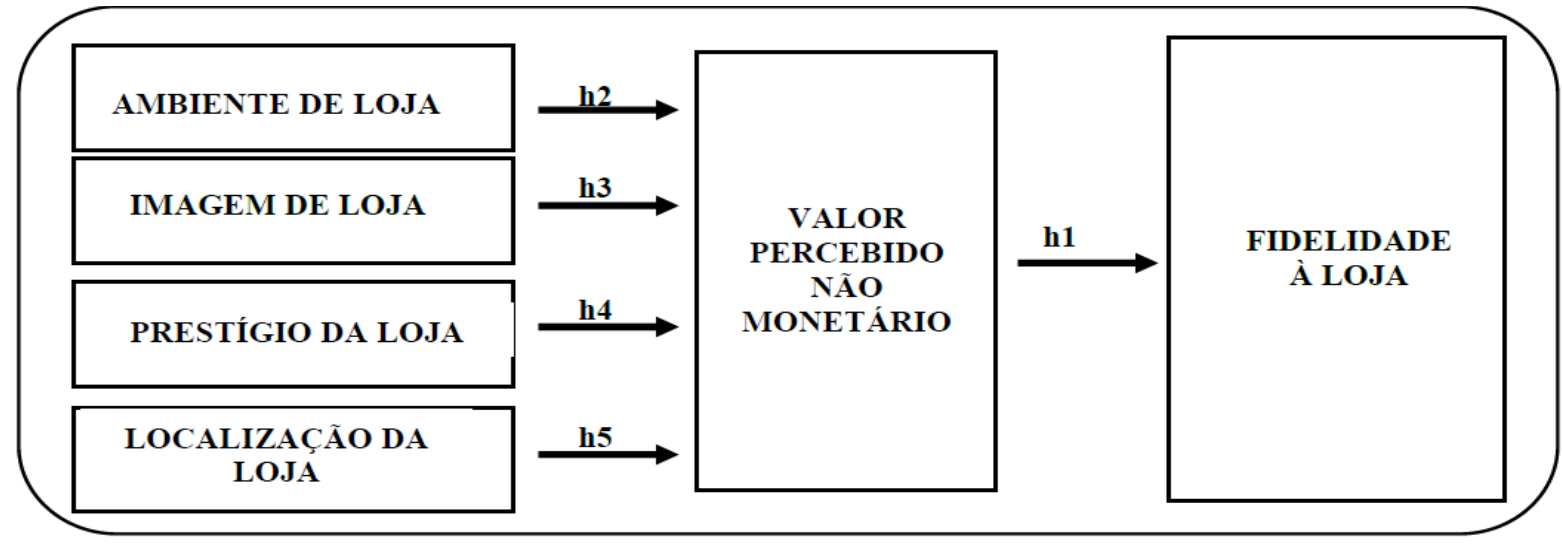

Fonte: elaborado pelo autor (2015).

3.6.1 $\mathrm{O}$ valor percebido pelo cliente como fator relevante para sua fidelização à loja.

O valor percebido de loja é uma variável importante para se analisar a fidelidade do cliente à loja, pois, inclui, em sua formação, outros custos de ordem não monetária, como os associados ao tempo, à busca, à imagem da loja e à conveniência. Portanto, a combinação de ambos os custos, monetário e não-monetário, formam o sacrifício global percebido pelo cliente, o que, por sua vez, afeta-lhe sua percepção sobre o valor percebido (PETRICK, 2002).

O valor percebido tem adquirido uma importância crucial no estudo do comportamento de compras do consumidor em função de sua função dual, ou seja, ele exerce uma influência tanto no nível de pré quanto no de pós compra, visto que ele afeta a satisfação do cliente da loja, sua disposição em recomendá-la a outros potenciais clientes, além de sua disposição em continuar comprando daquele lojista. 
O valor não monetário de loja percebido é a avaliação, por parte dos clientes, dos benefícios não monetários advindos de sua experiência de compra com a loja, com base em seus sacrifícios prévios para comprar lá. Desta forma, identifica-se a hipótese de trabalho referente ao objetivo geral:

- H1: o valor percebido pelo cliente é uma variável determinante de sua lealdade à loja situada em um shopping.

\subsection{2 $O$ ambiente de loja como meio de agregação de valor percebido pelo cliente.}

O ambiente de loja, definido como o entorno da loja, é formado de muitos elementos, entre os quais se incluem a música, a iluminação, o layout, a sinalização e os elementos humanos (funcionários, por exemplo). Ele pode ser divido em interno e externo, ou seja, o interior e o exterior de uma loja. Os elementos do ambiente de loja influenciam o comportamento de compras dos clientes através de seus efeitos, imediatos ou não, sobre a emoção, a cognição e o estado fisiológico destes compradores (LAM, 2001; RY et al (2002)

Os estudos sobre o ambiente de varejo concentram-se, basicamente, na ótica do humor do cliente: Babin e Attaway (2000) apontaram que o ambiente de loja, como é formatado, pode atrair ou repelir clientes potenciais, pois eles podem se sentir animados, felizes e satisfeitos por um lado, mas também entediados, irritados ou desmotivados por outro. Os autores ainda descobriram que um bom ambiente de loja contribui para que os clientes sintam um sentimento positivo em relação às lojas, aumentando sua repetição de compras. Neste estudo ficou demonstrado que o ambiente de loja agradável, além de influenciar os clientes dentro da loja, pode auxiliar a construir uma base contínua de aquisição de novos compradores quando gera neles sensações, percepções ou sentimentos positivos apreendidos cognitivamente.

Quartier e Van Cleempoel (2008) assinalam que a criação de um ambiente único, pelos lojistas, torna-se cada vez mais necessário para atrair e manter o cliente, uma vez que suas experiências positivas de compra os levarão à satisfação, tornando-os fiéis no longo prazo. Os autores ainda afirmam que o ambiente de loja, se visto como uma experiência de compra negativa, pode trazer consequências desastrosas, tendo em vista o êxodo destes clientes potenciais para as lojas concorrentes. Para estes autores, o ambiente de loja aprazível ajuda o 
cliente a permanecer mais tempo na loja, o que aumenta a probabilidade de que venha a comprar algo. O ambiente, para Kotler e Keller (2006), é um aspecto fundamental para as lojas: o espaço físico das lojas deve facilitar a livre movimentação dos clientes em seu interior; da mesma forma, a loja deve se valer de um ambiente planejado adequado às necessidades de seu público-alvo, sendo capaz de atrair clientes e lhes favorecer a experiência de compras.

Em um estudo clássico sobre o comportamento de compras em lojas localizadas nos shoppings, Wakefield e Baker (1998) demonstraram que as lojas devem estimular o excitamento de seus consumidores com o processo de compra, ou seja, eles devem estar convencidos de que se trata de uma experiência prazerosa, até mesmo para os clientes impulsivos, os responsáveis pelas compras não planejadas, pois conforme verificado por Morrin e Chebat (2005), a música exerceu uma grande influência no comportamento de compras dos mesmos, estimulando-os a buscarem mais informações sobre as mercadorias expostas e as comprarem mais.

A loja deve prover um ambiente de estímulos aos seus clientes, deixando-os mais confortáveis e satisfeitos, pois, do contrário, eles buscarão, em outras lojas concorrentes, situações novas, complexas e imprevisíveis. Um ambiente de loja não envolvente acaba por fazer com que os clientes pouco ou nada a visitem e, quando o fazem, manipulem poucos produtos e saiam dela muito rapidamente. Por outro lado, um ambiente de loja bem planejado às necessidades de seus clientes, culmina por transformá-los em compradores fiéis (MORRIN; CHEBAT, 2005). Pela importância que o ambiente de loja exerce sobre a fidelidade do cliente, a seguinte hipótese de trabalho pode ser enunciada:

- H2A: a música-ambiente, que compõe o ambiente de loja situada em um shopping, é uma variável determinante para se gerar valor não monetário de loja percebido pelo cliente, sendo importante para sua fidelização à loja; e

- H2B: a iluminação interna da loja, que compõe o ambiente de loja situada em um shopping, é uma variável determinante para se gerar valor não monetário de loja percebido pelo cliente, sendo importante para sua fidelização à loja; e 
- H2C: o layout de loja, que compõe o ambiente de loja situada em um shopping, é uma variável determinante para se gerar valor não monetário de loja percebido pelo cliente, sendo importante para sua fidelização à loja; e

- H2D: a disponibilidade de mercadoria, que compõe o ambiente de loja situada em um shopping, é uma variável determinante para se gerar valor não monetário de loja percebido pelo cliente, sendo importante para sua fidelização à loja.

\subsubsection{A imagem corporativa da loja como meio de agregação de valor percebido pelo cliente.}

A imagem corporativa da loja está associada, entre outros fatores, à qualidade técnica dos seus produtos ou ao seu grau de inovação, à capacidade da loja em atender eficientemente as demandas de seus clientes, entregando-lhes os serviços prometidos fielmente nos prazos estipulados, oferecendo-lhes um horário de atendimento compatível e prestando-lhes suporte sempre que houver solicitação neste sentido (BLOEMER; RUYTER, 1998). A imagem corporativa da loja reflete o grau de confiabilidade que os seus clientes depositam em uma relação comercial. Uma boa imagem corporativa de loja propicia um nível alto de engajamento dos seus clientes, tornando-os envolvidos e interessados na manutenção de um relacionamento duradouro (KIM et al, 2013).

Para Silva et al (2013), a imagem da loja é a resultante de todas as percepções que os seus clientes têm sobre os atributos e associações da loja em suas experiências de compra ao longo do tempo. Ainda segundo os autores, a imagem é crucial para o desenvolvimento de políticas de marketing pelos gestores de loja na medida em que ela permite verificar quais atributos foram mal avaliados por seus clientes, direcionando a loja para a correção dos desvios apontados. Além disso, atributos mais valorizados devem ser, obviamente, os que devem receber maior atenção pela loja a fim de se maximizar a satisfação dos seus clientes. 
Segundo Gouvêa et al (2013), a imagem corporativa da loja é formada pelo cliente baseado em atributos que ele considera relevantes, comparando-os e classificando-os da maneira como ele os percebe. A imagem da loja, então, é construída a partir da qualidade das mercadorias, dos serviços, do nível de satisfação pós-venda, da conveniência da transação, enfim, da experiência de compra positiva patrocinada pela loja. Muito embora, na literatura e em estudos empíricos, não seja efetivamente apontada pelos clientes como um fator determinante para se gerar fidelidade à determinada loja, a imagem corporativa adquire importância na percepção de valor do cliente para sua tomada de decisão em comprar em certo estabelecimento. Por esta razão, a seguinte hipótese de trabalho pode ser tecida:

- H3: a imagem corporativa da loja situada em um shopping é uma variável parcialmente determinante para se gerar valor não monetário de loja percebido pelo cliente, sendo relativamente importante para sua fidelização à loja.

3.6.4 prestígio da loja como meio de agregação de valor percebido pelo cliente.

O prestígio da loja é um importante vetor para que os consumidores reduzam significativamente sua percepção de risco associada à compra em determinada loja (DAWSON, 1988; TEAS; AGARWAL, 2001). Uma loja de prestígio traz em si um conceito de padrão superior, agregando valor para os clientes de seus produtos (VILNAI-YAVETZ E GILBOA, 2010). Este conceito de prestígio da marca da loja, geralmente, é apontado por alguns autores - Deeter-Schmelz et al (1995) - como associado a produtos e processos inovadores e ambientes atrativos. A loja de prestígio tem um enorme poder de atrair consumidores para o shopping em geral, gerando maior volume de negócios para as demais (DES ROSIERS et al, 2011).

Na visão de Sweeney e Soutar (2001), o prestígio da loja impacta positivamente o valor percebido pelo consumidor na medida em que contribui para a sua satisfação, tanto do pontode-vista emocional (ao reduzir significativamente sua dissonância cognitiva), quanto social (ao lhe emprestar status). Dawson (1988), Teas e Agarwal (2001) afirmam que o prestígio da loja é um indicador importante para que os seus clientes possam reduzir sua percepção do 
risco de comprar naquela loja específica. Uma loja de prestígio agrega valor para seus clientes na medida em que eles desfrutam dos benefícios que uma imagem superior traz em termos de status pelo uso dos produtos da loja. (VILNAI-YAVETZ; GILBOA, 2010). A loja de prestígio tem um enorme poder de gerar tráfego para si e para seu entorno, como os shoppings (DES ROSIERS et al, 2011). Ora, a partir do que foi exposto, pode-se conjecturar, então, que as lojas com maior tempo de existência no mercado são portadoras de prestígio, pois indicam, pelo menos em tese, a confiança de seus clientes em adquirir mercadorias ali em função desta tradição. Assim, pode se definir a seguinte hipótese de trabalho:

- H4: o prestigio da loja situada em um shopping, decorrente de sua tradição de mercado, é uma variável parcialmente determinante para se gerar valor não monetário de loja percebido pelo cliente, sendo relativamente importante para sua fidelização à loja.

3.6.5 local onde a loja está situada dentro do shopping como meio de agregação de valor para o cliente.

Uma boa localização pode atrair grande número de clientes para a loja. A escolha da localização da loja é uma das decisões de marketing mais importantes a ser tomada pelos proprietários ou gestores de loja em função de demandar altos investimentos, geralmente de longo prazo. É muito difícil a recuperação destes investimentos quando esta localização tenha sido inadequadamente estabelecida (R. KUO et al, 2002; DIVARIES; CHITANDO, 2013).

A importância da localização da loja para um varejista é algo a não ser subestimado: em primeiro lugar, porque, normalmente, ela é uma das considerações mais influentes nas decisões dos clientes na escolha de uma loja. Geralmente, os clientes optam por lojas próximas às suas residências ou aos seus empregos. Em segundo, porque se a loja possui a melhor localização, isto pode se configurar como uma vantagem competitiva sustentável, tendo em vista que os concorrentes ocuparão lugares menos atrativos aos olhos dos clientes (DIVARIES; CHITANDO, 2013). 
A localização de uma loja, segundo Divaries e Chitando (2013), geralmente, exige uma ampla decisão pelo varejista em função do número de fatores a serem levados em conta: o tamanho e as características da população em torno da loja, o nível de competição, acesso aos modais de transporte, a disponibilidade de estacionamentos, o perfil das lojas próximas, os custos da propriedade, a duração do contrato de arrendamento, como também as restrições legais. Em seus estudos, estes autores descobriram que a decisão dos clientes por determinada loja é fortemente apoiada na sua conveniência, sobretudo porque os clientes possuem, cada vez, menos tempo, não se permitindo comprar depois de horas extenuantes de trabalho. Assim, eles procuram lojas que lhes ofereçam comodidades, distância de viagem até a loja menor, assim como serviços complementares como o transporte público.

A pesquisa sobre a localização de uma loja tem sido focada na visão do proprietário da loja ou do gestor, buscando maximizar suas receitas. Mais especificamente em relação às lojas de shoppings, a localização é utilizada pelos administradores para maximizar as suas taxas de aluguel dos espaços aos lojistas. A literatura é silente, até onde este autor pôde apurar, quanto à percepção dos clientes sobre se o local onde a loja está situada dentro do shopping é um fator relevante para sua decisão em comprar lá. Em entrevistas-piloto com alguns lojistas e clientes de lojas de shoppings, percebemos alguma evidenciação da importância da localização da loja dentro do shopping para que elas fossem consideradas no conjunto de escolha dos clientes entrevistados. Desta forma, este estudo formula a seguinte hipótese de trabalho:

- H5: o local onde a loja está situada dentro do shopping é uma variável parcialmente determinante para se gerar valor não monetário de loja percebido pelo cliente, sendo relativamente importante para sua fidelização à loja. 
Os resultados serão expostos de acordo com o problema de pesquisa, com os objetivos gerais e específicos, e ainda com as hipóteses de trabalho formuladas. Para melhor entendimento, os resultados e a discussões são baseadas nas respostas dos sujeitos da pesquisa apresentadas na forma de DSC, organizados por questão respondida. Os discursos foram recortados a fim de destacar as ideias centrais (IC) geradas pelos respondentes. Não foi observada nestes discursos a presença de nenhuma ancoragem. A tabela 5 destaca o compartilhamento das Ideias Centrais (IC) obtidas nos depoimentos dos atores sociais entrevistados nesta pesquisa, referentes à pergunta 1 .

Tabela 5: Fonte de fidelidade à loja

1. Mariana compra regularmente e preferencialmente na mesma loja, além de recomendá-la para outras pessoas. Você se vê como a Mariana? Por quê?

\begin{tabular}{|l|l|}
\hline \multicolumn{2}{|c|}{ Ideias Centrais } \\
\hline A & É fiel à loja pela qualidade dos seus produtos. \\
\hline B & É fiel à loja pelo seu nível de atendimento. \\
\hline C & É fiel à loja por sua organização interna. \\
\hline D & É fiel à loja pela afinidade com a marca dos produtos que a loja vende. \\
\hline $\mathbf{E}$ & É fiel à loja pela disponibilidade de mercadoria. \\
\hline
\end{tabular}

Fonte: QualiQuantiSoft® (2015)

\section{DSC 1: razões da fidelidade do sujeito coletivo a certa loja.}

Indagado sobre as razões pelas quais é fiel a uma loja, vemos no discurso do sujeito coletivo que sua satisfação com a qualidade do produto é uma das motivações que lhe faz se sentir seguro para manter um vínculo comercial com a loja e indicá-la para outros clientes. O sujeito coletivo reconhece que o preço é compatível em função da qualidade do produto e de seu caráter de exclusividade.

"Eu gosto muito de comprar na mesma loja porque eu me sinto satisfeito com o produto e, por isto, me sinto seguro para recomendála a outras pessoas. Eu tenho esta preferência por conta da praticidade, 
pois eu já sei que eu vou encontrar um presente de boa qualidade a um valor acessível. É uma loja que me passa confiança, tenho bastante segurança de comprar lá porque ela vende produtos com qualidade. Eu a recomendaria com certeza a outras pessoas, como amigos e parentes, através da propaganda "boca a boca", pois ainda é um recurso quase que infalível. Então, eu adoro os produtos de lá, pois, geralmente, apresentam uma qualidade acima da do mercado. Além disso, eles trabalham com poucas unidades, o que dá um caráter de exclusividade. Por isso, não me incomodo em pagar um pouco mais $(\ldots)$ ".

O sujeito coletivo, ainda em seu discurso, reconhece a importância de um nível de excelência no atendimento para se manter comprando em sua loja. Ele reconhece que buscar uma nova loja é motivo de insegurança em função do receio de não saber se encontrará um atendimento adequado. O sujeito coletivo ainda realça o fato de gostar de se relacionar com os funcionários da loja, de ser reconhecido por seu nome, o que caracteriza a busca por um atendimento personalizado. E ainda mostra que se sente confiante em divulgar as lojas com as quais ele tenha um bom atendimento.

"Eu sempre procuro expressar minha opinião positiva sobre determinada loja, por seu atendimento, para algumas pessoas próximas da minha convivência e em redes sociais onde eu tenha grupos de pessoas conhecidas. Me incomoda bastante, pelo menos, a insegurança, a incerteza de você ir a uma loja e não saber se vai gostar do atendimento. Se eu vou à mesma loja sempre, eu reduzo esse risco de ser mal atendido (...). Eles me dão preferência como cliente, eles me atendem muito bem, por isso eu vou lá, porque eu sei que eles vão me atender bem, vão me tratar super bem. Então eu volto, volto sempre. Eu me fidelizo a algumas lojas por conta do atendimento. Neste caso, eu costumo sempre indicá-la. Eu gosto do fato de me relacionar, de conviver, que as pessoas saibam o meu nome, acho que isso é muito legal, facilita o tempo, eu acho que melhora a qualidade do tratamento. $\mathrm{O}$ respeito com que os funcionários me recebem, desde 
o atendente da loja até o balconista representa um atendimento personalizado que recebo. Eles já conhecem, a fundo, minhas necessidades e isto faz com que eu me beneficie com ganho de tempo".

O sujeito coletivo mostra-se fiel à loja em função, também, de sua organização interna, com as mercadorias bem expostas e, também, por conta da arquitetura moderna das suas instalações, o que caracteriza um ambiente de compra aprazível.

"Eu me vejo como a Mariana: sou fiel, sempre a considero em minhas opções de compra exatamente por causa da organização da loja, por conta das suas instalações modernas. Gosto do ambiente da loja, com as mercadorias bem organizadas por modelo, com funcionários que te dão suporte (...). É muito prazeroso. Eu sempre indico esta loja para amigos e colegas mais próximos quando sou consultado. Eu acho uma loja com uma proposta bem moderna".

Outra razão apontada no discurso do sujeito coletivo para que ele seja fiel à loja é por possuir afinidade com a marca das mercadorias expostas na loja. Ele ressalta que a marca atende aos seus valores e, por isso, tende a indicar as lojas para outros potenciais clientes, sobretudo para pessoas que são neófitas em relação à marca.

"Eu compro alguns produtos na mesma loja já há algum tempo. Sempre que preciso, volto ao shopping para comprar o mesmo produto, então eu tenho uma regularidade de frequência e preferência como a Mariana. Quando eu sinto afinidade com a marca e ela atende os meus valores, eu tendo a recomendá-la sim, eu acho que é bom a gente divulgar aquilo que faz bem e que, enfim, atende as necessidades. Se for uma coisa nova, principalmente, para pessoas que nunca ouviram falar, eu acho que é bacana recomendar sim". 
No final do seu discurso, o sujeito coletivo valoriza a otimização do seu tempo e, por conta disso, sempre busca a mesma loja porque sabe que sempre vai encontrar lá o que procura. A praticidade na busca por produtos é o que o fascina. No final, ele ressalta a importância de sempre ter a mercadoria que procura a um preço que lhe é acessível.

"Sim, eu me vejo (fiel à loja). Por exemplo... eu gosto de ir sempre a uma certa loja, porque sempre eu acho as mesmas coisas que eu procuro. Então, eu não fico procurando em outro lugar, eu já sei que tem ali. Eu a recomendo para outras pessoas. Olha, pensando em uma situação, por exemplo, de quando eu estou comprando um presente para alguém, tendo de ir a uma festa de aniversário, eu quero uma praticidade, eu quero ir a um lugar onde eu já sei que eu vou encontrar uma coisa, um presente, a um valor acessível. Então, já procuro a mesma loja sempre".

A tabela 6 destaca o compartilhamento das Ideias Centrais (IC) obtidas nos depoimentos dos atores sociais entrevistados nesta pesquisa, referentes à pergunta 2.

Tabela 6: A música ambiente como forma de agregar valor para o cliente.

2. Em sua opinião, a música ambiente da loja é um benefício para o cliente?

\section{Ideias Centrais}

\begin{tabular}{|l|l|}
\hline A & A música ambiente agrega valor pelo posicionamento da loja. \\
\hline B & A música ambiente agrega valor por tornar o ambiente de loja aprazível. \\
\hline C & A música ambiente não agrega valor quando não é bem conceitualmente pensada em termos de \\
& volume, trilha musical etc.)
\end{tabular}

Fonte: QualiQuantiSoft® (2015) 


\section{DSC2: a música ambiente como potencial fonte geradora de valor.}

Em seu discurso, o sujeito coletivo entende que ela é um atributo importante de compra, pois consegue mostrar aos frequentadores da loja qual o perfil dos clientes que ela deseja atender. O sujeito coletivo afirma ainda que a música ambiente deve, de fato, estar alinhada ao seu público-alvo a fim de se evitar erros de posicionamento, por parte da loja, que comprometam a experiência de compra dos compradores.

"Sim, eu gosto de ouvir música ambiente, acho legal. Dá até para entender um pouco melhor o estilo da loja, se ela é mais jovem, se ela tem outro tipo de público. Dependendo da loja e do produto (a quem se destina), nem sempre há a necessidade de música ambiente, mas quando combina pode ser bem interessante! Por isto, eu concordo que a música ambiente agrega valor quando está alinhado ao público, adequada ao perfil do consumidor. Por exemplo, um jovem, quando entra em uma loja, ele tem música para jovem. Então a loja deve adotar a música ambiente com adequação. Acredito que a música ambiente tem de ter essa capacidade de interagir com os clientes, ou seja, é fundamental que ela seja voltada para o seu público-alvo, senão fica um desajuste para ambos".

O sujeito coletivo afirma, também, que a música exerce um papel preponderante em sua experiência de compra ao tornar a loja um ambiente agradável acolhedor. Ele ressalta a importância da música ambiente em atuar como um dissipador de barulhos, como as conversas entre clientes e vendedores ou mesmo entre os próprios clientes. Mais, diz que música ambiente é até um convite para ele permanecer mais tempo na loja, vendo mais opções de mercadorias.

"Eu acho que deixa o ambiente mais agradável, ainda mais se for um estilo de música que eu gosto. Essa loja onde eu costumo ir tem um ambiente que me agrada, ela tem uma música que me agrada, então eu costumo ir lá porque o ambiente é bacana para mim. Isso para mim é 
um benefício. A música é um fator tranquilizador, e quando a gente entra em uma loja com um ambiente agradável, com um ambiente tranquilo, com uma música de fundo agradável, dá um bem-estar na pessoa e o cliente se sente mais à vontade, não se sente pressionado para fazer a compra. O cliente sente um ambiente que lhe faz bem, daí ele fica mais à vontade para comprar, sente aquele ambiente prazeroso. Por isso, eu a acho muito importante e a considero um benefício para o cliente por tornar o ambiente da loja agradável, mais atrativo. Eu acho que a música ambiental faz com que as pessoas relaxem, até comprem mais, tendo em vista que ela faz a loja parecer mais aprazível. Além disto, ela permite que os outros sons dentro da loja, como as conversas entre clientes, possam ser um pouco dissipados, auxiliando a manter um clima mais harmonioso dentro da loja. Eu sempre relaxo com a música ambiente... me faz querer permanecer mais tempo, pesquisando as mercadorias. Acredito que uma loja sem música ambiente se torna enfadonha, sem graça (...)”.

Ainda em seu discurso, o sujeito coletivo salienta que, no entanto, quando a música tocada na loja é em volume muito alto ou quando são executadas músicas de estilos não compatíveis com o perfil dos frequentadores, ela deixa de ser um benefício.

"Se for uma música ambiente mesmo, aquela música tranquila, com certeza. O que me incomoda, às vezes, é as lojas com músicas com som muito altos. Por outro lado, se a música ambiente é agradável, pode ser que ela seja capaz de reter o cliente na loja. Eu odeio as lojas com aquelas caixas de som na porta, nem entro. Eu olho as vitrines, e posso até gostar, mas já nem entro, porque é muito barulho. A música ambiente pode me afastar ou me acolher: se for uma música que agrade os meus ouvidos, então, sim, ela pode me acolher, ela pode me fazer ficar mais tempo inclusive na loja. Mas se for uma música de um estilo que eu não gosto, ela vai me afastar com certeza. Resumindo, então, se for uma música agradável aos ouvidos, acredito que seja uma boa ideia sim. No entanto, se a música for ruim, atrapalha muito o ato 
da compra. Aliás, penso até que uma música ambiente ruim é capaz de expulsar o potencial cliente".

A tabela 7 destaca o compartilhamento das Ideias Centrais (IC) obtidas nos depoimentos dos atores sociais entrevistados nesta pesquisa, referentes à pergunta 3.

Tabela 7: a música ambiente como forma de agregar valor para o cliente.

\begin{tabular}{|l|l|}
\hline 3. & Em sua opinião, a iluminação dentro da loja é um benefício para o cliente? \\
\hline A & A iluminação agrega valor por destacar os produtos da loja. \\
\hline B & A iluminação agrega valor por destacar o ambiente de loja. \\
\hline C & $\begin{array}{l}\text { A iluminação não agrega valor quando não é bem conceitualmente pensada em termos de } \\
\text { intensidade, por exemplo. }\end{array}$ \\
\hline
\end{tabular}

Fonte: QualiQuantiSoft@ (2015)

DSC3: A iluminação como potencial fonte geradora de valor.

O sujeito coletivo realça a importância da iluminação para poder interagir melhor com os produtos expostos na loja. Ele chama a atenção para o fato de que uma boa iluminação permite-lhe ver melhor as características físicas das mercadorias, podendo detectar, até mesmo, algum defeito aparente. Além disso, ele destaca a importância de uma boa iluminação para destacar as mercadorias, chamando a atenção dos compradores para aqueles produtos específicos. Ele ressalta ainda que uma iluminação ruim pode gerar uma certa desconfiança nos clientes, até mesmo, em relação à qualidade das mercadorias da loja.

"Quando eu entro em uma loja, eu quero visualizar bem o produto que desejo comprar, de repente, até mesmo para enxergar algum defeito. Se a loja está bem iluminada, a gente consegue ver melhor o produto em detalhes (...) até mesmo alguma coisa que pode não agradar depois. Eu gosto de lugar bem iluminado porque você pode focar mais em alguns tipos de produto em detrimento de outros. Eu penso que se o lojista pretende destacar algum produto específico, a iluminação faz 
todo sentido. Por isto, eu acho que é um benefício não apenas para o cliente mas para loja também. Quando o cliente vê uma iluminação diferenciada, algo que chame sua atenção, ele vai observar o produto com mais naturalidade, ver melhor sua qualidade e fazer uma escolha certa. Por exemplo, eu já estive em lojas onde os produtos eram bonitos, mas você não conseguia enxergá-los direito, ou porque a loja estava com pouca luz ou porque a luz estava piscando. Eu acredito que a iluminação certa faz o cliente ver o produto com melhor clareza, despertando seu interesse em comprar aquela mercadoria que está em destaque. Do contrário, quando a loja deixa tudo muito escuro, isso é um desserviço, porque além de não mostrar a mercadoria, pode causar uma certa desconfiança por parte do consumidor em relação à qualidade de produção da peça. Enfim, a iluminação, quando bem concebida, permite harmonizar a loja, tornando-a funcional, ou seja, valorizando as mercadorias, destacando os lançamentos, dando ênfase ao produto etc.".

Ainda em seu discurso, o sujeito coletivo atribui uma importância à iluminação interna da loja ao afirmar que ela propicia um ambiente mais agradável, traduzido em conforto, durante sua permanência neste local. Afirma também que a iluminação propicia um aspecto de loja mais "clean", arrumada, acolhedora, permitindo uma fácil locomoção em seu interior, tornando sua experiência de compra mais satisfatória. No final, o sujeito coletivo reconhece que a iluminação realça a arquitetura interna da loja e acrescenta que lojas escuras não permitem uma fácil localização das mercadorias expostas.

"Uma boa iluminação no ambiente... faz a diferença. Uma má iluminação não deixa o ambiente acessível, a iluminação é tudo no lugar. A iluminação me representa clareza, limpeza, asseio com as coisas, o cuidado também com o cliente. Eu vejo que é uma das coisas que mais torna o ambiente agradável para estada do cliente na loja porque além de ele ficar mais à vontade, a iluminação traz até um conforto, fazendo com que o cliente queira ficar mais tempo dentro da 
loja. Se a gente for pensar em valor percebido, eu acho que já é uma coisa intrínseca, é algo que tem que fazer parte, são coisas básicas já de um serviço na nossa economia atual. A iluminação permite que a loja possa ser apreciada em sua essência, em sua plenitude. Ela torna o ambiente de loja mais acolhedor. Ela é fundamental para tornar o ambiente interno da loja acessível, fácil de entrar e sair da mesma, sem esbarrar nas mercadorias e/ou nas pessoas. Por isto, eu a reputo como uma das principais características que uma loja deva conceber em sua arquitetura interna. A iluminação facilita, enormemente, o tráfego dentro da loja, guiando o consumidor em seu interior. E além do mais, a iluminação evita aquela preguiça, aquela leniência de comprar. A iluminação, a meu ver, exerce um papel crucial, sim, na ambientação da loja, porque ela ajuda a valorizar o ambiente interno da loja, realçando o design, a arquitetura da loja. Eu penso sempre como é ruim para o cliente aquelas lojas escuras, que mais parecem pardieiros, onde você não encontra nada ali dentro".

Porém, o sujeito coletivo, em seu discurso, chama a atenção para a utilização, com bom senso, da iluminação no interior da loja, de maneira a atender, na medida do possível, ao gosto da maior parte de seus frequentadores, sem escassez ou excessos. Segundo ele, nestas condições, a iluminação deixa de ser um benefício.

"No caso da iluminação, eu penso que algumas lojas que são muito escuras, muito aconchegantes demais, podem dar sono e não vontade de adquirir. E há outras que tem um excesso de iluminação, o que também é ruim. Então, a iluminação adequada seria uma intermediária, nem muito forte e nem muito fraca. Por exemplo: em algumas lojas, a iluminação é intensa, gerando um pouco de incômodo nos olhos dos clientes, fazendo com que eles não comprem a mercadoria. Mas, por outro lado, se a loja tiver um ambiente muito escuro, pode não ficar muito agradável para o cliente realizar suas compras. Isso tem que ser bem pensado pelo gestor da loja. 
Finalizando, a iluminação, quando bem concebida, permite harmonizar a loja”.

A tabela 8 destaca o compartilhamento das Ideias Centrais (IC) obtidas nos depoimentos dos atores sociais entrevistados nesta pesquisa, referentes à pergunta 4.

Tabela 8: o layout como forma de agregar valor para o cliente.

4. O layout de loja diz respeito à forma como os produtos, gôndolas e corredores são organizados. Também inclui a concepção do espaço e a alocação, o agrupamento e a colocação da mercadoria. Você acredita que o layout da loja é um benefício para seus clientes? Por quê?

Ideias Centrais

A $\quad$ O layout agrega valor pela comodidade da localização do produto.

B O layout agrega valor por favorecer a organização da loja.

Fonte: QualiQuantiSoft® (2015)

O exame do discurso do sujeito coletivo, abaixo, nos permite afirmar que o mesmo entende que o layout da loja é fundamental para que os clientes possam encontrar facilmente as mercadorias que procuram. Quando, segundo ele, as mercadorias estão organizadas por modelo, cor e tamanho, o cliente economiza tempo, recurso primordial no mundo contemporâneo. Critica ainda quando as lojas varejistas mudam constantemente seus layouts, dificultando a localização das mercadorias que deseja por estas não estarem mais no local onde anteriormente se encontravam. No final, ele ressalta a importância do layout para a comodidade dos clientes no que se refere, sobretudo, ao tempo de permanência destes na loja.

"A disposição dos produtos facilita a identificação da mercadoria pela qual eu tenho preferência. Isto já me direciona para aquilo que eu quero e eu ganho mais tempo. Então acho que isso contribui bastante para facilitar a compra. Quando a loja organiza as mercadorias por numeração e modelo facilita a sua localização, reduzindo o tempo de procura do cliente por essas mercadorias e otimizando o seu tempo da escolha. Se a loja tem uma boa arrumação dos produtos, eu já sei que eu vou chegar lá, vou ao corredor tal, à sessão tal, escolho o que eu 
quero e vou para o balcão. A arrumação das mercadorias também é importante quando, por exemplo, o cliente chega à loja e começa a olhar as mercadorias para ver se se interessa por alguma. Se ele já sabe onde estão as mercadorias, isto ajuda na regularidade de suas compras porque ele já vai lá sabendo onde está o que ele quer. Então, eu creio que o principal benefício da arrumação das mercadorias é a facilidade de o cliente procurar tal modelo, principalmente quando está com pressa. Ele vai, por exemplo, direto na numeração, não precisa ficar procurando e tentando achar o seu tamanho. Eu vejo que, sobretudo, no varejo, de tempo em tempo, as lojas mudam toda a disposição dos seus produtos (...). Isto é um inferno. O tempo que se perde para você redescobrir onde estão as coisas, encontrar os produtos que você quer é um problema. Então, qualquer ação que economiza tempo hoje em dia eu diria que é um benefício sim. Por isto, a arrumação das mercadorias é um benefício porque o cliente ganha tempo quando encontra as mercadorias expostas por tamanho, cor e modelo. Eu fico realmente fascinado quando vejo os vendedores da loja sempre atentos para reorganizar as peças de roupas que foram bagunçadas pelos clientes. Afinal, isto é inevitável, o cliente vai sempre querer tocar e experimentar o produto antes de comprá-lo. Então, para concluir, eu acredito que esta questão seja muito relevante hoje em dia, pois vivemos em um mundo corrido onde as coisas estão cada vez mais dinâmicas e o nosso tempo não acompanha este ritmo. Então, se a loja te facilita com a exposição da mercadoria, sem dúvida que isto vai facilitar sua vida".

Ainda em seu discurso, o sujeito coletivo ressalta a importância do layout como símbolo de respeito da loja para com os seus frequentadores, o que se traduz em confiança por parte destes. Afirma que os clientes não se sentem motivados a entrarem em lojas desarrumadas por transmitirem uma sensação de poluição visual, quando, por exemplo, as gôndolas estão muito próximas, dificultando o livre deslocamento dentro da loja. 
"Eu acredito que a organização dentro de uma loja, como toda empresa, é um fator preponderante para gente escolher aquela loja para comprar, pois demonstra o respeito com o cliente. Para mim, ver a coisa muito organizada é sinal de que eu posso confiar naquela loja. Se eu vejo que está tudo desorganizado eu não tenho nem motivação para entrar nessa loja, eu sei que eu vou ser mal atendida, eu sei que os vendedores não são qualificados, essa é uma suspeita que eu tenho, já nem me motiva a entrar nessa loja. Eu costumo dizer que uma loja sem uma arrumação adequada vira uma poluição visual que afasta os clientes, pois ninguém quer entrar em uma loja que mais parece um labirinto como, por exemplo, quando as gôndolas estão próximas umas às outras. É horrível! Os corredores de uma loja devem, realmente, ser amplos de maneira a facilitar o livre fluxo de clientes dentro da loja. Portanto, acredito que a disposição de todos estes itens é fundamental para uma boa experiência de compra em determinada loja".

A tabela 9 destaca o compartilhamento das Ideias Centrais (IC) obtidas nos depoimentos dos atores sociais entrevistados nesta pesquisa, referentes à pergunta 5.

Tabela 9: a disponibilidade de mercadoria como forma de agregar valor para o cliente.

5. Paulo afirma que gosta de comprar na loja $X Y Z$ porque encontra regularmente as mercadorias que procura. Você acha que a disponibilidade de mercadoria é um benefício para o cliente? Por quê?

\section{Ideias centrais}

A A disponibilidade de mercadorias agrega valor para o cliente pela comodidade da economia de tempo.

B A disponibilidade de mercadorias agrega valor para o cliente pela comodidade da economia dos outros custos de pesquisa.

Fonte: QualiQuantiSoft® (2015) 
O sujeito coletivo diz que ter a certeza de que encontrará sempre a mercadoria que procura em uma loja é um fator essencial para ele voltar a escolhê-la. Frisa que a disponibilidade de mercadoria é um diferencial por lhe gerar economia de tempo, pois não vai precisar procurá-la em lojas concorrentes. Diz ainda que se ele percebe certa dificuldade em encontrar a mercadoria na loja (stockout), a tendência é que deixe de frequentá-la.

"Se eu chegar a uma loja e não tiver o produto que eu quero, eu perdi meu tempo. Então, eu quero chegar lá e ter a certeza que tem a mercadoria lá. Penso que um dos critérios para o cliente, com certeza, escolher uma loja é a diversidade do estoque, pois ele sabe que a loja vai ter aquilo que ele quer. Isso economiza o seu tempo, lhe dá mais tranquilidade. Se a loja tem o que o cliente deseja, está atendendo às suas necessidades, então, não há por que trocá-la, pois ele estará economizando tempo não tendo de ir em outro lugar. A loja ter o produto que você procura é essencial porque você não vai perder tempo de procurar, de pesquisar. É péssimo, se você começa a ter dificuldade para encontrar o produto que quer (uma hora tem, uma hora não tem). É importante a disponibilidade da mercadoria para o cliente para que ele não perca muito tempo na busca de modelos, cores e tamanho. Ao fazer compras, eu quero chegar, entrar naquela loja e encontrar o que procuro. Como o nosso dia a dia é mais corrido, eu ganho tempo, porque eu sei que eu não vou precisar ficar procurando em várias lojas. Então, para concluir, a disponibilidade de mercadorias na loja é uma vantagem para o cliente, certamente, porque você evita a perda de tempo.

O sujeito coletivo, ainda em seu discurso, vê a disponibilidade de mercadorias como uma vantagem porque ele passa a ter redução de outros custos associados à busca pela mercadoria, não somente financeiros (pagamento com estacionamentos, combustível e estacionamento), mas psicológicos (estresse ao se buscar estacionamento, de engarrafamento no trânsito etc.). No final, o sujeito coletivo reconhece que com a disponibilidade de mercadoria, possivelmente, ele terá, também, uma maior diversidade de opções. 
"Ela é uma vantagem para o cliente porque evita uma elevada despesa financeira com estacionamento, o desgaste emocional para achar a vaga. Então, eu a vejo como um benefício. É isso que eu busco na loja, eu quero ir lá e encontrar a mercadoria que eu estou procurando para não ficar peregrinando de loja em loja. Ir a uma loja com a certeza de encontrar o produto é fundamental, sobretudo em cidades caóticas como São Paulo. A diversidade e a disponibilidade de mercadorias me fazem ter a certeza de que obterei vantagens com a redução do tempo de deslocamento e com os custos da procura. Quando se vai a uma loja e não se encontra o que se está buscando é uma experiência traumática, pois você tem um gasto exorbitante com combustível, estacionamento, alimentação etc. A disponibilidade de mercadoria sempre será um excelente benefício para qualquer cliente, pois a vida atribulada que temos, atualmente, é realmente muito complicado pensarmos nos deslocamentos dentro das grandes metrópoles. Além da economia de tempo, refiro-me, aqui, aos benefícios financeiros e psicológicos, como a redução do estresse, enfim. Cabe destacar, também, que a disponibilidade de mercadoria na loja já serve como um diferencial para mim em comparação às outras lojas, pois sei que terei diversidade de modelos e, com isto, minha pesquisa será proveitosa".

A tabela 10 destaca o compartilhamento das Ideias Centrais (IC) obtidas nos depoimentos dos atores sociais entrevistados nesta pesquisa, referentes à pergunta 6.

Tabela 10: a presença dos vendedores como forma de agregar valor para os clientes

6. Você acredita que a presença dos vendedores na loja é um fator relevante para sua decisão em comprar lá?

\section{Ideia Centrais}

A $\quad$ Os vendedores, quando bem treinados, agregam valor ao cliente por seus conhecimentos técnicos.

B Os vendedores, quando bem treinados, agregam valor ao cliente por seu nível de atendimento.

C Os vendedores não agregam valor quando colocam seus interesses pessoais em primeiro plano em detrimento dos do cliente.

Fonte: QualiQuantiSoft® (2015) 


\section{DSC 6: os vendedores como potencial fonte geradora de valor.}

O sujeito coletivo, em seu discurso, atribui grande importância aos vendedores em sua experiência de compra. Segundo ele, estes, por seus conhecimentos técnicos, podem auxiliar os clientes em suas escolhas, dirimindo as suas dúvidas quanto à melhor mercadoria para atender às suas necessidades, sobretudo quando se tratam de produtos mais diferenciados. $\mathrm{O}$ sujeito coletivo também chama a atenção para as situações em que ele precisa comprar um presente para alguém e o vendedor, por sua experiência, é capaz de lhe apontar a melhor alternativa.

"Os vendedores são peças fundamentais nos estabelecimentos comerciais. Por meio de vendedores bem treinados, as lojas visam propiciar um bom atendimento e uma maior versatilidade para o cliente quando, por exemplo, eles buscam as mercadorias ou prestam informações sobre as mesmas. Quando vou a uma loja, eu procuro um vendedor, pois eu sei que ele vai me auxiliar pelo seu conhecimento técnico, pela sua experiência. Às vezes, eu posso ter a intenção de comprar um produto e ele, pelo seu conhecimento, pode me oferecer um produto melhor. Se você tiver um vendedor que te inspira confiança, você fica mais tranquilo, já reduz a sua insegurança, sobretudo, quando se trata da compra de produto menos “comoditizado". Às vezes, você vai comprar uma peça que não é para si, é um presente, por exemplo. Neste caso, saber que pode contar com a assessoria do vendedor é um benefício para mim porque saio da loja com um pouco mais de segurança no produto que comprei. $\mathrm{Na}$ verdade, o vendedor acaba auxiliando na nossa escolha, em caso de dúvida. O atendimento dos vendedores é extremamente importante, principalmente, quando compro produtos mais diferenciados, como eletroeletrônicos. O conhecimento técnico do vendedor auxilia enormemente nesta questão. Então, eu acredito que os vendedores sejam peças importantes nesta engrenagem dos serviços, pois eles podem auxiliar os compradores na aquisição dos produtos, pois 
conhecem a fundo as características técnicas de determinadas mercadorias, sobretudo quando são diferenciadas. Considero essencial o vendedor na loja para poder te auxiliar na escolha da melhor opção de produto".

No discurso do sujeito coletivo, fica ainda evidenciado a importância dos vendedores para os clientes por conta da qualidade do atendimento. Neste caso, isto se traduz na disponibilidade do vendedor em lhe mostrar a loja, em lhe oferecer mais opções de mercadorias (modelos, tamanhos, cores), em lhe receber amistosamente, em lhe apresentar os planos de pagamento etc. Neste caso, o sujeito coletivo afirma que tende a voltar à loja para comprar as mercadorias, ainda que estas sejam mais caras. Ele termina seu discurso, afirmando que o atendimento dos vendedores acaba sendo o grande divisor de águas entre as lojas, ainda segundo ele, cada vez mais padronizadas entre si.

"Quando eu vou em uma loja onde o atendente tem mais disposição para trazer outros modelos do produto que desejo ou mesmo semelhantes, eu acho que é legal porque se eu não gostei de um eu vou gostar de outro e, assim, eu me sinto bem atendido e acolhido. E um bom atendimento resulta, com certeza, no meu retorno à loja. $\mathrm{O}$ atendimento do vendedor também influencia na minha decisão, na minha escolha, porque se eu vou a uma loja e não sou bem atendido, é quase impossível que eu volte. $\mathrm{O}$ acolhimento que os vendedores das lojas dão aos seus clientes faz com que estes se sintam valorizados, queridos, acolhidos, e isso é um incentivo para que ele compre naquela loja, volte àquela loja, continue comprando os seus produtos sempre porque sabe que vai ter um bom atendimento, que vai ter alguém preparado para atendê-lo e que gosta do que faz. Isso é bom para quem está comprando. Acho que o atendimento é primordial. Quando os vendedores são bem treinados, você volta à loja, mesmo que o produto seja mais caro, até em função de ter sido bem atendido pelo vendedor. Eu penso que, mercadoria por mercadoria, todos os estabelecimentos vão ter. O que para mim é um grande diferencial em 
uma loja, com certeza, é o atendimento de um bom vendedor: ele te apresentar a loja, te apresentar os produtos, te apresentar os planos, mostrar os modelos, os tamanhos, cores etc. Com toda certeza, creio que o atendimento é um benefício e é neste ponto que as lojas mais conseguem se diferenciar hoje em dia. Basicamente, os produtos parecem cada vez mais padronizados e a loja vai se diferenciando, realmente, na delicadeza, na gentileza, nos detalhes da prestação de serviço. Olha, acho que dos itens que a gente falou até agora, o atendimento é o mais importante".

Por outro lado, o sujeito coletivo transmite uma preocupação com o papel real a ser desenvolvido pelos vendedores na solução dos problemas dos clientes, ou seja, eles não devem priorizar seus interesses pessoais por premiação ou comissão em detrimento dos reais interesses dos seus clientes. Evidente que, ao proceder desta forma, a presença do vendedor deixa de ser uma fonte de benefícios aos olhos do sujeito coletivo.

"Ser bem atendido, claro, é um diferencial, um acolhimento. No entanto, o que vejo, algumas vezes, é o vendedor usar das suas técnicas de vendas para tentar empurrar outros produtos. Eles estão mais preocupados com suas comissões do que com as necessidades reais de seus clientes. Por outro lado, ainda existem aqueles vendedores com os quais você já passa a ter uma relação de amizade, de companheirismo, pois você sabe que ele está buscando realmente satisfazer seus anseios". 
A tabela 11 destaca o compartilhamento das Ideias Centrais (IC) obtidas nos depoimentos dos atores sociais entrevistados nesta pesquisa, referentes à pergunta 7.

Tabela 11: a imagem da loja como forma de agregar valor para o cliente.

7. A imagem corporativa está relacionada à impressão que os clientes têm sobre a qualidade das mercadorias e do nível dos serviços da loja (assistência técnica, garantia oferecida, política de trocas etc.). Você acredita que a imagem exerce alguma influência sobre a decisão de compra destes clientes?

\section{Ideias Centrais.}

A A imagem corporativa da loja agrega valor por transmitir confiabilidade, segurança.

B A imagem corporativa da loja não é sinônimo de benefício para alguns clientes.

Fonte: QualiQuantiSoft® (2015)

\section{DSC 7: a imagem da loja como potencial fonte geradora de valor.}

No discurso do sujeito coletivo, percebemos a importância que ele atribui à imagem corporativa da loja, referendando o fato de ela possuir produtos de boa qualidade e uma política eficiente de pós-venda (assistência técnica, política de trocas etc.). Segundo ele, a imagem de credibilidade que a loja passa aos seus clientes, por meio de sua política pós-venda e da excelente qualidade de suas mercadorias, é um fator preponderante para que ele se mantenha vinculado a ela.

"Eu acho que o fato da empresa ter uma mercadoria de boa qualidade, uma boa apresentação técnica dos seus produtos retrata uma imagem positiva que ela tem no mercado. Esta imagem de confiabilidade que a loja me passa é fundamental, pois terei a certeza de que estou adquirindo produtos com qualidade. Ao apresentar boas mercadorias, o lojista passa a imagem de credibilidade aos seus clientes". A imagem de uma loja com confiabilidade reduz as incertezas não só em relação à qualidade do produto que ela esteja oferecendo, mas também em relação aos custos adicionais de reparo que os clientes possam incorrer no caso da mercadoria vir a ser danificada. A credibilidade da 
imagem da loja passa confiança: você sabe que se comprar nessa loja vai ter um serviço pós-venda no caso de algum defeito do produto. Sabe que se tiver algum problema, ele será resolvido de forma rápida, com uma troca, talvez. O serviço pós-venda com certeza distingue o lojista porque o cliente fica mais bem informado sobre a utilização do produto, sobre como solicitar reparo em caso de defeito do produto. Se o lojista tem um serviço de pós-venda estruturado, qualificado, passa segurança aos seus clientes, fazendo com que eles avalizem a loja. Para mim, mais importante do que a compra em si é o pós-venda, pois se aparecer algum problema com a mercadoria, eu quero ser tão bem atendido na minha reclamação quanto quando eu fui comprar. Se isto ocorrer, com certeza, você vai fidelizar essa loja para o resto da vida. Então, posso lhe garantir que a imagem de credibilidade de uma loja é um fator primordial para eu manter vínculo com ela".

O sujeito coletivo, entretanto, em seu discurso, reconhece que nem todos os clientes reconhecem que uma boa imagem corporativa possa ser um atributo igualmente valorizado pelas pessoas. Acredita, desta forma, que a imagem pode servir como um endosso para se indicar uma loja a alguém, mas não acredita que isto seja um diferencial para que esta pessoa decida pela loja indicada.

“A confiabilidade na imagem de uma loja é muito subjetiva. Eu acho que a indicação, o endosso que um cliente dá sobre a loja pode ser um fator de credibilidade para alguns consumidores, mas, por conta disto, ser visto como um benefício igualmente por todos, eu não concordo, porque o que ele enxerga como sendo valor percebido, o que ele entende de vantagem para ele, talvez não seja para outros consumidores. Talvez, alguns clientes valorizem atributos que para outros são irrelevantes. Por exemplo, um lojista pode executar muito bem algum serviço que eu não valorize tanto, enquanto, por outro lado, pode negligenciar outro que para mim é essencial. Mas pode ser que outro cliente pense contrariamente a mim, acreditando que todos os serviços sejam essenciais. Então, eu diria que a confiabilidade que 
um cliente tem na imagem da loja pode não ser visto igualmente como um benefício por todos.

A tabela 12 destaca o compartilhamento das Ideias Centrais (IC) obtidas nos depoimentos dos atores sociais entrevistados nesta pesquisa, referentes à pergunta 8.

Tabela 12: o prestígio da loja como forma de agregar valor para o cliente

8. Renato afirma que a loja $\mathrm{ABC}$ possui certo prestígio em função de seu tempo de existência no mercado. Você acredita que este prestígio é um elemento importante para se comprar nesta loja? Por quê?

Ideias Centrais.

\begin{tabular}{|l|l|}
\hline A & $\begin{array}{l}\text { O prestígio da loja agrega valor para o cliente, sendo um elemento importante para a sua decisão de } \\
\text { compra. }\end{array}$ \\
\hline B & $\begin{array}{l}\text { O prestígio da loja não é um atributo relevante para a decisão do cliente de comprar em determinada } \\
\text { loja. }\end{array}$
\end{tabular}

Fonte: QualiQuantiSoft@ (2015)

\section{DSC 8: o prestígio da loja como potencial fonte geradora de valor.}

O sujeito coletivo, inicialmente, afirma que se uma empresa está há tanto no mercado, ela goza de prestígio porque, teoricamente, é uma empresa que apresenta bons produtos e um bom nível de atendimento. Ele também afirma que uma empresa com prestígio lhe transmite confiabilidade, segurança e até mesmo lhe influencia em sua decisão de comprar nesta loja.

"Sim, porque a tradição acaba sendo uma referência, é uma loja que já tem nome e isso, querendo ou não, passa mais credibilidade. Acho que se ela está há tanto tempo no mercado é porque consegue solucionar o problema do cliente, dar um bom atendimento, ter um pós-venda. $\mathrm{O}$ prestígio da loja reduz os riscos, pois se ela é tradicional, tem muito tempo, tem muito cliente, provavelmente venda um bom produto, tenha uma boa assistência técnica, tenha capilaridade. A tradição de 
mercado traz prestígio, traz confiança. Eu penso que é um elemento decisivo também para se comprar em determinada loja. A tradição da loja significa que ela conseguiu cumprir com sua visão de mercado, soube apresentar seus diferenciais para os seus clientes. Se a loja mostra toda a seriedade e honestidade com que trabalha, o cliente vai voltar lá. Então o cliente tem que sentir que realmente ele está trabalhando com uma loja que o respeita. Isto é tradição. Eu acho que se uma loja é tradicional no mercado é porque oferece bons serviços. A tradição da loja é importante porque mostra que ela atende bem seus clientes. Uma loja com prestígio no mercado é motivo para eu comprar lá e indicá-la para outras pessoas porque você sente confiança, segurança e prazer em comprar ali. O prestígio, que se constrói ao longo do tempo, resulta em uma consolidação de fidelidade do cliente para com a loja. Se loja já tem um nome conhecido, uma marca reconhecida, já está há tanto tempo no mercado, é porque os produtos são de qualidade, então vai trazer credibilidade, consequentemente eu vou continuar comprando lá. O prestígio da loja associado à sua tradição de mercado é uma das fontes de sua credibilidade no que se refere à sua prestação de serviços. $\mathrm{O}$ prestígio de uma loja por sua história me faz usar isso a favor da empresa em minha avaliação. O prestígio realmente influencia a decisão do cliente em comprar em determinada loja, pois isto the sinaliza que é uma empresa conceituada no mercado. Inclusive, existem muitas lojas que utilizam a mensagem "since", referindo-se ao seu lançamento, para reforçar seu pioneirismo no mercado".

Por outro lado, o sujeito coletivo também afirma que nem todos os clientes veem o prestígio de loja decorrente da sua tradição no mercado como critério para sua decisão de compra. Ele afirma que mesmo as lojas sem muita tradição no mercado podem possuir produtos superiores e melhor atendimento do que aquelas com maior tempo de existência, com relativo prestígio. As indicações, ainda segundo ele, também exercem uma influência na escolha de alguns clientes por determinada loja. 
"No entanto, eu reconheço que isto (a tradição de mercado) nem sempre é relevante para todos os clientes na sua decisão de escolha por determinada loja. Acredito que outras pessoas sejam mais suscetíveis às indicações de amigos, colegas. Embora, eu acredite que o prestígio de uma loja, decorrente de sua tradição de mercado, seja importante, vejo que, hoje em dia, o elemento decisivo para algumas pessoas é a qualidade, tanto das mercadorias quanto do atendimento. Não adianta ter prestígio se a mercadoria, com o tempo, se tornou inferior (...). Podem ser lojas com prestígio (...), mas se pisam na bola uma vez, duas, se não tem o atendimento legal, acho que acaba deteriorando a próprio marca, um tiro no pé. Às vezes, em uma loja não tão conhecida, pode se ter também um bom atendimento e uma boa arrumação (...). Eu mesmo conheço casos de lojas recém-lançadas no mercado e que demonstram preocupação com seus clientes ao lhes oferecer um atendimento diferenciado (...).

A tabela 13 destaca o compartilhamento das Ideias Centrais (IC) obtidas nos depoimentos dos atores sociais entrevistados nesta pesquisa, referentes à pergunta 9.

Tabela 13: o local onde a loja está situada dentro do shopping como forma de agregar valor para o cliente.

9. O local dentro do shopping center onde a loja está situada tem alguma influência sobre sua decisão em comprar em determinada loja?

\section{Ideias Centrais}

A $\quad$ O local onde a loja está situada no shopping agrega valor para o cliente, influenciando-o em sua decisão de compra.

B O local onde a loja está situada no shopping não é um critério relevante para a decisão do cliente de comprar em determinada loja.

Fonte: QualiQuantiSoft® (2015) 
DSC 9: O local onde a loja está situada no shopping como potencial fonte geradora de valor.

O sujeito coletivo foi convidado a responder sobre se o local onde a loja estava situada no shopping exercia ou não alguma influência em sua decisão de compra. Como na questão anterior, ele afirma que este local é um benefício importante e que ele leva em consideração para escolha da loja onde pretende comprar. Estimulado a responder sobre que locais seriam esses, o sujeito coletivo afirmou que o local deve ser de fácil acesso. Assim, ele elencou possíveis locais onde a loja poderia se situar no shopping: nos corredores mais amplos, próxima de lojas âncoras, de entradas e saídas e de estacionamentos. Desta forma, acredita ele, os clientes teriam maior comodidade, usufruindo, sobretudo, de economia de tempo, porque estes locais facilitam a experiência de compra nas lojas dentro dos shoppings.

"Não tenho dúvida que a localização da loja é importantíssima, pois se ela é de fácil acesso, torna-se convidativa. O cliente acaba entrando na loja e comprando alguma coisa. Se a loja está localizada em um ponto mais acessível, facilita. Do contrário, se ela está muito escondida, torna-se mais complicado chegar lá (...). Em relação aos pontos de localização, os mais interessantes são os de maior circulação e mais perto da entrada e saída do shopping. Uma boa localização para uma loja seria perto de âncoras (lojas), porque a gente acaba tendo aquele hábito de frequentá-las pela segurança em comprar ali. Eu gosto da praticidade. Portanto, geralmente eu opto por lojas situadas próximas às entradas e saídas, pois facilita a minha vida. Eu resolvo o que é preciso na loja e vou embora. Também gosto de lojas próximas ao estacionamento pela comodidade de já sair do carro e já me dirigir para ela. O local onde a loja está presente com certeza é muito importante para se efetuar a compra, pois geralmente os shoppings têm andares longos, grandes e com certa dificuldade de acesso a determinadas lojas. Bom, eu sou o típico consumidor que gosta daquilo que é mais fácil. Então, por exemplo, as lojas que eu frequento, normalmente, estão bem próximas à entrada. Então, já sei 
que naquele primeiro corredor, em tal lugar, está a loja. Já vou direto lá, compro e saio. É uma vantagem, para mim, é interessante. Eu gosto dessa facilidade de acesso".

O sujeito coletivo, em seu discurso, no entanto, reconhece que nem todos os clientes adotam o local onde a loja está situada no shopping como um fator determinante para se escolher determinada loja. Ele considera que outros atributos como uma boa qualidade dos produtos, um bom ambiente de marketing, um bom atendimento etc. são mais decisivos para a escolha destes clientes do que a localização.

"No entanto, eu acho que para algumas pessoas, o local onde a loja está situada (no shopping) não é tão decisivo na hora de fazer uma compra. Eu creio que se elas já vão com uma coisa em mente, independentemente de onde a loja esteja, elas acabam indo até lá. Além disso, se elas conhecem a tradição da loja, a qualidade do produto, se sabem que vão ser bem atendidas, que a loja vai ter as instalações adequadas (...), o local dentro do shopping onde a loja se encontra não é importante, eu creio, porque elas vão procurar essa loja, independentemente de qual andar ela esteja. Várias vezes, eu já vi pessoas recorrendo aos mapas de localização do shopping para ver onde é que estava a loja onde desejavam comprar. Então, eu penso que, certamente, a localização da loja dentro do shopping não tem diferença nenhuma para elas na hora de decidir comprar. Eu acredito que se estes clientes confiam na loja, eles não vão se importar em subir mais dois ou três andares ou de descer mais um ou dois porque eles já têm a sua preferência assegurada por determinada loja. Uma vez, eu até conversei com um parente sobre por que ele comprava naquela loja de roupas, que tinha um acesso ruim, no quarto piso, tendo que pegar elevadores geralmente lotados. Ele me disse que se a loja possui um atendimento de qualidade e produtos idem, não importa para ele se a loja está no primeiro ou no último andar (...), próxima às entradas e/ou saídas (...), isto tudo, para ele, é irrelevante". 
A tabela 14 destaca o compartilhamento das Ideias Centrais (IC) obtidas nos depoimentos dos atores sociais entrevistados nesta pesquisa, referentes à pergunta 10.

Tabela 14: o valor percebido pelo cliente como antecedente de sua fidelização à loja.

10. Paulo compra na loja "ABC" porque, na sua avaliação, os benefícios de loja obtidos (ambiente, imagem, prestígio e localização) são maiores do que os esforços prévios (monetários e não monetários) que ele tem para comprar lá. Você acredita que esta situação é capaz de tornar Paulo fiel à loja?

Ideias Centrais

A $\quad$ O valor percebido pelo cliente o fideliza a certa loja.

B O que o cliente busca mesmo é o menor preço.

Fonte: QualiQuantiSoft@ (2015)

DSC 10: o valor percebido pelo sujeito coletivo como possível fonte de sua fidelização a certa loja.

O sujeito coletivo reconhece que o ambiente de loja, sua imagem, seu prestígio e sua localização são atributos que, em maior ou menor grau, contribuem para lhe gerar benefícios não monetários, tais como: economia de tempo, redução de estresse, satisfação com a experiência de compra, reconhecimento social etc. Afirma que está disposto, em nome destes benefícios, a algum sacrifício financeiro, desde que este não implique em gastos descomedidos em relação ao seu orçamento. Ele confirma que estes benefícios são realmente importantes para sua fidelização a determinada loja.

"Eu acredito que sim porque são valores que a loja vai construindo perante o consumidor e isso o traz de volta. O cliente volta a comprar ali porque se sentiu seguro: teve um bom retorno, um produto que durou o tempo que deveria durar, custou o quanto ele acredita que valeria e tem um bom atendimento, além da loja possuir um ambiente legal de compra. Atualmente existem muitos clientes que vão em busca do menor preço, sem se preocupar tanto com a qualidade dos produtos. Por outro lado, existem aqueles que vão em busca de 
valores. Então, para mim, isso faz uma grande diferença. Eu busco lojas com esse pensamento, com esse posicionamento sem dúvida, porque aí eu não estou indo comprar preço, mas bom serviço, bom atendimento. É importante o cliente saber que independentemente do dinheiro que ele vai gastar para chegar até a loja, ele sabe que vai ter a mercadoria que deseja, que vai ser bem atendido e, principalmente, que se tiver qualquer tipo de problema, ele vai ser solucionado. Então às vezes é melhor gastar um pouco mais para se ter um atendimento muito bom do que gastar um pouco menos e ser muito mal atendido. Eu acredito que todos esses benefícios tornam o cliente fiel à loja, não tenho dúvida, pois se tem tudo isso disponível, não irá perder tempo em procurar outra loja, principalmente por conta da correria dos tempos modernos. Vale destacar que isto é particularmente importante com produtos que você tem um envolvimento maior. Não tenho dúvida que o preço não é o principal. Óbvio que você tem um valor, não vou pagar X vezes, duas, três, quatro vezes mais. Agora, dado um preço razoável, um acréscimo de preço razoável, não tenho a menor dúvida, eu o cliente vai preferir comprar na loja onde tenha um atendimento melhor, uma loja mais bem organizada, uma loja que já conheça, uma loja que tenha uma localização acessível, tudo isso ele vai valorizar. Para que uma loja tenha esse cliente fiel, ela tem que oferecer todos esses benefícios para ele sentir que vale a pena comprar na loja. Às vezes o preço dessa loja é um pouco acima do mercado, mas eu, como cliente, acho que eu compraria mesmo que o preço fosse um pouco mais alto, porque o benefício que eu tenho vale mais. Então, desde que não seja um preço muito acima do valor de mercado, eu volto a comprar sim e me sinto totalmente valorizado. Todos esses benefícios são muito importantes, só que você também tem que ter um parâmetro de mercado para se guiar. Acredito que, por mais que eles estejam te oferecendo aqui tudo de bom, tudo de atraente para você adquirir um produto, tudo também tem o seu preço. Então acho que isso, para mim, é fundamental, a noção de limite". 
Mesmo reconhecendo a importância dos benefícios não meramente financeiros para que o cliente possa se fidelizar à determinada loja, o sujeito coletivo acredita que uma grande parte das pessoas ainda opta mesmo é pela economia, ou seja, a busca pela oferta, pelos descontos. Ele afirma ainda que alguns clientes até podem valorizar a conveniência, a comodidade, a qualidade etc., mas eles estarão sempre se perguntando até quanto aquilo vale a pena.

"Eu percebo que as pessoas estão buscando praticidade, comodidade, sobretudo, hoje, quando elas se veem cada vez mais pressionadas. Elas estão dispostas a pesquisar muito para obterem as melhores opções. Agora, não se pode negar que a maioria delas presta atenção ao montante desembolsado para ter se comprar alguma mercadoria (...). Eu acho que a maioria dos clientes ainda pensa assim. $\mathrm{Na}$ verdade, o que os clientes buscam, na maior parte das vezes, é preço baixo. Eles não se preocupam muito com outros benefícios que não sejam de ordem financeira (...). Eu conheço pessoas, frequentadoras de shoppings, que visitam várias lojas em busca de um produto e o seu critério de decisão para escolher alguma loja passa ou pelo menor preço ou pelas condições de pagamento. Então, fica claro para mim que outros critérios como atendimento, acessibilidade à loja, sinalização, sortimento de mercadorias nem sempre são devidamente valorizados por algumas pessoas (...). Eles estarão sempre se perguntando se isto vale a pena para ter de se pagar mais caro (...)". 
No que se refere ao primeiro objetivo, o de verificar se o ambiente da loja era um atributo relevante para se gerar valor não monetário de loja percebido pelo cliente, a coletividade retratada nos discursos, revelou que os clientes acreditam que a música ambiente e a iluminação geram benefícios para a experiência de compra do cliente, desde que devidamente projetados dentro do design interno da loja. O layout e a disponibilidade de mercadoria na loja foram lembrados em função de agregar conveniência e comodidade aos clientes, sobretudo em relação à economia de tempo. Já em relação ao desempenho dos vendedores, a coletividade enfatizou a capacidade técnica e o nível de atendimento como benefícios reais percebidos, mas vê a presença do vendedor desnecessária quando percebe que estes estão mais interessados em comissões e bonificações de vendas, tentando lhe "empurrar" todo tipo de produto.

No que se refere ao objetivo de verificar se a imagem corporativa da loja situada em um shopping era um elemento relevante na geração de valor não monetário de loja percebido pelo cliente, a coletividade revelou que alguns clientes percebem uma boa imagem da loja como sinônimo de qualidade dos produtos e de credibilidade dos seus serviços. No entanto, viu-se, também que, para alguns clientes, embora uma boa imagem possa ser uma referência para se indicá-la a alguém, ela não teria o grande poder de fazer com que os clientes se tornassem fiéis a esta loja.

Em relação ao objetivo de descobrir se o prestígio da loja situada em um shopping center, em função de sua tradição de mercado, seria uma variável relevante para se gerar valor não monetário de loja percebido pelo cliente, este estudo, por meio do DSC, revelou que embora alguns clientes percebessem que uma loja com longa existência significasse confiabilidade em seus produtos e serviços, outros não atribuíram importância a este atributo para sua decisão de compra, pois, segundo eles, uma loja com menos tempo de existência no mercado pode também oferecer as mesmas qualidades de produto e serviço das tradicionais. 
Em relação ao objetivo de se descobrir se o local onde a loja está situada no interior do shopping seria um elemento relevante para a geração de valor não monetário de loja percebido pelo cliente, por meio dos discursos do sujeito coletivo, constatou-se que alguns clientes atribuíram relativa importância a este tópico, alegando que o fácil acesso à loja é um benefício importante em função da comodidade e conveniência, sobretudo nos dias atuais, com o tempo cada vez mais parecendo exíguo para algumas pessoas. Por outro lado, o estudo verificou que alguns clientes informaram que o que mais importava para eles era a qualidade dos produtos e o nível de atendimento na loja. Se isto fosse satisfeito, eles estariam dispostos a ir até a loja, independentemente de onde estivessem localizadas no shopping.

E em relação ao problema de pesquisa, ou seja, verificar se o valor de loja percebido pelo cliente seria importante para produzir sua lealdade à determinada loja localizada dentro de shopping centers, este trabalho, por meio da metodologia do DSC calcada nas representações sociais foi de importância fundamental para se descobrir que os clientes entendem que os benefícios não monetários são sim fonte de fidelização à determinada loja. Eles também entendem que é necessário um certo sacrifício financeiro para receber estes benefícios. Mas lembraram que, geralmente, alguns clientes se impõem limites financeiros para obterem estes benefícios. 
Os resultados apresentados nesta pesquisa nos permitem discutir temas importantes em relação ao DSC apresentados para as IC que representaram o problema de pesquisa, os objetivos e as hipóteses de trabalho propostas.

Já no início em relação à pergunta de triagem dos respondentes, a fim de se verificar a sua fidelidade a certa loja, foram geradas cinco IC, discutidas a seguir. Nota-se que os clientes, pertencentes à coletividade retratada nos discursos, reconhecem ser:

\section{IC: fiéis à loja pela qualidade dos seus produtos.}

Entendem a importância de uma loja dispor de mercadorias de qualidade, algo tangível, para que eles mantenham uma relação de fidelidade com a loja. Este fato também contribui para que eles se sintam seguros para recomendar a loja para outros potenciais clientes. Em função do reconhecimento da qualidade das mercadorias, os clientes evidenciam sua disposição em pagar um pouco mais para obtê-las. O que percebemos, claramente é que um ponto crucial para a fidelização destes clientes é o lojista contar com um produto de excelência, sem o que qualquer ação de marketing será contraprodutiva neste sentido. Ainda que o cliente seja convencido a visitar a loja, ele não a considerará em seu conjunto de escolha, termo cunhado por Kotler e Keller (2006) para se referirem ao leque de opções de fornecedores concorrentes levados em conta pelos clientes quando aqueles satisfazem certos atributos considerados importantes por estes.

\section{IC: fiéis à loja pelo seu nível de atendimento.}

Da mesma forma, apontam para a importância da qualidade do atendimento como condição para que continuem comprando ali. Este é um fator que, embora óbvio, costuma ser bastante 
negligenciado pelos lojistas. Neste caso, é importante destacar que os gestores de loja possuem um papel crucial na capacitação de seus funcionários de suporte e, principalmente, de vendas.

\section{IC: fiéis à loja por sua organização interna.}

Algo relevante nas respostas dos clientes, encontrado no DSC, é a preocupação deles em relação à organização interna da loja como condição para continuarem comprando lá. A organização interna da loja é um componente importante do seu layout, que, por sua vez, compõe o ambiente de loja. Estes clientes querem comodidade e conveniência e, por conta disto, ressaltaram a importância de uma loja bem sinalizada, com arquitetura atraente e com mercadorias devidamente expostas. Aqui, cabe ressaltar, mais uma vez, uma atuação decisiva dos gestores de loja para que sejam eficientes na busca de um ambiente de loja verdadeiramente agradável para seus clientes. Estes devem se sentir alegres com sua experiência de compra e, para isto, as lojas devem ser bem sinalizadas, com mercadorias adequadamente expostas a fim de despertar o interesse dos clientes em manter relacionamentos comerciais duradouros.

\section{IC: fiéis à loja pela afinidade com a marca dos produtos que a loja vende.}

O discurso do sujeito coletivo mostra que alguns clientes ainda são suscetíveis à escolha de determinadas marcas ao decidirem comprar em sua loja. Isto revela que os gestores de loja devem estar atentos ao trabalho de gerenciamento da imagem das marcas que comercializa, sejam as próprias ou a de terceiros. Neste último caso, uma política de parcerias mostra-se extremamente salutar.

\section{IC: fiéis à loja pela disponibilidade de mercadorias.}

Os clientes retratados nos discursos também mostraram que uma das razões para que eles se sintam fiéis à determinada loja reside em sua confiança na capacidade de sua loja dispor das 
mercadorias que desejam. Isto é um recado importante para que os gestores de loja se preocupem em não permitir stockout de suas mercadorias. Gestão eficaz de estoque permite que o lojista evite a perda de potenciais clientes, aumentando, possivelmente, o tíquete médio, ou seja, os gastos dos clientes durante sua visita à loja.

Já em relação ao tema música, variável do ambiente de loja, os clientes representados nos discursos produziram as seguintes ideias centrais:

\section{IC: a música ambiente agrega valor pelo posicionamento da loja.}

Algo importante apontado pelos clientes, no DSC, é a capacidade de a música ambiente apontar corretamente o perfil da loja, facilitando sua identificação com os segmentos-alvo que deseja atingir. Desta forma, uma importante orientação é passada aos gestores destas lojas por seus clientes: a trilha musical deve ser pensada em termos de identidade de loja, ou seja, ela deve transmitir adequadamente os conceitos e os valores da loja de maneira a atingir o gosto daqueles frequentadores que se identificam com sua proposta de negócios.

\section{IC: a música ambiente agrega valor por tornar o ambiente de loja aprazível.}

Os clientes, por meio do DSC amparado em suas representações sociais, afirmaram ainda que a música torna a experiência de compra na loja mais agradável, pois faz com que eles se sintam menos estressados, mais cômodos para escolher as mercadorias que desejam. É oportuno salientar, por meio das ideias aqui expostas pelos clientes, que a música ambiental é uma variável que traz benefícios psicológicos de compra para os clientes, agregando-lhes valor. Desta forma, os gestores de loja não podem prescindir dela em suas ações de relacionamento com seus clientes. No entanto como podemos perceber pela IC abaixo: 


\section{IC: A música ambiente não agrega valor quando não é bem conceitualmente pensada em termos de volume, trilha musical etc.)}

A música ambiente deve ser utilizada parcimoniosamente de maneira a agradar os clientes e não se tornar uma fonte de ruído desagradável. Alguns clientes até comentaram que a música inadequadamente tocada exercia neles um efeito contrário, ou seja, eles se desestimulavam em comprar naquela loja.

Quando o tema iluminação foi explorado com os clientes, viu-se que os clientes, espelhados nos discursos coletivos, a consideraram um benefício importante em sua experiência de compra por duas razões:

\section{IC: a iluminação agrega valor por destacar os produtos da loja.}

Aqui, os clientes apontaram que a iluminação tem a capacidade de destacar as mercadorias, facilitando sua manipulação pelo cliente. Em outras palavras, a iluminação permite que os clientes consigam avaliar tanto as características intrínsecas quanto extrínsecas das mercadorias em pormenores como, por exemplo, no caso de vestuários, sua textura, seu acabamento, sua cor etc.

\section{IC: a iluminação agrega valor por destacar o ambiente de loja}

Também destacaram o papel da iluminação em tornar o ambiente de loja estético e funcional: no primeiro caso, ao valorizar a arquitetura e o design interno da loja; no segundo, ao permitir ao facilitar o deslocamento das pessoas em seu interior, projetando-lhe conforto. Os clientes, em todas as suas falas, apontaram para um uso racional da iluminação na ambientação da loja. Por fim, os clientes entrevistados reconhecem a iluminação como benefícios, fonte de geração de valor. Em função do que aqui foi apurado, os gestores de loja devem ter um cuidado 
especial no que tange à iluminação interna da loja para prover um ambiente de loja atrativo para os seus clientes, adequada aos gostos e exigências dos mesmos, pois os clientes deixaram claro que:

\section{IC: a iluminação não agrega valor quando não é bem conceitualmente pensada em termos de intensidade, por exemplo.}

Isto é, a iluminação não pode ser fonte de desconforto para os clientes da loja, nem por escassez nem por excessos. Lojas muito intensamente iluminadas tiveram um efeito nocivo aos olhos de seus frequentadores como pudemos ver, ao passo que lojas muito pouco iluminadas geraram dúvidas destes clientes sobre a qualidades das mercadorias ali expostas.

Em relação ao tema layout como forma de agregação de valor para os clientes, a coletividade de clientes representada nos discursos gerou duas ideias centrais:

\section{IC: o layout agrega valor pela comodidade da localização do produto.}

Os respondentes afirmaram que a principal função do layout é promover o fácil acesso dos clientes às mercadorias por meio de uma excelente arrumação efetuada pela loja. Eles argumentam que a disposição das mercadorias por modelo, numeração, cor etc. é um benefício importante para eles porque permite-lhes otimizar seu tempo, um fator extremamente valorizado por todos hoje em dia. Este discurso destaca o layout em seu aspecto mais singular, o de organização dos produtos por meio de gôndolas, araras etc.

\section{IC: o layout agrega valor por favorecer a organização da loja.}

Neste caso, o layout foi apontado como tendo um papel significativo na ambientação da loja em si, ou seja, em seu aspecto mais amplo. Em outras palavras, o layout permite que os clientes possam se locomover com mais agilidade dentro da loja, tornando sua estadia na loja 
mais prazerosa. Como podemos perceber, mais uma vez, a plenitude dos clientes entrevistados atribuiu uma importância ímpar para o layout como um benefício em suas experiências de compra, reconhecendo, portanto, sua capacidade de gerar valor percebido. A conveniência e o tempo foram apontados por estes clientes como essenciais em sua escolha por determinada loja e, portanto, não estão dispostos a sacrificarem seu tempo com lojas mal sinalizadas. Desta forma, os gestores de loja devem dar total atenção a este quesito, adotando ações de design interno que favoreçam o cliente durante sua permanência na loja: espaços amplos entre gôndolas, corredores sem muitas mercadorias expostas, boa sinalização etc.

Quando o tema coberto se referiu à disponibilidade das mercadorias na loja como fonte geradoras de valor, os clientes representados nos discursos geraram duas ideias centrais:

\section{IC: a disponibilidade de mercadorias agrega valor para o cliente pela comodidade da economia de tempo.}

Apontaram que a disponibilidade de mercadorias é um benefício importante em função de sua limitação de tempo para realizar pesquisas entre lojas. Em metrópoles onde, cada vez mais, os deslocamentos internos tornam-se complicados, o cliente quer maximizar seu tempo, de maneira a realizar o maior número possível de atividades relacionadas não somente a compras, mas ao lazer, à família etc.

\section{IC: a disponibilidade de mercadorias agrega valor para o cliente pela comodidade da economia dos outros custos de pesquisa.}

Eles também enfatizaram a importância da disponibilidade de mercadorias associadas à redução de outros custos de pesquisa, financeiros e não financeiros, ao lembrarem, por exemplo, o gasto com estacionamentos, com alimentação, estresse psicológico com trânsito, busca por vagas etc. Portanto, evidencia-se a disponibilidade das mercadorias como um benefício importante valorizado por estes clientes. O que podemos inferir, então, é o cuidado redobrado que os lojistas devem ter em relação a este atributo, evitando o stockout de 
mercadorias. Para isso, devem possuir uma administração eficaz de seus estoques e de compras, evitando a perda destes clientes e inibindo a entrada de outros potencias compradores (prospects).

O próximo objetivo investigado, que se refere ao papel dos vendedores como fontes geradoras de valor, a coletividade representada nos discursos gerou duas IC.

IC: os vendedores, quando bem treinados, agregam valor ao cliente por seus conhecimentos técnicos.

Os respondentes afirmaram serem os vendedores muito úteis para a indicação de mercadorias em função de sua expertise. É uma constatação importante ver que os clientes aprovam o vendedor como um conselheiro, solicitando-lhe sugestões, apoio técnico para tomarem a melhor decisão de compra. Isto atesta, pelo menos em um primeiro momento, que, para estes clientes, o autosserviço não é uma opção viável. Também revela clientes dependentes de conselhos, sobretudo quando se referem a bens duráveis, que tendem a ser mais caros.

IC: vendedores, quando bem treinados, agregam valor ao cliente por seu nível de atendimento.

Os clientes julgam relevantes a presença dos vendedores em sua experiência de compra, ou seja, gostam quando os vendedores lhes mostram mais opções de mercadorias, quando lhes explicam as formas e condições de pagamento, quando lhes acolhem de maneira cordial. Para estes clientes, o vendedor atua como um item essencial em sua decisão de se tornar fiel a uma loja. 


\section{IC: os vendedores não agregam valor quando colocam seus interesses pessoais em primeiro plano em detrimento dos do cliente}

Para os gestores de loja que atuam com vendedores fica a importante missão de treinar seus funcionários para que prestem um serviço de atendimento superior, evitando conflitos que impeçam o retorno do cliente à loja. Em outras palavras, o vendedor não pode e nem deve priorizar seus interesses financeiros (comissões, bônus por vendas) em detrimento dos do cliente. Isso fatalmente se converterá em fonte de ruptura destes clientes com a loja, conforme se evidencia na ideia central acima.

O próximo tema investigado foi se a imagem da loja era um benefício para os seus clientes, ou seja, se lhes agregava valor. Neste sentido, a coletividade representada nos discursos produziu as seguintes IC.

IC: a imagem corporativa da loja agrega valor por transmitir confiabilidade, segurança.

Os respondentes informaram acreditar que a imagem corporativa da loja é um benefício incontestável. Disseram que produtos de qualidade, política de trocas flexível e, principalmente, serviços de pós-venda são essenciais para que ele opte por determinada loja. Para os gestores de lojas, fica uma importante missão de saber administrar com eficiência a imagem da loja, sinalizando para seus compradores diferenciais considerados relevantes por estes. Assim, são essenciais uma boa política de comunicação para divulgar as qualidades das mercadorias que vende; uma boa execução dos serviços pós-venda a fim de garantir a satisfação dos clientes, como políticas flexíveis de troca e devolução (logística reversa)

\section{IC: a imagem corporativa da loja nem sempre é sinônimo de benefício para alguns clientes.}

Os respondentes afirmaram que algumas vezes, o fato de clientes revelarem preocupações com a qualidade dos produtos, assistência técnica mostra, apenas, que eles valorizam certos 
atributos que podem não ser valorizados por outros. Neste caso, é importante que os gestores saibam efetivamente que atributos de loja são mais relevantes para seus clientes de maneira a fortalecer a imagem de uma loja comprometida com a satisfação deles.

O próximo tema coberto, foco deste estudo, era saber se o prestígio, simbolizado pela tradição de mercado da empresa, era um benefício para os clientes em suas decisões de compra em determinada loja. A coletividade, espelhada nos discursos, gerou duas IC antagônicas:

\section{IC: o prestígio da loja nem sempre é um atributo relevante para a decisão do cliente de comprar em determinada loja.}

Alguns respondentes afirmaram que o prestígio de uma loja nem sempre é um atributo que traga benefícios concretos para seus clientes, argumentando que nem toda loja com tradição de mercado, reconhecida, seja realmente sinônimo de credibilidade. Argumentam que muitas destas lojas acabam se acomodando, por tanto tempo de existência, nos serviços e no atendimento. Por outro lado:

\section{IC: o prestígio da loja agrega valor para o cliente, sendo um elemento relativamente importante para a sua decisão de compra.}

Outros atribuem um papel relativamente relevante ao prestígio como fonte geradora de valor percebido. Segundo estes clientes, uma loja com tradição de mercado é um símbolo de confiabilidade, pois se estão há muito tempo, infere-se que algo de bom tenham para oferecer aos seus clientes, como produtos de qualidade, boa prestação de serviços, status etc. Neste ínterim, vale ressaltar aos gestores de lojas tradicionais que fortaleçam sua imagem de credibilidade junto aos seus clientes, adotando políticas de comunicação que realcem este atributo. Os sites destas empresas podem ser úteis ao revelar aspectos institucionais e sua trajetória histórica de sucesso. 
O próximo objetivo a ser coberto, que era o de investigar as opiniões dos clientes sobre se o local onde a loja estava situada dentro do shopping lhes agregava valor percebido, as opiniões foram praticamente equivalentes em dois sentidos opostos, conforme pode se empreender nas IC seguintes:

\section{IC: o local onde a loja está situada no shopping nem sempre é um critério relevante para a decisão do cliente de comprar em determinada loja.}

Para alguns, o local onde a loja se situa no shopping não é um atributo primordial na sua decisão de comprar em determinado estabelecimento. Portanto, a localização não lhes agrega grande valor percebido. Estes clientes tomam suas decisões de comprar ou não em determinada loja baseados em outros atributos como a qualidade do produto, o nível de atendimento, as instalações da loja etc. Afirmam que as lojas que atendem a estas exigências de qualidade, independentemente de onde estejam localizadas no shopping, serão consideradas em seu conjunto de escolha.

\section{IC: o local onde a loja está situada no shopping agrega valor para o cliente, influenciando-o em sua decisão de compra.}

Já outros clientes sinalizaram no sentido de que o local da loja no shopping exerce alguma influência em sua decisão para comprar em determinada loja. O fácil acesso a estas lojas, segundo estes clientes, propicia conveniência e ganho de tempo. Neste caso, a conveniência é traduzida em economia de esforço físico (proximidade das entradas e saídas do shopping), na redução de estresse (por já saber onde a loja se encontra). Já a economia de tempo ocorre, por exemplo, segundo estes clientes, quando estas lojas estão situadas próximas a lojas âncoras, varejistas os quais costumam frequentar. Para os lojistas cabe uma investigação mais criteriosa sobre se o perfil de seus potencias clientes, ou seja, aqueles que pretende atingir, e mesmo os seus clientes atuais, é no sentido de valorizar ou não a localização da loja. Os administradores de shopping projetam suas taxas de aluguéis baseados na localização da loja. 
Seria, portanto, interessante o lojista saber se sua localização interfere ou não na preferência destes clientes para, assim, buscar boas negociações, não somente em termos financeiros, mas por melhores espaços.

O problema de nossa pesquisa buscava responder à questão do valor percebido pelos clientes como um fator relevante para sua fidelização a certa loja. A partir desta contextualização, a coletividade, por meio dos discursos, gerou duas IC antagônicas:

\section{IC: o que o cliente busca mesmo é o menor preço.}

Embora não enfaticamente, alguns poucos respondentes afirmaram que os atributos relacionados ao ambiente, à imagem, ao prestígio etc. não eram benefícios claramente percebidos por alguns clientes e o que estes efetivamente buscavam saber era se valia a pena pagar por isto.

\section{IC: o valor percebido pelo cliente, na perspectiva dos benefícios, o fideliza a certa loja.}

Outros, de maneira mais expressiva, apontaram no sentido de que os atributos de loja como o seu ambiente, sua imagem, seu prestígio e o local onde ela está situada no shopping são benefícios tangíveis para os clientes, sendo superiores aos esforços financeiros e não financeiros (custos de pesquisa, psicológicos, de tempo etc.) envolvidos na transação. Para estes respondentes, o cliente percebe o valor percebido, na ótica dos benefícios, como um direcionador para escolher determinada loja em detrimento de outra e permanecer leal a ela. Para os gestores de loja é prudente tecer algumas considerações:

- O ambiente de loja, especificamente em relação aos itens aqui analisados, como música e iluminação (ambientais), layout e disponibilidade de mercadorias (design), e o atendimento dos vendedores (sociais), em maior ou menor grau, segundo os clientes participantes, são fontes de benefícios e, portanto, devem 
ser adotadas ações de marketing pelos lojistas que maximizem a percepção dos compradores quanto à eficiência no oferecimento destes atributos.

- Uma boa imagem corporativa da loja foi apontada pelos clientes como sinônimo de credibilidade para se manter um relacionamento comercial. Entre os principais itens apontados por eles, a qualidade das mercadorias e um nível de excelência nos serviços de pós-venda foram os que geraram maior percepção de imagem corporativa. Portanto, os lojistas, sobretudo aqueles que não oferecem marcas próprias, devem encetar políticas de acompanhamento de produção destas mercadorias junto aos seus fornecedores para garantir níveis altos de qualidade. Em relação aos seus serviços, o lojista deve sempre empreender esforços para que seus processos sejam flexíveis para favorecer os seus clientes em suas demandas; e seus funcionários, ágeis para respondê-las.

- O prestígio da loja, traduzido aqui pelo tempo de existência da loja no mercado, foi medianamente percebido pelos clientes como um atributo gerador de valor. Ainda assim, a loja deve buscar impactar seus clientes atuais e potenciais, comunicando-lhes sua marca histórica como símbolo de credibilidade.

- O local onde a loja está situada dentro do shopping também foi um atributo medianamente entendido como um benefício, ou seja, como uma fonte geradora de valor. Cabe ao gestor, como citado anteriormente, descobrir qual o impacto da localização para seus clientes e, assim, buscar formas de negociação junto aos administradores de shopping buscando esses locais. 


\subsection{Limitações da pesquisa.}

Uma primeira limitação desta tese diz respeito à revisão da literatura. Embora tenha havido uma extensa revisão bibliográfica, foi impossível apresentar toda a literatura concernente aos temas abordados, sobretudo em relação ao conceito de valor percebido. O conflito de conceitos sobre valor também contribuiu para que uma única perspectiva fosse adotada.

Por seu caráter exploratório, os resultados deste trabalho não podem ser generalizados. Portanto, cabe mencionar que as descobertas desta pesquisa são afeitas somente aos atores sociais participantes deste estudo.

As entrevistas foram realizadas com clientes das classes B e C, de acordo com o critério Brasil, da Associação Brasileira de Empresas de Pesquisa (ABEP). Isto é uma limitação importante, tendo em vista que estes clientes tendem, pelo menos em tese, a serem menos suscetíveis a preço. Clientes de outras classes poderiam ter sido incluídos, o que geraria resultados diferentes com maior ou menor nível de detalhamento.

Os dados foram analisados por meio do Discurso do Sujeito Coletivo (DSC), de natureza subjetiva, portanto dependente da interpretação do pesquisador durante todo o processo de análise.

Por fim, cabe salientar que o conceito de valor percebido de loja, embora amplamente discutido neste trabalho, foi baseado somente na ótica dos benefícios. Outros resultados teriam sido obtidos se fosse adotada a perspectiva do benefício social, por exemplo. 


\subsection{Sugestões para pesquisas futuras.}

O trabalho revelou que o valor percebido pelo cliente, na perspectiva dos benefícios, é um atributo relevante para sua fidelização à sua loja. Aqui, a perspectiva adotada foi a dos benefícios. Outros trabalhos poderiam avaliar a opinião dos clientes sobre o valor percebido de loja a partir da ótica dos benefícios sociais.

Ainda como sugestão de pesquisa, esta metodologia poderia ser reproduzida para outros grupos de clientes pertencentes a classes diferentes das aqui selecionadas, a fim de comparar os resultados apontados neste trabalho.

Recomenda-se, também, a aplicação de trabalhos quantitativos para se verificar a possível validade e a generalização dos resultados aqui obtidos.

Recomenda-se, ainda, a aplicação de estudos quantitativos para se verificar o grau de influência do valor de loja percebido, na perspectiva dos benefícios, na fidelização do cliente em lojas situadas fora do shopping center. 


\section{REFERÊNCIAS}

ABRASCE. Disponível em:

<http://www.portaldoshopping.com.br/site/monitoramento/evolucao-do-setor>. Acesso em 01/07/2015.

ACHABAL, Dale D. et al. Multiloc: a multiple store location decision model. Journal of Retailing. V. 58, n. 2, p. 5-21, 1982.

AGARWAL, Sanjeev; TEAS, R. Kenneth. Perceived value: mediating role of perceived risk. Journal of Marketing Theory and Practice, v. 9, n. 4, p. 1-14, 2001.

AL-SABBAHY, Hesham Z., et al. An investigation of perceived value dimensions: implications for hospitality research. Journal of Travel Research. V. 42, n. 3, p. 226-234, 2004.

ANDRADE, Maria Margarida de. Introdução à metodologia do trabalho científico: elaboração de trabalhos na graduação. $4^{a}$ ed. São Paulo: Atlas, 1999.

ARENI, Charles S.; KIM, David. The influence of in-store lighting on consumers' examination of merchandise in a wine store. International Journal of Research in Marketing. V. 11, n. 2, p. 117-125, 1994.

BABIN, Barry J.; ATTAWAY, Jill S. Atmospheric affect as a tool for creating value and gaining share of customer. Journal of Business Research. V. 49, n. 2, p. 91-99, 2000.

BACKSTROM, Kristina; JOHANSSON, Ulf. Creating and consuming experiences in retail store environments: comparing retailer and consumer perspectives Journal of Retailing and Consumer Services. V. 13, n. 6, p. 417-430, 2006.

BAEK, Tae Hyun et al. The differential roles of brand credibility and brand prestige in consumer brand choice. Psychology \& Marketing. V. 27, n. 7, p. 662-67, 2010.

BAKER, Julie et al. The influence of multiple store environment cues on perceived merchandise value and patronage intentions. Journal of Marketing. V. 66, n. 2, p. 120-141, 2002.

BATEMAN, Connie; VALENTINE, Sean. The impact of salesperson customer orientation on the evaluation of a salesperson's ethical treatment, trust in the salesperson, and intentions to purchase. Journal of Personal Selling \& Sales Management. V. 35, n. 2, p. 125-142, 2015. 
BEHRMAN, Douglas N.; PERREAULT JR, William D. Measuring the performance of industrial salespersons. Journal of Business Research. V.10, n. 3, p. 355-370, 1982.

BERG, Bruce Lawrence. Qualitative research methods for the social sciences. $7^{\mathrm{a}}$ ed. Boston: Allyn \& Bacon, 2009.

BLOCH, Peter H. et al. The shopping mall as consumer habitat. Journal of Retailing. V.70, n. 1, p. 23-42, 1994.

BLOEMER, Josée; RUYTER, Ko de. On the relationship between store image, store satisfaction and store loyalty. European Journal of Marketing. V. 32, n. 5/6, p. 499-513, 1998.

BOKSBERGER, Philipp E; MELSEN, Lisa. Perceived value: a critical examination of definitions, concepts and measures for the service industry. Journal of Services Marketing. V. 25, n. 3, p. 229-240, 2011.

BURT, Steve; CARRALERO-ENCINAS, Jose. The role of store image in retail internationalization. International Marketing Review. Vol. 17, n. 4/5, p. 433 - 453, 2000. CALLARISA, Luis J. et al. Multidimensional perspective of perceived value in industrial clusters. Journal of Business \& Industrial Marketing. V. 26, n. 2, p. 132-145, 2011.

CARPENTER, Jason M; FAIRHURST, Ann. Consumer shopping value, satisfaction, and loyalty for retail apparel brands. Journal of Fashion Marketing and Management. V. 9, n. 3, p. 256-269, 2005.

CHEBAT, Jean-Charles et al. How does shopper-based mall equity generate mall loyalty? A conceptual model and empirical evidence. Journal of Retailing and Consumer Services. V. 16, n. 1, p. 50-60, 2009.

CHEN, Chien-Chung; JARAMILLO, Fernando. The double-edged effects of emotional intelligence on the adaptive selling-salesperson-owned loyalty relationship. Journal Of Personal Selling \& Sales Management. V.34, n. 1, p. 33-50, 2014.

CRAIG, C. S. et al. Models of the retail location process: a review. Journal of Retailing. V. 60, n. 1, p. 5-36, 1984.

DABHOLKAR, Pratibha A. et al. A measure of service quality for retail stores: scale development and validation. Journal of the Academy of Marketing Science. V. 24, n. 1, p. 3-16, 1996.

DAWSON, John; LORD, Dennis (Ed.). Shopping Centre Development (RLE Retailing and Distribution). Routledge, 2012.

DAWSON, Scott. An exploration of the store prestige hierarchy reification, power, and perceptions. Journal of Retailing. V. 64, n. 2, p. 125-126, 1988. 
DEETER-SCHMELZ, D. et al. Measuring the prestige profiles of consumers: a preliminary report of the PRECON scale. In: ENGELLAND, B.; SMART, D. (Eds.). Marketing foundations for a changing world: proceedings of the annual meeting of the southern marketing association, Southern Marketing Association, Orlando, FL, p. 395-399, 1995.

DES ROSIERS, François et al. Do chain affiliation and store prestige affect shopping center rents. In $18^{\circ}$ Annual European Real Estate Society Conference. ERES: Conference.

Eindhoven, the Netherlands, 2011.

DIVARIES, Cosmas Jaravaza; CHITANDO, Patience. The Role of Store Location in Influencing Customers' Store Choice. Journal of Emerging Trends in Economics and Management Sciences. V 4, n. 3, p. 302-307, 2013.

DODDS, William B. et al. Effects of price, brand, and store information on buyers' product evaluations. Journal of Marketing Research. V. 28, n. 3, p. 307-319, 1991.

DUBOIS, Bernard; CZELLAR, Sandor. Prestige brands or luxury brands? An exploratory inquiry on consumer perceptions. P. 332-658. http://archive-ouverte.unige.ch/unige:5816 Acesso em 14/09/2015.

ERRAGCHA, Nozha; GHARBI; Jamel-Eddine. Moderating effect of accompaniment on the relationship between online perceived quality and perceived value. Asian Journal of Business Management. V. 4, n. 3, p. 260-266, 2012.

FALCÃO, Eliane Brígida Morais; FARIA, Flavio Silva. Os sentidos de natureza na formação e na prática científica . Educação e Pesquisa, Brasil, v. 33, n. 2, p. 335-351, 2007.

FEINBERG Richard A.; MEOLI, Jennifer. A Brief History of the Mall. Advances In Consumer Research. V.18, n. 1, p. 426-427, 1991.

FLICK, Uwe. (2004). Uma introdução à pesquisa qualitativa. (2a ed.). (S. Netz, Trad.). Porto Alegre: Bookman.

FULLERTON, Gordon. When does commitment lead to loyalty? Journal of Service Research. V. 5, n. 4, p. 333-344, 2003.

GALLARZA, Martina G.; SAURA, Irene Gil. Value dimensions, perceived value, satisfaction and loyalty: an investigation of university students' travel behaviour. Tourism Management. V. 27, n. 3, p. 437-452, 2006.

GAMMOH, Bashar. S. et al. Antecedents and consequences of salesperson identification with the brand and company. Journal Of Personal Selling \& Sales Management. V. 34, n. 1, p. 3-18, 2014. 
GIL, Antônio Carlos. (2002). Como elaborar projetos de pesquisa. 4. Ed. São Paulo: Atlas.

GONZÁLEZ-BENITO, Óscar; MARTOS-PARTAL, Mercedes. Role of Retailer Positioning and Product Category on the Relationship Between Store Brand Consumption and Store Loyalty. Journal of Retailing. V. 88, n. 2, p. 236-249, 2012.

GOUVÊA, Maria Aparecida et al. Lealdade em compras online versus offline: reflexões sobre os fatores relevantes. Organizações \& Sociedade. V.20, n. 64, p. 37-53, 2013.

GREWAL, Dhruv et al. Does travel time to stores matter? The role of merchandise availability. Journal of Retailing. V. 88, n. 3, p. 437-444, 2012.

GUPTA, Shruti; PIRSCH, Julie. The influence of a retailer's corporate social responsibility program on re-conceptualizing store image. Journal of Retailing and Consumer Services. V. 15, n. 6, p. 516- 526, 2008.

HAIR JR., Joseph F. et al. (2005). Fundamentos de métodos de pesquisa em administração. (L. B. Ribeiro, Trad.). Porto Alegre: Bookman.

HERRBACH, Olivier et al. Exploring the role of perceived external prestige in managers' turnover intentions. The International Journal of Human Resource Management. V. 15, n. 8, p. 1390-1407, 2004.

HESSE-BIBER, Sharlene Nagy; LEAVY, Patricia. (Editors). (2004). Approaches to qualitative research: a reader on theory and practice. Oxford University Press.

HOMBURG, C. et al. When should the customer really be king? On the optimum level of salesperson customer orientation in sales encounters. Journal of Marketing. V. 75, n. 2, p. 55-74, 2011.

IJAZ, Muhammad Fazal et al. Efficient Digital Signage Layout as a Replacement to Virtual Store Layout. International Journal of Information and Electronics Engineering. V. 4, n. 4, p. 312-316, 2014.

JINFENG, Wu; ZHILONG, Tian. The impact of selected store image dimensions on retailer equity: Evidence from 10 Chinese hypermarkets. Journal of Retailing and Consumer Services. V. 16, n. 6, p. 486-494, 2009.

KAMARULZAMAN, Yusniza; LIH, Frankie Lee Chee. Attracting shoppers to shopping malls: the malaysian perspective. Interdisciplinary Journal of Contemporary Research in Business. V. 2, n. 3, p. 185-198, 2010.

KARIM, Jeannot Abdulet et al. Measuring shopping values of malaysian retail consumers. Asia Pacific Journal of Marketing and Logistics. V. 25, n. 2, p. 200-224, 2013. 
KIM, Young Hoon et al. A study of mobile user engagement (MoEN): engagement motivations, perceived value, satisfaction, and continued engagement intention. Decision Support Systems. V. 55, n. 1, p. 361-370, 2013.

KNOX, Simon D.; DENISON, Tim J. Store loyalty: its impact on retail revenue. An empirical study of purchasing behaviour in the UK. Journal of Retailing and Consumer Services. V. 7, n. 1, p. 33-45, 2000.

KOTLER, Philip; KELLER, Kevin Lane. (2006). Administração de marketing-12a ed. São Paulo: Pearson Prentice Hall.

KUO, Ren .J. et al. A decision support system for selecting convenience store location through integration of fuzzy AHP and artificial neural network. Computers in Industry. V. 47, n. 2, p. 199-214, 2002.

KUO, Ying-Feng et al. The relationships among service quality, perceived value, customer satisfaction, and post-purchase intention in mobile value-added services. Computers in Human Behavior. V. 25, n. 4, p. 887-896, 2009.

KUSUMOWIDAGDO, Astrid et al. Visitors' perception towards public space in shopping center in the creation sense of place. Procedia -Social and Behavioral Sciences. V.84, p. 266-272, 2015.

MARCONI, Marina de Andrade; LAKATOS, Eva Maria. Fundamentos de metodologia científica. 7. ed. São Paulo: Atlas, 2010.

LAM, Shun Yin. The effects of store environment on shopping behaviors: a critical review. Advances in Consumer Research. V.28, n. 1, p. 190-197, 2001.

LEE, Ming-Shing et al. The study of the relationship among experiential marketing, service quality, customer satisfaction and customer loyalty. International Journal of Organizational Innovation. V. 3, n.2, p. 352-378, 2010.

LEVY, M. L.; WEITZ, B. A. Retailing management. (2012). (Boston: McGraw-Hill).

LEWIS, Barbara R.; SOURELI, Magdalini. The antecedents of consumer loyalty in retail banking. Journal of Consumer Behaviour. V. 5, n. 1, p. 15-31, 2006.

MAJUMDAR, Aveek. A model for customer loyalty for retail stores inside shopping mallsan indian perspective. Journal of Services Research. P. 47-64, 2005. 
MARTENSON, Rita. Corporate brand image, satisfaction and store loyalty: A study of the store as a brand, store brands and manufacturer brands. International Journal of Retail \& Distribution Management. V. 35, n. 7, p. 544-555, 2007.

MARTINS, Gilberto Andrade; THEÓPHILO, Carlos Renato. (2009). Metodologia da investigação científica para ciências sociais aplicadas. $2^{\mathrm{a}}$ ed. São Paulo: Atlas.

MCDOUGALL, G.H.G; Levesque, T. Customer satisfaction with services: putting perceived value into the equation. Journal of Services Marketing. V. 14, n. 5, p. 392-410, 2010.

MOHAN, Geetha et al. Impact of store environment on impulse buying behavior. European Journal of Marketing. V. 47, n. 10, p. 1711-1732, 2013.

MOHAN, Geetha et al. Store environment's impact on variety seeking behavior. Journal of Retailing and Consumer Services. V. 19, n. 4, p. 419-428, 2012.

MOLINER, Miguel A. et al. Perceived relationship quality and post-purchase perceived value. European Journal of Marketing. V. 41, n. 11/12, p. 1392-1422, 2007.

MORRIN, Maureen; CHEBAT, Jean-Charles. Person-place congruency: the interactive effects of shopper style and atmospherics on consumer expenditures. Journal of Service Research. V. 8, n. 2, p. 181-191, 2005.

MOUSAVI, Seyed Mohsen; NIAKI, Seyed Taghi Akhavan. Capacitated location allocation problem with stochastic location and fuzzy demand: a hybrid algorithm. Applied Mathematical Modelling. V.37, n. 7, p. 5109-5119, 2013.

NEAL, W. D. Satisfaction is nice, but value drives loyalty. Marketing Research. V. 11, n.1, p. 20-23, 1999.

OMAR, N. A. et al. Program benefits, satisfaction and loyalty in retail loyalty program: exploring the roles of program trust and program commitment. Journal of Marketing Management. V. 9, n. 4, p. 6-28, 2010.

ORTH, Ulrich R.; GREEN, Mark T. Consumer loyalty to family versus non-family business: The roles of store image, trust and satisfaction. Journal of Retailing and Consumer Services. V. 16, n. 4, p. 248-259, 2009.

PATEL, Vipul; SHARMA, Mahendra .Consumers' motivations to shop in shopping malls: a study of indian shoppers. Asia-Pacific Advances in Consumer Research. V.8, p. 285-290. Sridhar Samu; Rajiv Vaidyanathan; Dipankar Chakravarti. (eds.). Duluth, MN. Association for Consumer Research. 
PETRICK, James F. Development of a multi-dimensional scale for measuring the perceived value of a service. Journal of Leisure Research. V. 34, n. 2, p.119-134, 2002.

QUARTIER, Katelijn; VAN CLEEMPOEL, Koenraad. Part of working paper, presented at the EDRA08 conference: Movement and Orientation in Built Environments, Vera Cruz, Mexico, 28 May 2008.

RABBANEE, Fazlul K. et al. Effects of store loyalty on shopping mall loyalty. Journal of Retailing and Consumer Services. V. 19, n. 3, p. 271-278, 2012.

RAVALD, A; GRÖNROOS, C.H. The value concept and relationship marketing. European Journal of Marketing. V. 30, n. 2, p. 19-30, 1996.

RAY, I.; CHIAGOURIS, L. Customer retention: examining the roles of store affect and store loyalty as mediators in the management of retail strategies. Journal of Strategic Marketing. V. 17, n. 1, p. 1-20, 2009.

ROSENBAUM, Mark S. et al. Loyalty programs and a sense of community. Journal of Services Marketing. V. 19, n. 4, p. 222-233, 2005.

SÁNCHEZ, Javier et al. Perceived value of the purchase of a tourism product. Tourism Management. V. 27, n. 3, p. 394-409, 2006.

SÁNCHEZ-FERNÁNDEZ, Raquel; INIESTA-BONILLO, M. Ángeles. The concept of perceived value: a systematic review of the research. Marketing Theory. V. 7, n.4, p. 427451, 2007.

SAXE, R.; WEITZ, B. A. The SOCO scale: a measure of the customer orientation of salespeople. Journal of Marketing Research. V. 19, n. 3, p. 343-351, 1982.

SILVA, Tarsis Souza; GIRALDI, Janaina de Moura Engracia; TAMASHIRO, Helenita R. da Silva. Um estudo empírico sobre as dimensões da imagem de loja no varejo calçadista.

Revista de Gestão. V. 19, n. 1, p. 125-143, 2013.

SIRDESHMUKH, Deepak et al. Consumer trust, value, and loyalty in relational exchanges. Journal of Marketing. V. 66, n. 1, p. 15-37, 2002.

SNOJ, Boris et al. The relationships among perceived quality, perceived risk and perceived product value. Journal of Product \& Brand Management. V. 13, n. 3, p. 156-167, 2004.

SUMMERS, Teresa A.; HEBERT, Paulette R. Shedding some light on store atmospherics: influence of illumination on consumer behavior. Journal of Business Research, V. 54, n 2, p. 145-150, 2001. 
SWEENEY, Jillian C; SOUTAR, Geoffrey N. Consumer perceived value: the development of a multiple item scale. Journal of Retailing. V. 77, n. 2, p. 203-220, 2001.

SWIMBERGHE, K. et al. An exploratory investigation of the consumer religious commitment and its influence on store loyalty and consumer complaint intentions. The Journal of Consumer Marketing. V. 26, n. 5, p. 340-347, 2009.

TEAS, R.; AGARWAL, S. The effects of extrinsic product cues on consumers' perceptions of quality, sacrifice, and value. Journal of the Academy of Marketing Science. V.28, n. 2, p. 278-290, 2000.

TRIPATHI, Shalini. N. An analysis of customer-pull factors and the process of store loyalty. Paradigm. V. 13, n. 1, p. 91-103, 2009.

TURHAN, Gülden et al. Literature review on selection criteria of store location based on performance measures. Procedia - Social and Behavioral Sciences. V. 99, n. 6, p. 391-402, 2013.

VAN ROMPAY, Thomas J. L.et al. On store design and consumer motivation: spatial control and arousal in the retail context. Environment and Behavior. V. 44, n. 6, p. 800-820, 2012.

VERMA, Hemraj. Measuring store image: an empirical study in some selected apparel retail stores. Amity Management Review. V. 2, n. 2, p. 2-18, 2012).

VILNAI-YAVETZ, Iris. GILBOA, Shaked. The effect of servicescape cleanliness on customer reactions. Services Marketing Quarterly. V. 31, n. 2, p. 213-234, 2010.

VRECHOPOULOS, Adam P. et al. Virtual store layout: an experimental comparison in the context of grocery retail. Journal of Retailing. V. 80, n. 1, p. 13-22, 2004.

WAKEFIELD, Kirk L.; BAKER, Julie. Excitement at the mall: determinants and effects on shopping response. Journal of Retailing. V. 74, n. 4, p. 515-539, 1998.

WANG, Y., Lo, H. P., Yang, Y. An integrated framework for service quality, customer value, satisfaction: evidence from China's telecommunication industry. Information Systems Frontiers. V. 6, n. 4, p. 325-340, 2004.

WESTBROOK, Robert A. Sources of consumer satisfaction with retail outlets. Journal of Retailing. V. 57, n. 3, p. 68-85, 1981.

YANG, Z.; Peterson, R.T. Customer perceived value, satisfaction, and loyalty: the role of switching costs. Psychology \& Marketing. V. 21, n.10, p. 799-822, 2004. 
YU, Tun-Hsiang et al. Assessing the residential property tax revenue impact of a shopping center. Journal of Real Estate Finance \& Economics. V. 45, n 3, p. 604-621, 2012.

YU, Yyun Soon et al. Service quality, perceived value, customer satisfaction, and behavioral intention among fitness center members aged 60 years and over. Social Behavior \& Personality: An International Journal. V. 42, n. 5, p. 757-767, 2014.

ZEITHAML, V. A.. Consumer perceptions of price, quality, and value: a means-end model and synthesis of evidence. Journal of Marketing. V. 52, n. 3, p. 2-22, 1988.

ZHANG, T. et al. The value of it- enabled retailer learning: personalized product recommendations and customer store loyalty in electronic markets. Management Information Systems. V. 35, n. 4, p. 859-882, 2011. 
GLOSSÁRIO 


\section{APENNDICES \\ ROTEIRO DE ENTREVISTA}

1. Mariana compra regularmente e preferencialmente na mesma loja, além de recomendá-la para outras pessoas. Você se vê como a Mariana? Por quê?

2. Em sua opinião, a música-ambiente da loja é um benefício para o cliente?

3. Em sua opinião, a iluminação dentro da loja é um benefício para o cliente?

4. O layout de loja diz respeito à forma como os produtos, gôndolas e corredores são organizados. Também inclui a concepção do espaço e a alocação, o agrupamento e a colocação da mercadoria. Você acredita que o layout da loja é um benefício para seus clientes? Por quê?

5. Você acredita que a disponibilidade de mercadorias é um benefício relevante para o cliente optar por uma loja? Por quê?

6. Você acredita que a presença dos vendedores na loja é um fator relevante para sua decisão em comprar lá? 
7. A imagem corporativa está relacionada à impressão que os clientes têm sobre a qualidade das mercadorias e do nível dos serviços da loja (assistência técnica, garantia oferecida, política de trocas etc.). Você acredita que a imagem exerce alguma influência sobre a decisão de compra destes clientes?

8. Renato afirma que a loja $\mathrm{ABC}$ possui certo prestígio em função de seu tempo de existência no mercado. Você acredita que este prestígio é um elemento importante para se comprar nesta loja? Por quê?

9. Mariana afirma que o local dentro do shopping center onde a loja está situada tem uma influência sobre sua decisão em comprar naquela loja. Você pensa como Mariana? Sim ou não? Se sim, que locais seriam esses?

10. Paulo compra na loja "ABC" porque, na sua avaliação, os benefícios de loja obtidos (ambiente, imagem, prestígio e localização) são maiores do que os esforços prévios (monetários e não monetários) que ele tem para comprar lá. Você acredita que esta situação é capaz de tornar Paulo fiel à loja? 


\section{TEXTO PADRÃO DE E-MAIL ENVIADO PARA OS POTENCIAIS RESPONDENTES.}

Prezado Sr. (a)....

Meu nome é Francisco Cláudio Melo dos Santos. Sou aluno do curso de doutorado em Administração do programa de Pós-Graduação da Faculdade de Economia, Administração e Contabilidade da Universidade de São Paulo (FEA-USP), sob a orientação do prof. Dr. Celso Cláudio de Hildebrand e Grisi.

O foco da minha pesquisa é investigar o comportamento de compras dos clientes de lojas situadas em shopping centers. Os objetivos são, por um lado, descobrir se os atributos como imagem, prestígio, disponibilidade de mercadoria e a localização da loja dentro do shopping são percebidos por eles como benefícios não monetários e se, efetivamente, agregam-lhes valor. Por outro, saber se este valor percebido é um fator relevante para sua decisão em se fidelizar a certa loja.

Por meio deste, gostaria de lhe convidar a tomar parte nesta pesquisa, por meio de entrevista previamente agendada de acordo com as datas e horários que lhe sejam mais convenientes. Cumpre-me informá-lo (a) de que esta pesquisa visa somente a objetivos acadêmicos.

Em caso de dúvida, não hesite em me contatar, pois terei o imenso prazer em dirimi-la.

Att:

Francisco Cláudio Melo dos Santos (Doutorado, NUSP 7670536). 
ANEXOS

CRITÉRIO BRASIL, DE ACORDO COM A ABEP (2015).

\section{Cortes do Critério Brasil}

\begin{tabular}{|cc|}
\hline Classe & Pontos \\
\hline A & $45-100$ \\
\hline B1 & $38-44$ \\
\hline B2 & $29-37$ \\
\hline C1 & $23-28$ \\
\hline C2 & $17-22$ \\
\hline D-E & $0-16$ \\
\hline
\end{tabular}

\section{SISTEMA DE PONTOS}

\section{Variáveis}

\begin{tabular}{|l|c|c|c|c|c|}
\hline & \multicolumn{7}{c|}{ Quantidade } \\
\hline & $\mathbf{0}$ & $\mathbf{1}$ & $\mathbf{2}$ & $\mathbf{3}$ & $\mathbf{4}$ ou + \\
\hline Banheiros & 0 & 3 & 7 & 10 & 14 \\
\hline Empregados domésticos & 0 & 3 & 7 & 10 & 13 \\
\hline Automóveis & 0 & 3 & 5 & 8 & 11 \\
\hline Microcomputador & 0 & 3 & 6 & 8 & 11 \\
\hline Lava louca & 0 & 3 & 6 & 6 & 6 \\
\hline Geladeira & 0 & 2 & 3 & 5 & 5 \\
\hline Freezer & 0 & 2 & 4 & 6 & 6 \\
\hline Lava roupa & 0 & 2 & 4 & 6 & 6 \\
\hline DVD & 0 & 1 & 3 & 4 & 6 \\
\hline Micro-ondas & 0 & 2 & 4 & 4 & 4 \\
\hline Motocicleta & 0 & 1 & 3 & 3 & 3 \\
\hline Secadora roupa & 0 & 2 & 2 & 2 & 2 \\
\hline
\end{tabular}

Grau de instrução do chefe de família e acesso a serviços públicos

\begin{tabular}{|c|c|}
\hline \multicolumn{2}{|l|}{ Escolaridade da pessoa de referência } \\
\hline Analfabeto / Fundamental I incompleto & 0 \\
\hline Fundamental I completo / Fundamental II incompleto & 1 \\
\hline Fundamental II completo / Médio incompleto & 2 \\
\hline Médio completo / Superior incompleto & 4 \\
\hline Superior completo & 7 \\
\hline \multicolumn{2}{|l|}{ Serviços públicos } \\
\hline Não & Sim \\
\hline Água encanada & 4 \\
\hline Rua pavimentada & 2 \\
\hline
\end{tabular}




\section{PROCEDIMENTO NA COLETA DOS ITENS}

É importante e necessário que o critério seja aplicado de forma uniforme e precisa. Para tanto, é fundamental atender integralmente as definições $e$ procedimentos citados a seguir.

Para aparelhos domésticos em geral:

Devem ser considerados todos os bens que estão dentro do domicílio em funcionamento (incluindo os que estão guardados) independente da forma de aquisição: compra, empréstimo, aluguel, etc. Se o domicilio possui um bem que emprestou a outro, este não deve ser contado pois não está em seu domicílio atualmente. Caso não estejam funcionando, considere apenas se tiver intenção de consertar ou repor nos próximos seis meses.

\section{Banheiro}

o que define o banheiro é a existência de vaso sanitário. Considerar todos os banheiros e lavabos com vaso sanitário, incluindo os de empregada, os localizados fora de casa e os da(s) suíte(s). Para ser considerado, o banheiro tem que ser privativo do domicílio. Banheiros coletivos (que servem a mais de uma habitação) não devem ser considerados.

\section{Empregados Domésticos}

Considerar apenas os empregados mensalistas, isto é, aqueles que trabalham pelo menos cinco dias por semana, durmam ou não no emprego. Não esqueça de incluir babás, motoristas, cozinheiras, copeiras, arrumadeiras, considerando sempre os mensalistas.

Note bem: o termo empregado mensalista se refere aos empregados que trabalham no domicilio de forma permanente e/ou continua, pelo menos cinco dias por semana, e não ao regime de pagamento do salário.

\section{Automóvel}

Não considerar táxis, vans ou pick-ups usados para fretes, ou qualquer veículo usado para atividades profissionais. Veículos de uso misto (pessoal e profissional) não devem ser considerados.

\section{Microcomputador}

Considerar os computadores de mesa, laptops, notebooks e netbooks. Não considerar: calculadoras, agendas eletrônicas, tablets, palms, smartphones e outros aparelhos.

\section{Lava-Louça}

Considere a máquina com função de lavar as louças.

\section{Geladeira e Freezer}

No quadro de pontuação há duas linhas independentes para assinalar a posse de geladeira e freezer respectivamente. A pontuação será aplicada de forma independente:

Havendo uma geladeira no domicílio, serão atribuídos os pontos (2) correspondentes a posse de geladeira;

Se a geladeira tiver um freezer incorporado $-2^{a}$ porta - ou houver no domicílio um freezer independente serão atribuídos os pontos (2) correspondentes ao freezer. Dessa forma, esse domicilio totaliza 4 pontos na soma desses dois bens.

\section{Lava-Roupa}

Considerar máquina de lavar roupa, somente as máquinas automáticas e/ou semiautomática. $\mathrm{O}$ tanquinho NÃO deve ser considerado.

\section{$\underline{\text { DVD }}$}

Considere como leitor de DVD (Disco Digital de Vídeo ou Disco Digital Versátil) o acessório doméstico capaz de reproduzir mídias no formato DVD ou outros formatos mais modernos, incluindo videogames, computadores, notebooks. Inclua os aparelhos portáteis e os acoplados em microcomputadores. Não considere DVD de automóvel.

\section{Micro-ondas}

Considerar forno micro-ondas e aparelho com dupla função (de micro-ondas e forno elétrico).

\section{Motocicleta}

Não considerar motocicletas usadas exclusivamente para atividades profissionais. Motocicletas apenas para uso pessoal e de uso misto (pessoal e profissional) devem ser consideradas.

\section{Secadora de roupas}

Considerar a máquina de secar roupa. Existem máquinas que fazem duas funções, lavar e secar. Nesses casos, devemos considerar esse equipamento como uma máquina de lavar e como uma secadora. 


\section{Modelo de Questionário sugerido para aplicacão}

P.XX Agora vou fazer algumas perguntas sobre itens do domicilio para efeito de classificação econômica. Todos os itens de eletroeletrônicos que vou citar devem estar funcionando, incluindo os que estão guardados. Caso não estejam funcionando, considere apenas se tiver intenção de consertar ou repor nos próximos seis meses.

\section{INSTRUÇÃO: Todos os itens devem ser perguntados pelo entrevistador e respondidos pelo entrevistado. \\ Vamos começar? No domicílio tem (LEIA CADA ITEM)}

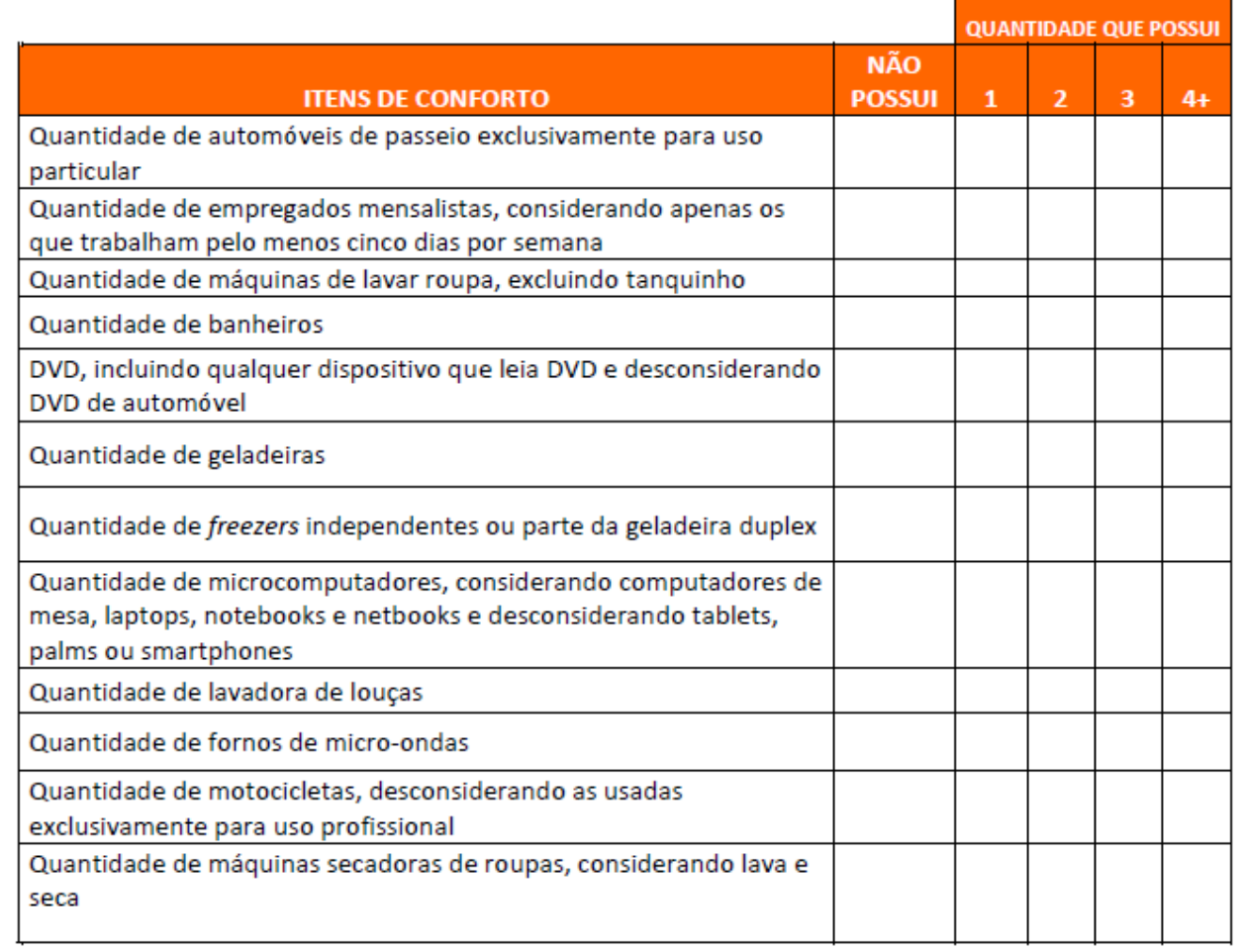

\begin{tabular}{|c|l|}
\hline A água utilizada neste domicílio é proveniente de? \\
\hline 1 & Rede geral de distribuição \\
\hline 2 & Poço ou nascente \\
\hline 3 & Outro meio \\
\hline
\end{tabular}

\section{Considerando o trecho da rua do seu domicílio, você diria que a rua é:}

\begin{tabular}{|c|l|}
\hline 1 & Asfaltada/Pavimentada \\
\hline 2 & Terra/Cascalho \\
\hline
\end{tabular}

